\title{
303-K Storage Facility: Report on FY98 Closure Activities
}

Prepared for the U.S. Department of Energy

RWOR DANHEL HANFORd, unc. Richland, Washington

Hanford Management and Integration Contractor for the

U.S. Department of Energy under Contract DE-ACO6-96RL13200 


\section{3-K Storage Facility: Report on FY98 Closure Activities}

Date Published

July 1998

Prepared for the U.S. Department of Energy

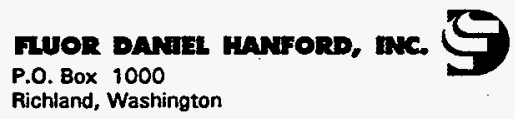

Hanford Mansgement and Integration Contractor for the U.S. Department of Energy under Contrect DE-ACO6-96RL13200 


\section{RELEASE AUTHORIZATION}

Document Number: HNF-2959, Revision 0

$\begin{array}{ll} & 303-K \text { Storage Facility: } \\ \text { Document Title: } & \text { Report on FY } 98 \text { Closure Activities }\end{array}$

This document, reviewed in accordance with DOE Order 1430.1D, "Scientific and Technical Information Management," and DOE G 1430.1D-1, "Guide to the Management of Scientific and Technical Information," does not contain classified or sensitive unclassified information and is:

APPROVED FOR PUBLIC RELEASE

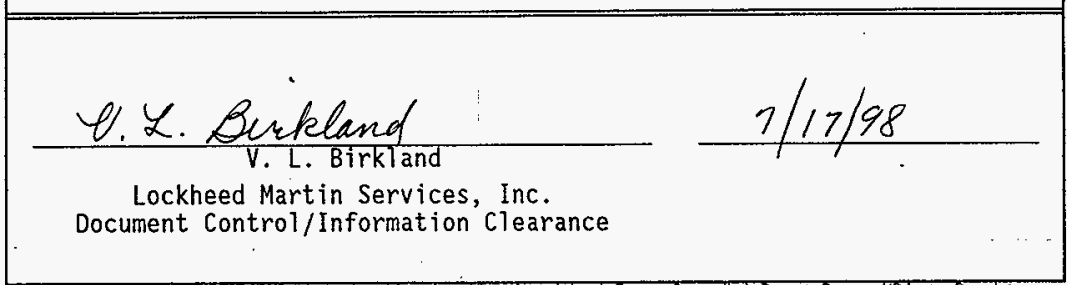

Reviewed for Applied Technology, Business Sensitive, Classified, Copyrighted, Export Controlled, Patent, Personal/Private, Propnetary, Protected CRADA, Trademark, Unclassified Controlled Nuclear Information.

Trademark Disclaimer. Reference herein to any specific commercial product, process, or service by trado namo, trademark, manufacturer, or otherwise, does not necessarily constitute or imply its endorsement, recommendation, or favoring by the United States Government or any agency thereof or its contractors or subcontracters. The views and opinions of authors expressed herein do not nocessarily state or refiect those of the United States Government or any sgency thereof. This report has been reproduced from the best available copy.

Printed in the United States of America.

Available to the U.S. Department of Energy and its contractors from the U.S. Department of Energy Office of Scientific and Technical Information, P.O. Box 62, Ook Ridge. TN 37831: Telephone: 423/576-8401.

Aveilable to the public from the U.S. Department of Commerce National Technicat Infomation Service, 5285 Port Royal Road. Springfield, VA 22161: Telephone: 703/487.4650. 


\section{CONTENTS}

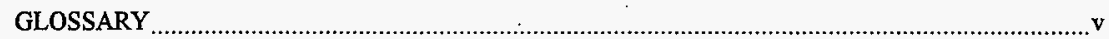

$1.0 \quad$ INTRODUCTION

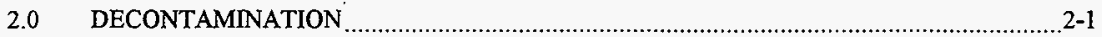

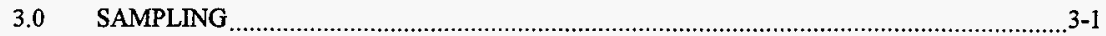

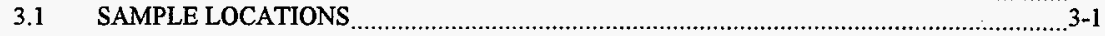

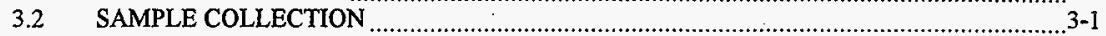

$12 \quad 3.2 .1$ Interior (Concrete) Sample Collection ......................................................................... 3-1

$13 \quad 3.2 .2$ Exterior (Soil) Sample Collection .................................................................................

$14 \quad 3.3$ FIELD QUALITY ASSURANCE AND QUALITY CONTROL ……................................ $3-3$

$16 \quad 4.0 \quad$ FIELD SCREENING FOR PENTACHLOROPHENOL _.................................................. $4-1$

$17 \quad 4.1$ FIELD SCREENING KIT METHODOLOGY

$18 \quad 4.2 \quad$ FIELD SCREENING RESULTS

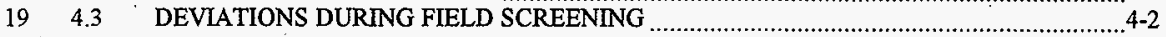

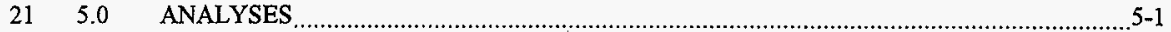

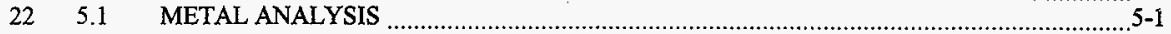

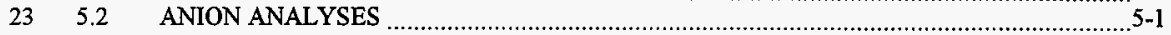

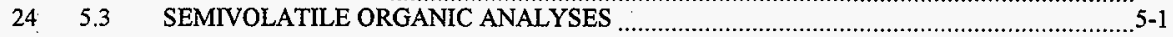

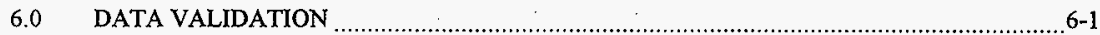

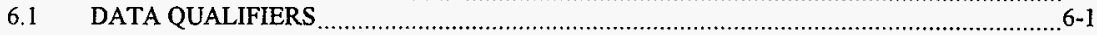

6.2 EXPLANATION OF QUALIFIED DATA

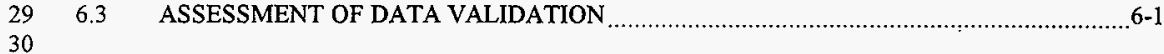

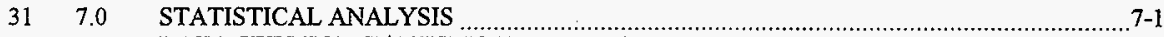

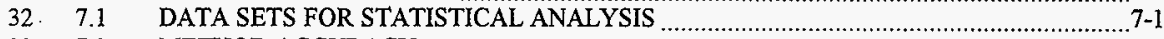

$33 \quad 7.2$ METHOD ACCURACY

$34 \quad 80$ DATA EVALUATION

$36 \quad 8.1$ EVALUATION OF THE INTERIOR CONCRETE SAMPLE DATA

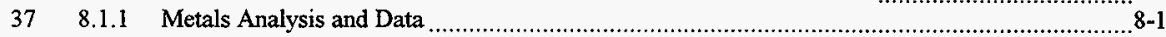

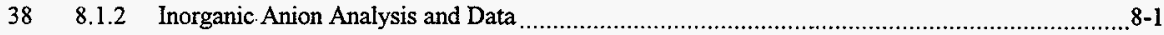

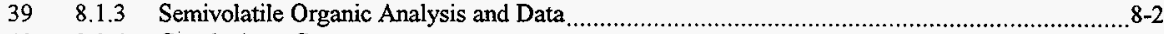

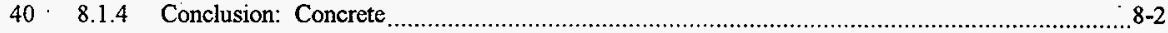

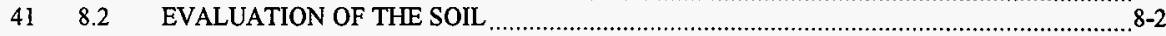

$42 \quad 8.2 .1 \quad$ Metals Analysis and Data

$43 \quad 8.2 .2$ Semivolatile Organic Analysis and Data ............................................................................ 8 -3

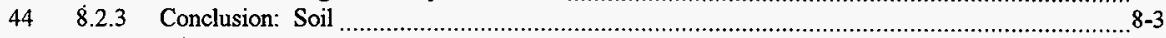

$45 \quad 8.3 \quad$ EQUIPMENT AND FIELD BLANK ANALYTICAL RESULTS ……................................. $8-3$

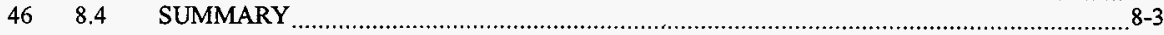


HNF-2959

CONTENTS (cont)

9.0 CONCLUSIONS $9-1$

10.0 REFERENCES 10-1

\section{APPENDICES}

$\begin{array}{ll}\text { A } & \text { SAMPLER'S FIELD LOG } \\ \text { B } & \text { ECOLOGY SPLIT SAMPE DATA } \\ \text { C } & \text { FIELD CHANGE AGREEMENT } \\ \text { D } & \text { IMMUNOASSAY KIT INSTRUCTIONS } \\ \text { E } & \text { EQUATIONS USED IN THE STATISTICAL ANALYSIS }\end{array}$

\section{FIGURES}

Figure 1-1. 303-K Storage Facility Boundary. $1-3$

Figure 3-1. 303-K Storage Facility Concrete Sampling Locations (Trench). ......................................... 3-4

Figure 3-2. 303-K Storage Facility Concrete Sampling Location (Ceiling). ........................................ 3-5

Figure 3-3. 303-K Storage Facility Soil Sample Locations. .................................................. 3-6

\section{TABLES}

Table 1-1. Soil and Concrete Cleanup Performance Standards for the Constituents of Concern. ............ 1-2

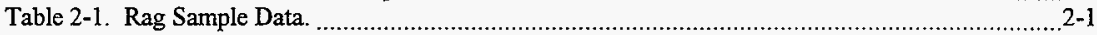

Table 3-1. 303-K Storage Facility Sampling Locations. .................................................................. 3-7

Table 3-2. 303-K Storage Facility: Sampling and Analysis Summary for Interior Samples. ....................3-8

Table 3-3. 303-K Storage Facility: Sampling and Analysis Summary for the Exterior Samples..............3-9

Table 3-4. Summary and Cross-Reference of Sample Numbers to Sample Information. .......................3-10

Table 3-5. Summary and Cross-reference of Sample Locations to Sample Numbers. ............................3-11

Table 3-6. Sampling Container Information. ........................................................................... 3-12

Table 4-1. Results from the Field Screening for Pentachlorophenol. ..............................................4-3

Table 5-1. Constituents of Concern, Sample Media, and Analytical Methods.

Table 5-2. Interior Sampling Data Summary. .................................................................. 5-3

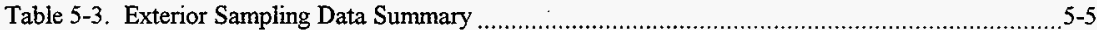

Table 6-1. Data Qualifications Summary Table.......................................................................6-3

Table 7-1. Exterior (Soil) Data Statistical Analysis.

Table 7-2. Interior (Concrete) Data Statistical Analysis. ............................................................... $7-3$

Table 8-1. Comparison Of Method Detection Limit and Method Quantitation Limit Requirements......... 8-5 
HNF-2959

1

2 DOE/RL

3

4 EPA

5

6 HNF

- 7

8 RCRA

9

10 SAP

11

12 Tri-Party Agreement

13

14 WAC

15

\section{GLOSSARY}

U.S. Department of Energy, Richland Operations Office

U.S. Environmental Protection Agency

Hanford Nuclear Facility (document identifier)

Resource Conservation and Recovery Act (RCRA) of 1976

sampling analysis plan

Hanford Federal Facility Agreement and Consent Order

Washington Administrative Code 
HNF-2959

1

2

3

4

5

This page intentionally left blank. 


\subsection{INTRODUCTION}

This report summarizes and evaluates the decontamination activities, sampling activities, and sample analysis performed in support of the closure of the 303-K Storage Facility (Figure 1-1). The evaluation is based on the validated data included in the data validation package (98-EAP-346) for the 303-K Storage Facility. The results of this evaluation will be used in assessing contamination for the purpose of closing the 303-K Storage Facility as described in the 303-K Storage Facility Closure Plan, DOE/RL-90-04.

The closure strategy for the 303-K Storage Facility is to decontaminate the interior of the north half of the 303-K Building to remove known or suspected dangerous waste contamination, to sample the interior concrete and exterior soils for the constituents of concern, and then to perform data analysis, with an evaluation to determine if the closure activities and data meet the closure criteria. The closure criteria for the 303-K Storage Facility is that the concentrations of constituents of concern are not present above the cleanup levels.

Based on the evaluation of the decontamination activities, sampling activities, and sample data, determination has been made that the soils at the $303-\mathrm{K}$ Storage Facility meet the cleanup performance standards (WMH 1997) and can be clean closed. The evaluation determined that the 303-K Building cannot be clean closed without additional closure activities:

An additional evaluation will be needed to determine the specific activities required to clean close the 303-K Storage Facility.

The radiological contamination at the $303-\mathrm{K}$ Storage Facility is not addressed by the closure strategy. The Hanford Federal Facility Agreement and Consent Order (Tri-Party Agreement) allows for the closing of treatment, storage, and/or disposal (TSD) units even when radiological contamination is present.

Radiological contamination and uranium are not regulated under RCRA. The information on uranium has been included for information purposes only.

There are two documents that define the decontamination, sampling and analysis requirements for the 303-K Storage Facility: DOE/RL-90-04 and 303-K Storage Facility Sampling and Analysis Plan (HNF-SD-ENV-AP-005). The sampling and analysis plan was developed during the data quality objectives process of November 1996 to May 1997.

The sampling and analysis plan defines the following: constituents of concern, cleanup performance standards, cleanup activities, sampling locations and methods, field screening locations and methods, field quality control requirements, laboratory analytical methods, and data validation methodology. Also, at the time sampling was conducted, the sampling and analysis plan was modified by:

- The errata sheet for the 303-K Storage Facility Sampling and Analysis Plan (DOE-RL 1997)

- Dangerous Waste Portion of the Resource Conservation and Recovery Act Permit for the Treatment, Storage, and Disposal of Dangerous Waste [Hanford Facility RCRA Permit (HF RCRA Permit)] (Ecology 1994); Part V, Chapter 14, Permit Conditions V.14.B.b, V.14.B.c

- Hanford RCRA Permit, Draft Permit Conditions V.14.B.g.1, V.14.B.g.3, V.14.B.g.4, V.14.B.g.5, and V.14.B.g.7. (Ecology letter 9757627A) 
1

For simplicity and clarity, 'modified sampling and analysis plan (SAP)' will be used to refer to the sampling and analysis plan and these three modifying documents. If there is a conflict in the requirements stated in the closure plan and the modified SAP, the closure plan is superseded by the modified SAP. Use of the modified SAP had been required by Ecology (Ecology letter 9757627A) as part of the approval process.

The specific constituents of concern and their cleanup performance standards to be used for the closure of the 303-K Storage Facility were defined in the modified SAP. The cleanup performance standards for the constituents of concern are summarized in Table 1-1.

Table 1-1. Soil and Concrete Cleanup Performance Standards for the Constituents of Concern

\begin{tabular}{|l|c|c|}
\hline \multicolumn{1}{|c|}{ Constituent of concern } & CAS number & Cleanup level (mg/kg) \\
\hline Arsenic & $7440-38-2$ & 9.18 \\
\hline Barium & $7440-39-3$ & 5,600 \\
\hline Beryllium & $7440-41-7$ & 1.81 \\
\hline Cadmium & $7440-43-9$ & 80 \\
\hline Chromium & $7440-47-3$ & 400 \\
\hline Lead & $7439-92-1$ & 250 \\
\hline Mercury & $7439-97-5$ & 24 \\
\hline Nickel (as soluble salts) & $7440-02-0$ & 1,600 \\
\hline Silver & $7440-22-4$ & 400 \\
\hline Uranium & $7440-61-1$ & $\mathrm{n} / \mathrm{a}$ \\
\hline Chloride ion (CL) & $\mathrm{n} / \mathrm{a}$ & 541.2 \\
\hline Nitrate ion ( $\mathrm{NO}_{3}$ ) & $14797-55-8$ & 128,000 \\
\hline Nitrite ion (NO ${ }_{2}$ ) & $14797-65-0$ & 8,000 \\
\hline Pentachlorophenol & $87-86-5$ & 8.33 \\
\hline
\end{tabular}

n/a not applicable or not available

$\mathrm{mg} / \mathrm{kg}$ milligrams per kilogram

CAS Chemical Abstract Service. 
HNF-2959

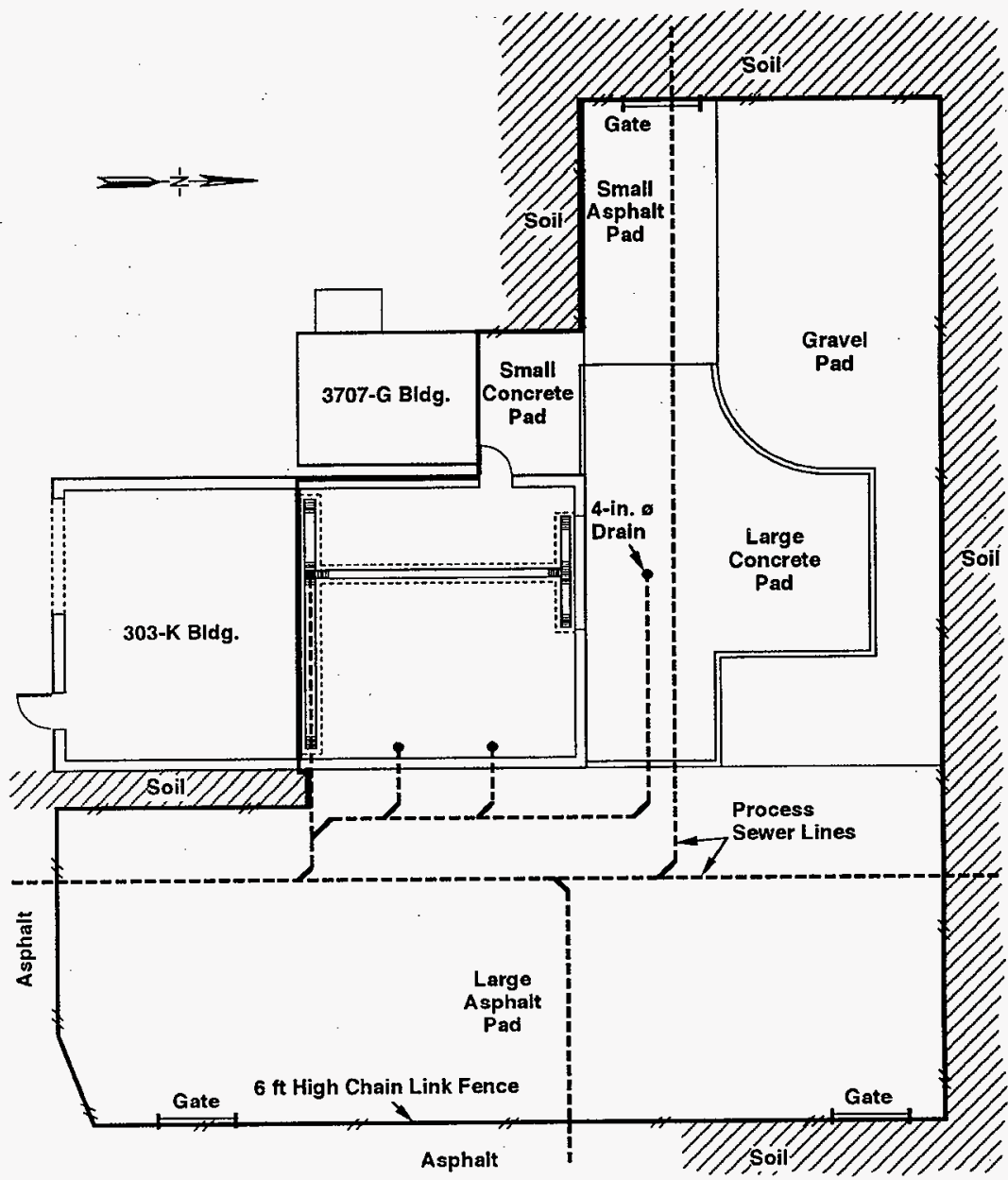

Treatment, Storage, and Disposal Unit Boundary

Not to Scale

H97040048.2

Figure 1-1. 303-K Storage Facility Boundary. 
HNF-2959

1

2

3

4

5

This page intentionally left blank. 


\subsection{DECONTAMINATION}

2 The decontamination effort followed the requirements of the closure plan and the modified SAP. The

3 decontamination effort at the $303-\mathrm{K}$ Storage Facility addressed only the dangerous waste constituents of 4 concern.

5

Decontamination for dangerous waste constituents was performed on October 23,1997 . In accordance with the modified SAP, the decontamination was limited to damp-wiping the floor and interior trenches. Rags used in the decontamination were sampled; results are included in Table 2-1.

Table 2-1. Rag Sample Data.

\begin{tabular}{|c|c|c|c|c|c|}
\hline \multicolumn{6}{|c|}{ Sample Number: BOMHV5 } \\
\hline Analyte & \multicolumn{2}{|c|}{ Method } & \multicolumn{2}{|c|}{ Result (mg/kg) } & $\mathrm{MDL}(\mathrm{mg} / \mathrm{kg})$ \\
\hline Arsenic & GFAA & LA-505-450 & 0.00 & $\mathrm{U}$ & 1.00 \\
\hline Barium & ICP & EPA 6010A & 22.5 & & 0.40 \\
\hline Beryllium & $\mathrm{ICP}$ & EPA $6010 A$ & $<0 . \overline{403}$ & $\mathrm{U}$ & 0.40 \\
\hline Cadmium & ICP & EPA $6010 A$ & 1.51 & & 0.50 \\
\hline Chromium & ICP & EPA $6010 A$ & 13.5 & $\mathrm{~J}$ & 0.50 \\
\hline Lead & GFAA-CLP & LA- $505-405$ & 450 & $\mathbf{J}$ & 0.80 \\
\hline Mercury & Cold vapor & LA-505-404 & 0.03 & $\mathbf{J}$ & 0.12 \\
\hline Nickel & $\mathrm{ICP}$ & EPA $6010 \mathrm{~A}$ & 1.69 & $\mathrm{~J}$ & 1.11 \\
\hline Silver & $\mathrm{ICP}$ & EPA 6010A & 3.12 & $\bar{J}$ & 0.40 \\
\hline Uranium & ICP-MS & EPA 200.8 & 2780 & & 0.30 \\
\hline Chloride ion & IC & LA-533-410 & 58.5 & & 10.60 \\
\hline Nitrate ion & $\mathrm{IC}$ & LA-533-410 & 1.8 & $J$ & 0.78 \\
\hline Nitrite ion & IC & LA-533-410 & 0.2 & $\mathrm{U}$ & 0.20 \\
\hline Pentachlorophenol & GC-MS & EPA $8270 B$ & 0.0 & $\bar{U}$ & 390.0 \\
\hline
\end{tabular}

$$
\begin{array}{ll}
\text { EPA } & =\text { U.S. Environmental Protection Agency method number } \\
\text { GC-MS } & =\text { gas chromatography - mass spectrometer }
\end{array}
$$$$
\text { GFAA = gas fumace atomic absorption }
$$$$
\text { GFAA-CLP = gas furnace atomic absorption }
$$$$
\text { IC = ion chromatography }
$$$$
\text { ICP = ion coupled plasma }
$$$$
\text { ICP-MS = ion coupled plasma }- \text { mass spectrometer }
$$

$\mathrm{J} \quad=$ Indicates that the compound or analyte was analyzed for and detected, but the value is an estimate.

LA-xxx- $\mathrm{xxx}=$ Waste Sampling and Characterization Facility laboratory procedure number

MDL = method detection limit

$$
\mathrm{mg} / \mathrm{kg} \quad=\text { milligrams per kilograms }
$$

$$
\text { U }
$$

= Indicates that the compound or analyte was analyzed for and not detected in the sample. The value reported is the sample quantitation limit corrected for sample dilution and moisture content. 
HNF-2959

1

2

3

4

5

This page intentionally left blank. 


\subsection{SAMPLING}

Sampling took place on October 29 and 30, 1997. Sampling was conducted in accordance with the closure plan and the modified SAP. There were 15 sampling locations: 3 in the interior of the 303-K Building and 12 in the exterior areas. At three of the soil sampling locations, samples were collected at two separate intervals. Sampling media were concrete for the interior sample locations and soil for the exterior sample locations. A total of 25 samples were collected: 17 routine samples and 8 quality control samples (5 duplicates and 3 equipment blanks).

\subsection{SAMPLE LOCATIONS}

The sample locations were established in the modified SAP. Figures 3-1 through 3-3 and Tables 3-1 through 3-3 provide a summary of the sample locations and sample types. Tables 3-4 and 3-5 provides cross-reference lists of sample numbers to sample location.

\subsection{SAMPLE COLLECTION}

Samples were collected at the locations defined in Section 3.1. Sample collection methodology is defined in the modified SAP. Any deviations or field changes are noted in the following sections. Separate containers were used for the different analysis. Sampler's log book entries are included in Appendix A. Split samples also were collected for Ecology. A copy of Ecology's data is included in Appendix B.

\subsubsection{Interior (Concrete) Sample Collection}

There are three sample locations in the interior: two in the trench and one on the ceiling (Figures 3-1 and 3-2 and in Table 3-1). Three concrete samples were collected from the interior, and one concrete duplicate sample was collected in the trench at sample location C2, for a total of four concrete samples from the interior. All interior sampling was conducted on October 30, 1997.

The bottles used for the collection of samples were vendor certified to U.S. Environmental Protection Agency (EPA) Level 1. The size, type, lot number, and analysis are identified on Table 3-6. The sample for the radiological analysis used a 20 milliliter poly bottle and did not have or require lot or serial number.

The concrete samples were collected using an electrically operated heavy-duty hammer. Concrete dust and small chips were generated by chiseling and scabbling. With sample location $\mathrm{C} 3$ being on the ceiling of the north half of the 303-K Building, a plastic sheet was taped to the ceiling to collect the chips and dust. The dust and chips were collected in sample jars and shipped to LAS, Inc. in Las Vegas, Nevada. All samples were cooled to $4^{\circ}$ Celsius for storage and transportation.

\subsubsection{Deviation During the Interior (Concrete) Sampling}

One deviation from the modified SAP occurred during collection of the interior samples. The deviation was use of hardened steel chisels instead of tungsten carbide chisels. 


\subsubsection{Field Changes During the Interior (Concrete) Sampling}

There were two field changes to the modified SAP during the interior sampling. Agreement to the field change by Ecology is documented in Appendix C. The field changes were the following:

- At sample location $\mathrm{C} 2$, because of the large area of concrete that needed to be scabbled, there was insufficient room to collect a duplicate sample from an adjacent location. Therefore, $\mathrm{C} 2$ duplicate sample was collected from the same material as the $\mathrm{C} 2$ sample.

- A sample for laboratory analysis of pentachlorophenol was taken from location $\mathrm{Cl}$. This was the result of the field screening that yielded inconsistent results. Refer to Section 4.0 for additional information.

\subsubsection{Exterior (Soil) Sample Collection}

There were 12 exterior sample lacations that yielded 18 soil samples (Figure 3-3 and in Table 3-1). Single samples were collected at 10 locations. Separate samples from upper and lower intervals were collected at three locations. Fourteen exterior routine soil samples and four duplicate samples were collected. Soil sampling occurred on October 29 and 30, 1997.

The bottles used for the collection of samples were vendor certified to EPA Level 1. The size, type, lot number, and analysis are identified on Table 3-6. The sample for the radiological analysis used a 20 milliliter poly bottle and did not have or require lot or serial number.

The soil samples were collected using an electrically operated heavy-duty hammer to open a hole in the asphalt or concrete. The top layer of soil material was removed and a hand auger or a spoon was used to transfer the soil material into a stainless steel bowl. Rocks and pebbles were excluded at this time. From the bowl, the soil samples were collected in the sample containers. Poly containers were used for the metals and anion samples and amber glass containers were used for the semivolatile organic soil samples. All soil samples were shipped to LAS, Inc. in Las Vegas, Nevada. All samples were cooled to $4^{\circ}$ Celsius for storage and transportation.

There were the following three field changes to the modified SAP during the exterior sampling. Ecology agreement to the field changes is documented in Appendix $\mathrm{C}$.

- Sample location S7 was moved east (about 0.3 meter) from outside the fence to inside the fence. The original sample location was in the dirt strip between the fence and the wall of the south half of the $303-\mathrm{K}$ Building. The move was prompted by concerns about possible radiological contamination in the soil.

- Sample location $\$ 10$ was relocated about 0.45 meter south and 0.15 meter east of the original location selected. This sample was relocated because rain water collected in the original sample hole.

- Samples for laboratory analysis of pentachlorophenol were taken from all soil sampling locations. This was the result of the field screening that yielded inconsistent results. Refer to Section 4.0 for additional information. 


\subsection{FLEL QUALITY ASSURANCE AND QUALITY CONTROL}

The modified SAP required only one type of field quality assurance and quality control sample, equipment blanks, to be collected during the sampling. The modified SAP required one equipment blank be collected for each type of sampling equipment per day of sampling. The equipment blanks were collected using deionized water transported to the sampling site. At the site, the deionized water was poured over or through the sample collection device, collected, and sent to the offsite analytical laboratory for analysis. A total of three equipment blanks were collected and analyzed. There were two soil sampling equipment blanks with one each being collected on October 29 and 30, 1997. There was one concrete chip sampling equipment blank collected on October 30, 1997. 
HNF-2959

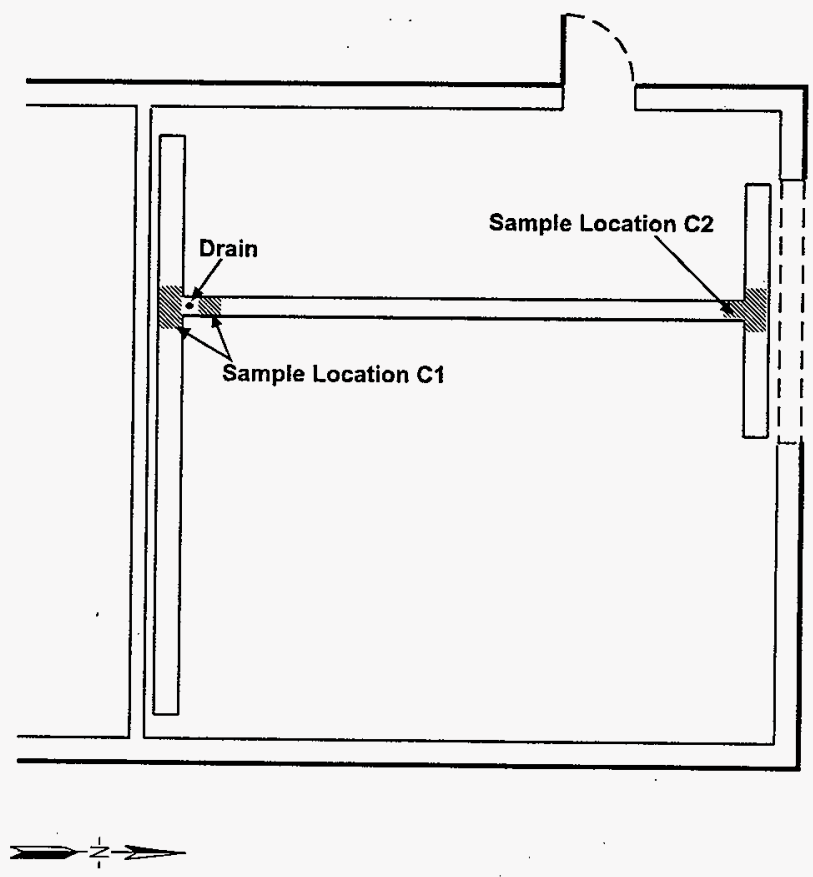

Concrete Sample Location

H97040048.3

Figure 3-1. 303-K Storage Facility Concrete Sampling Locations (Trench). 
HNF-2959

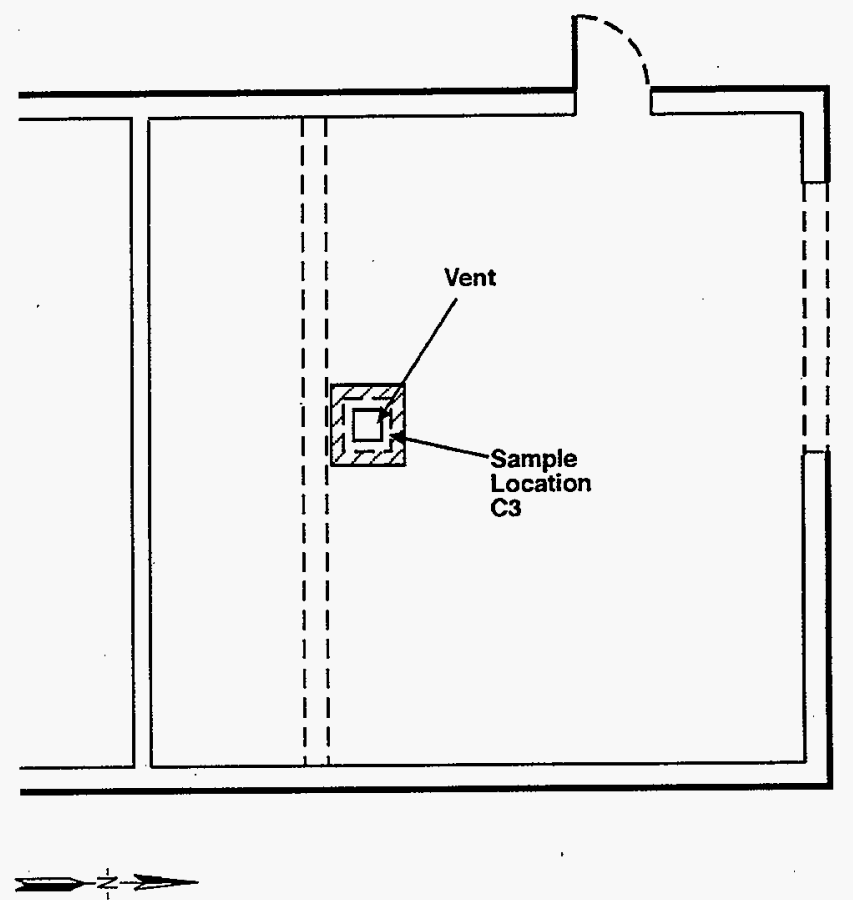

H97040048.4

Figure 3-2. 303-K Storage Facility Concrete Sampling Location (Ceiling). 
HNF-2959

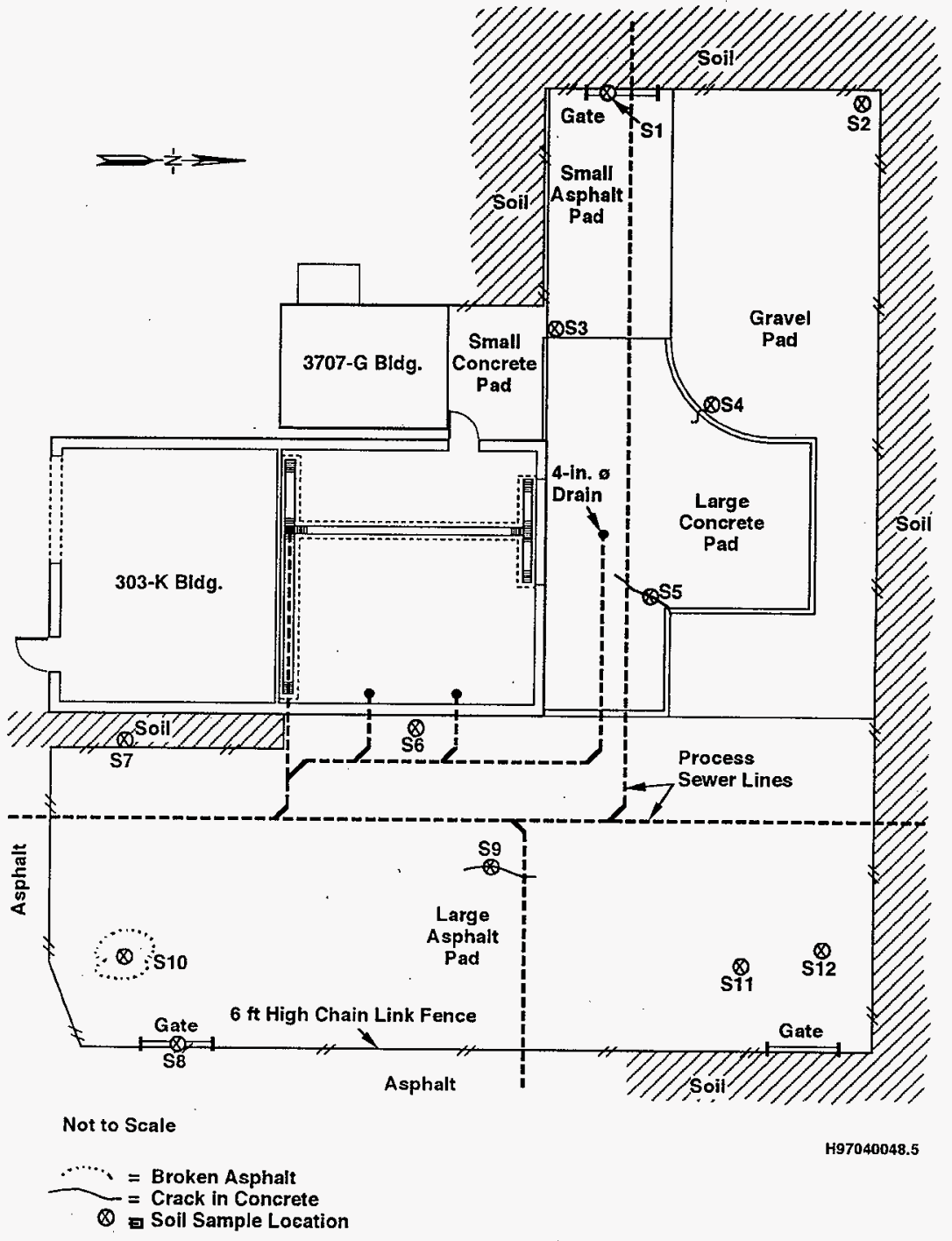

Figure 3-3. 303-K Storage Facility Soil Sample Locations. 
Table 3-1. 303-K Storage Facility Sampling Locations.

\begin{tabular}{|c|c|c|}
\hline Sample Types & Sample Location & Description of the Sample Location \\
\hline \multirow[t]{3}{*}{ CONCRETE SAMPLES } & $\mathrm{Cl}$ & South Trench Junction Near Drain \\
\hline & $\mathrm{C} 2$ & North Trench Junction \\
\hline & $\mathrm{C} 3$ & Ceiling Near Vent \\
\hline \multirow[t]{12}{*}{ SOIL SAMPLES } & Sl & $\begin{array}{l}\text { Center of west gate at the end of the Small Asphalt } \\
\text { Pad }\end{array}$ \\
\hline & S2 & $\begin{array}{l}\text { North-west corner of the Gravel Pad, about } 1 \text { meter } \\
\text { from each fence line }\end{array}$ \\
\hline & S3 & $\begin{array}{l}\text { South-east corner of the Small Asphalt Pad, about } \\
0.3 \text { meter from each edge }\end{array}$ \\
\hline & $\$ 4$ & $\begin{array}{l}\text { On the Gravel Pad, adjacent to the large crack on the } \\
\text { north-west curved berm of the Large Concrete Pad. } \\
\text { This is the large crack furthest from the building. }\end{array}$ \\
\hline & S5 & $\begin{array}{l}\text { On the crack in the Large Concrete pad, north-east of } \\
\text { the drain }\end{array}$ \\
\hline & S6 & $\begin{array}{l}\text { On the Large Asphalt Pad, adjacent to the } \\
303-K \text { Building and between the sink and wash-basin } \\
\text { drains }\end{array}$ \\
\hline & S7 & $\begin{array}{l}\text { In the soil between the south-west edge of the Large } \\
\text { Asphalt Pad and the south-half of the } 303-\mathrm{K} \text { Building, } \\
\text { with the sample location adjacent to the Large concrete } \\
\text { pad and about } 2 \text { meters north of the south-west corner } \\
\text { of the Large Asphalt Pad. }\end{array}$ \\
\hline & S8 & $\begin{array}{l}\text { On the edge of the Large Asphalt Pad and in the center } \\
\text { of the south-east gate. }\end{array}$ \\
\hline & s9 & $\begin{array}{l}\text { On the Large Asphalt Pad, on a crack in the } \\
\text { approximate center of the pad }\end{array}$ \\
\hline & $\mathrm{S} 10$ & $\begin{array}{l}\text { In the south-east quadrant of the Large Asphalt Pad } \\
\text { and one the area of deteriorating asphalt }\end{array}$ \\
\hline & S1l & $\begin{array}{l}\text { In the north east quadrant of the Large Asphalt Pad, } \\
\text { about } 3 \text { meters in from the north fence and about } \\
5 \text { meters in from the east fence. }\end{array}$ \\
\hline & $\mathrm{S} 12$ & $\begin{array}{l}\text { In the north east quadrant of the Large Asphalt Pad, } \\
\text { about } 1 \text { meter in from the north fence and about } \\
5 \text { meters in from the east fence. }\end{array}$ \\
\hline
\end{tabular}


Table 3-2. 303-K Storage Facility: Sampling and Analysis Summary for Interior Samples.

\begin{tabular}{|c|c|c|c|c|c|c|}
\hline \multirow{2}{*}{$\begin{array}{l}\text { Sample } \\
\text { location }\end{array}$} & \multirow{2}{*}{ Matrix } & \multicolumn{2}{|c|}{$\begin{array}{l}\text { Metals constituents of } \\
\text { concerns }\end{array}$} & \multirow{2}{*}{$\begin{array}{c}\begin{array}{c}\text { Anion } \\
\text { constituent } \\
\text { of concern }\end{array} \\
\begin{array}{c}\text { EPA } \\
\text { Methods }\end{array}\end{array}$} & \multicolumn{2}{|c|}{$\begin{array}{l}\text { Semivolatile organic } \\
\text { constituent of concern }\end{array}$} \\
\hline & & $\begin{array}{l}\text { SW-846 } \\
\text { methods }^{\text {a }}\end{array}$ & LKPA $^{b}$ & & $\begin{array}{c}\text { Field } \\
\text { screening }\end{array}$ & $\begin{array}{l}\text { SW-846 } \\
\text { analysis }^{\mathrm{d}}\end{array}$ \\
\hline $\mathrm{Cl}$ & Concrete & Yes & Yes & Yes & $\mathrm{No}^{\mathrm{e}}$ & Yes \\
\hline $\begin{array}{l}\text { C2 } \\
\text { C2 (duplicate) }\end{array}$ & $\begin{array}{l}\text { Concrete } \\
\text { Concrete }\end{array}$ & $\begin{array}{l}\text { Yes } \\
\text { Yes }\end{array}$ & $\begin{array}{l}\text { Yes } \\
\text { Yes }\end{array}$ & $\begin{array}{l}\text { Yes } \\
\text { Yes }\end{array}$ & No & $\begin{array}{l}\text { No } \\
\text { No }\end{array}$ \\
\hline $\mathrm{C} 3$ & Concrete & Yes & Yes & Yes & No & No \\
\hline $\begin{array}{l}\text { Concrete } \\
\text { sampling } \\
\text { equipment } \\
\text { blank }^{f}\end{array}$ & $\begin{array}{l}\text { Deionized } \\
\text { water }\end{array}$ & Yes & No & Yes & No & No \\
\hline
\end{tabular}

- SW-846 Methods: 6010, 7421, 7060, and 7471.

- LKPA = Laser Kinetic Phosphorimetric Analysis.

c - Inorganic anions analysis includes U.S. Environmental Protection Method 300.0.

d - Semivolatile organic analysis (for pentachlorophenol) by SW-846 Method 4010.

- Field screening not performed.

f - One equipment blank per day of concrete sampling. 
Table 3-3. 303-K Storage Facility: Sampling and Analysis Summary for the Exterior Samples.

\begin{tabular}{|c|c|c|c|c|c|c|}
\hline \multirow{2}{*}{$\begin{array}{l}\text { Sample } \\
\text { Location }\end{array}$} & \multirow{2}{*}{ Matrix } & \multirow{2}{*}{$\begin{array}{l}\text { Sample } \\
\text { Interval }\end{array}$} & \multicolumn{2}{|c|}{$\begin{array}{l}\text { Metal Constituents of } \\
\text { Concern }\end{array}$} & \multicolumn{2}{|c|}{$\begin{array}{l}\text { Semivolatile Organic } \\
\text { Constituents of Concern }\end{array}$} \\
\hline & & & $\begin{array}{l}\text { SW-846 } \\
\text { Analysis }^{\mathrm{a}}\end{array}$ & $\mathrm{LKPA}^{b}$ & $\begin{array}{c}\text { Field } \\
\text { Screening }\end{array}$ & $\begin{array}{l}\text { SW-846 } \\
\text { Analysis }^{c}\end{array}$ \\
\hline S1 & Soil & Upper only & Yes & Yes & Yes & Yes \\
\hline$\$ 2$ & Soil & Upper only & Yes & Yes & Yes & Yes \\
\hline S3 & Soil & Upper only & Yes & Yes & Yes & Yes \\
\hline$\$ 4$ & Soil & Upper only & Yes & Yes & Yes & Yes \\
\hline S5 & Soil & Upper only & Yes & Yes & $\mathrm{No}^{d}$ & Yes \\
\hline S6 & Soil & Upper only & Yes & Yes & Yes & Yes \\
\hline S6 (duplicate) & Soil & Upper only & Yes & Yes & Yes & Yes \\
\hline S7 & Soil & Upper only & Yes & Yes & Yes & Yes \\
\hline S8 & Soil & Upper only & Yes & Yes & $\mathrm{No}^{\mathrm{d}}$ & Yes \\
\hline S8 (duplicate) & Soil & Upper only & Yes & Yes & $\mathrm{No}^{\mathrm{d}}$ & Yes \\
\hline \$9 & Soil & Upper only & Yes & Yes & Yes & Yes \\
\hline $\mathrm{S} 10$ & Soil & Upper only & Yes & Yes & $\mathrm{No}^{d}$ & Yes \\
\hline S10 (duplicate) & Soil & Upper only & Yes & Yes & No ${ }^{d}$ & Yes \\
\hline \$11 & Soil & $\begin{array}{l}\text { Upper \& } \\
\text { Lower }\end{array}$ & Yes & Yes & $\mathrm{No}^{\mathrm{d}}$ & Yes \\
\hline Sll (duplicate) & Soil & Lower only & Yes & Yes & $\mathrm{No}^{\mathrm{d}}$ & Yes \\
\hline $\mathrm{S} 12$ & Soil & $\begin{array}{l}\text { Upper \& } \\
\text { lower }\end{array}$ & Yes & Yes & $\mathrm{No}^{\mathrm{d}}$ & Yes \\
\hline $\begin{array}{l}\text { Soil Sampling } \\
\text { Equipment } \\
\text { Blank }^{\circ}\end{array}$ & $\begin{array}{l}\text { Deionized } \\
\text { Water }\end{array}$ & $\mathrm{n} / \mathrm{a}$ & Yes & No & No & No \\
\hline
\end{tabular}

- SW-846 Methods: $6010,7421,7060$, and 7471 .

b - LKPA = Laser Kinetic Phosphorimetric Analysis.

c - Semivolatile organic analysis (for pentachlorophenol) by SW-846 Method 4010.

d - Field screening not performed as planned.

e - One equipment blank per day of soil sampling. Soil sampling occurred over 2 days; therefore, two samples were collected. 
HNF-2959

Table 3-4. Summary and Cross-Reference of Sample Numbers to Sample Information.

\begin{tabular}{|c|c|c|c|}
\hline Sample Number & Date and Time & Sample Type or Location & Sample Media \\
\hline BOMB44 & $10 / 30 / 97 ; 1450$ & $\mathrm{Cl}$ & Concrete \\
\hline BOMB45 & $10 / 30 / 97 ; 1450$ & $\mathrm{C} 3$ & $"$ \\
\hline BOMB46 & $10 / 30 / 97 ; 1440$ & $\mathrm{C} 2$ & $"$ \\
\hline BOMB47 & $10 / 30 / 97 ; 1440$ & C2 Duplicate & $"$ \\
\hline BOMB48 & $10 / 30 / 97 ; 1305$ & Concrete Equipment Blank & Deionized Water \\
\hline BOMB49 & $10 / 30 / 97 ; 1120$ & Soil Equipment Blank & $"$ \\
\hline BOM8Y6 & $10 / 29 / 97 ; 1025$ & Soil Equipment Blank & $"$ \\
\hline BOM8Y7 & $10 / 29 / 97 ; 1210$ & S9 & Soil \\
\hline BOM8Y8 & $10 / 29 / 97 ; 1125$ & S6 & $"$ \\
\hline BOM8Y9 & $10 / 29 / 97 ; 1125$ & S6 Duplicate & $"$ \\
\hline BOM 900 & $10 / 29 / 97 ; 1155$ & S7 & $"$ \\
\hline BOM901 & $10 / 29 / 97 ; 1216$ & S3 & $"$ \\
\hline BOM902 & $10 / 29 / 97 ; 1236$ & $\mathrm{~S} 4$ & $"$ \\
\hline BOM903 & $10 / 29 / 97 ; 1305$ & S1 & $"$ \\
\hline BOM904 & $10 / 29 / 97 ; 1234$ & S10 & $"$ \\
\hline BOM905 & $10 / 30 / 97 ; 1320$ & S12 Lower & $"$ \\
\hline BOM906 & $10 / 29 / 97 ; 1140$ & S2 & $"$ \\
\hline BOM907 & $10 / 30 / 97 ; 1107$ & S8 & $"$ \\
\hline BOM908 & $10 / 30 / 97 ; 1022$ & S10 Duplicate & $"$ \\
\hline BOM909 & $10 / 30 / 97 ; 1310$ & S11 Lower & $"$ \\
\hline BOM910 & $10 / 30 / 97 ; 1310$ & S12 Upper & $"$ \\
\hline B0M911 & $10 / 30 / 97 ; 1025$ & S5 & $"$ \\
\hline BOM912 & $10 / 30 / 97 ; 1107$ & S8 Duplicate & $"$ \\
\hline BOM913 & $10 / 30 / 97 ; 1340$ & S11 Lower Duplicate & $"$ \\
\hline BOM914 & $10 / 30 / 97 ; 1120$ & S11 Upper & $"$ \\
\hline
\end{tabular}


HNF-2959

Table 3-5. Summary and Cross-reference of Sample Locations to Sample Numbers.

\begin{tabular}{|c|c|c|c|}
\hline Sample Type or Location & Date and Time & Sample Number & Sample Media \\
\hline $\mathrm{Cl}$ & $10 / 30 / 97 ; 1450$ & BOMB44 & Concrete \\
\hline $\mathrm{C} 2$ & $10 / 30 / 97 ; 1440$ & BOMB46 & i" \\
\hline C2 Duplicate & $10 / 30 / 97 ; 1440$ & BOMB47 & $"$ \\
\hline $\mathrm{C} 3$ & $10 / 30 / 97 ; 1450$ & BOMB45 & $"$ \\
\hline Concrete Equipment Blank & $10 / 30 / 97 ; 1305$ & BOMB48 & Deionized Water \\
\hline S1 & $10 / 29 / 97 ; 1305$ & BOM903 & Soil \\
\hline $\mathbf{S} 2$ & $10 / 29 / 97 ; 1140$ & BOM906 & $"$ \\
\hline S3 & $10 / 29 / 97 ; 1216$ & BOM901 & $"$ \\
\hline$S 4$ & $10 / 29 / 97 ; 1236$ & BOM904 & $"$ \\
\hline S5 & $10 / 30 / 97 ; 1025$ & BOM911 & $"$ \\
\hline \$6 & $10 / 29 / 97 ; 1125$ & BOM8Y8 & $"$ \\
\hline S6 Duplicate & $10 / 29 / 97 ; 1125$ & BOM8Y9 & $"$ \\
\hline S7 & $10 / 29 / 97 ; 1155$ & BOM900 & $"$ \\
\hline S8 & $10 / 30 / 97 ; 1107$ & BOM907 & $"$ \\
\hline S8 Duplicate & $10 / 30 / 97 ; 1107$ & BOM12 & $"$ \\
\hline \$9 & $10 / 29 / 97 ; 1210$ & BOM8Y7 & $"$ \\
\hline $\mathrm{S} 10$ & $10 / 29 / 97 ; 1324$ & BOM904 & $"$ \\
\hline S10 Duplicate & $10 / 30 / 97 ; 1022$ & BOM908 & $"$ \\
\hline S11 Upper & $10 / 30 / 97 ; 1120$ & BOM914 & $"$ \\
\hline S11 Lower & $10 / 30 / 97 ; 1310$ & BOM909 & $"$ \\
\hline S11 Lower Duplicate & $10 / 30 / 97 ; 1340$ & BOM913 & $"$ \\
\hline S12 Upper & $10 / 30 / 97 ; 1310$ & BOM910 & $"$ \\
\hline S12 Lower & $10 / 30 / 97 ; 1320$ & BOM905 & $"$ \\
\hline Soil Equipment Blank & $10 / 29 / 97 ; 1025$ & BOM8Y6 & Deionized water \\
\hline Soil Equipment Blank & $10 / 30 / 97 ; 1120$ & BOMB49 & $"$ \\
\hline
\end{tabular}


HNF-2959

Table 3-6. Sampling Container Information.

\begin{tabular}{|l|l|l|l|l|}
\hline \multicolumn{1}{|c|}{ Sample Media } & $\begin{array}{c}\text { Container } \\
\text { Size }\end{array}$ & \multicolumn{1}{|c|}{ Container Type } & Lot Number & \multicolumn{1}{|c|}{ Analysis } \\
\hline Concrete \& Soil & $125 \mathrm{ml}$ & Poly wide-mouth & L41230040 & Anions \\
\hline Concrete \& Soil & $125 \mathrm{ml}$ & $\begin{array}{l}\text { Amber glass wide- } \\
\text { mouth }\end{array}$ & $\begin{array}{l}65096030 \\
\text { organics }\end{array}$ \\
\hline Concrete \& Soil & $125 \mathrm{ml}$ & Poly wide-mouth & L7009020 & Metals \\
\hline $\begin{array}{l}\text { Equipment Blanks } \\
\text { (Water) }\end{array}$ & $500 \mathrm{ml}$ & Poly wide-mouth & L7119020 & Metals \\
\hline
\end{tabular}

$\mathrm{ml}=$ milliliters . 
HNF-2959

4.0 FIELD SCREENING FOR PENTACHLOROPHENOL

As allowed in the modified SAP, immunoassay field screening for pentachlorophenol was used during the sampling. Field screening was conducted on October 29 and 30, 1997. The sampler's log book entries (Appendix A) include the field screening activities. The field screening test results are summarized on Table 4-1. Because of inconsistent results, field screening was not used to establish the presence or absence of pentachlorophenol.

\subsection{FIELD SCREENING KIT METHODOLOGY}

Field screening was done using two Penta Riscß Soil Test System kits, manufactured by Ensys Inc. The kits were purchased from Strategic Diagnostics, Inc. Both Penta Risc $B$ kits were part of Lot Number $7 \mathrm{H} 2227$ and both had an expiration date of February 1998. A copy of the kit instructions are provided in Appendix D. As used, the test kit had minimum detection limits of 1 part per million, 10 parts per million, and 100 parts per million.

The modified SAP had the following requirements for field screening.

- One concrete sample (at location $\mathrm{C} 1$ ) would be field screened.

- All soil samples would be field screened.

- If field screening gave a positive response, a sample would be collected for laboratory analysis.

\subsection{FIELD SCREENING RESULTS}

The field screening results are presented in Table 4-1. The field screening by immunoassay was halted after eight samples as results provided inconsistent data. Test results were inconsistent for single samples and for one sample and its duplicate sample. Examples of the inconsistent results included the following:

- At sample location S3: Negative results at 1 or 100 parts per million, but a positive result at 10 parts per million

- At sample location S7: Negative results at 1 or 10 parts per million, but positive results at 100 parts per million

- At sample location $\mathbf{6} 6$ duplicate: Positive results at 1 and 100 parts per million but negative results at 10 parts per million

- Results between S6 and S6 duplicate were not consistent: S6 had a positive result at 1 part per million and negative results at 10 or 100 parts per million while S6 duplicate had positive results at 1 and 100 parts per million but negative results at 10 parts per million.

As a result of the inconsistencies, it was determined that the test was not providing useful information and that the samples for semivolatile organic analysis would have to be sent to an offsite laboratory. With inconsistent field screening results, a field change (Appendix C) was implemented to discontinued field screening and collect samples for laboratory analysis. 
1 The results of the laboratory analysis are discussed in Sections 5.0,6.0,7.0, and 8.0. The laboratory

2 analysis of the samples for pentachlorophenol confirmed that the field screening results were giving false

3 positive readings.

\section{$4 \quad 4.3$ DEVIATIONS DURING FIELD SCREENING}

5 With the field screening being discontinued per the field change, several additional requirements of the

6 modified SAP were not met. Not meeting these requirements does not affect the conclusions of this report

- 7 as more rigorous and accurate laboratory analysis for pentachlorophenol are being used. Requirements not

8 met as the result of discontinuing the field screening included the following:

- Not conducting field screening on concrete from sample location $\mathrm{Cl}$

- Not conducting field screening on soil from sample locations S5, S8, S10, S10 duplicate, S11 Upper, S11 Lower, S12 Upper, and S12 Lower

15 - Not verifying the method detection limit for the field screening kit. 
HNF-2959

2

Table 4-1. Results from the Field Screening for Pentachlorophenol.

\begin{tabular}{||c|c|c|c|c|}
\hline \multirow{2}{*}{$\begin{array}{c}\text { Sample } \\
\text { Location }\end{array}$} & Date & \multicolumn{2}{|c|}{ Results of field screening at each minimum detection level } \\
\cline { 2 - 5 } & & $1 \mathrm{ppm}$ & $10 \mathrm{ppm}$ & $100 \mathrm{ppm}$ \\
\hline S1 & $10 / 30 / 97$ & POSITIVE & POSITIVE & Negative \\
S2 & $10 / 29 / 97$ & POSITIVE & POSITIVE & Negative \\
S3 & $10 / 30 / 97$ & Negative & POSITIVE & Negative \\
S4 & $10 / 30 / 97$ & POSITIVE & Negative & Negative \\
S6 & $10 / 29 / 97$ & POSITIVE & Negative & Negative \\
S6 Duplicate- & $10 / 29 / 97$ & POSITIVE & Negative & POSITIVE \\
S7 & $10 / 29 / 97$ & Negative & Negative & POSITIVE \\
S9 & $10 / 29 / 97$ & Negative & Negative & Negative \\
\hline
\end{tabular}

ppm $=$ parts per million 
HNF-2959

This page intentionally left blank. 


\subsection{ANALYSES}

2 Samples were analyzed for metals, inorganic anions, and semivolatile organic constituents. The analytical

3 methods are summarized on Table 5-1. The analysis of all samples occurred at LAS, Inc. in Las

4 Vegas, Nevada. Both the raw and validated data packages were transmitted to Ecology separately

5 (98-EAP-145 and 98-EAP-346).

6

Both soil and concrete samples included the analysis for metal constituents of concern. The concrete samples also were analyzed for the inorganic anion constituents of concern. The soil samples included the analysis for the semivolatile organic constituents of concern. Only one of the concrete samples (from sample location $\mathrm{Cl}$ ) included the analysis for the semivolatile organic constituents of concern. Although the various analytical methods identified additional constituents, these are not presented or discussed as these are not identified as constituents of concern in the closure plan and in the modified SAP.

\subsection{METAL ANALYSIS}

The analytical methods required by the modified SAP for the metals analysis are identified on Table 5-1. The data from the sample analysis for the metals constituents of concern is summarized on Tables 5-2 and Table 5-3. The data validation is discussed in Section 6.0 and the data are evaluated in Section 8.0.

The modified SAP required the use of SW-846 Method 7741 "Silver (Atomic Absorption, Furnace Technique)" to determine the concentrations of silver. The two offsite laboratories currently under contract have both discontinued use of Method 7741 because the method had poor results. SW-846, Method 6010A "Inductively Coupled Plasma-Atomic Emission Spectroscopy" was used in its place as this method meets the quality control limits required by the modified SAP. This change had been documented in the 303-K Storage Facility Project Manager Meeting of November 6, 1997 (DOE-RL and Ecology, 1997).

\subsection{ANION ANALYSES}

The analytical method used for the anion analysis is identified on Table 5-1. The data from the sample analysis for the inorganic anion constituents of concern is summarized on Tables 5-2 and Table 5-3. The data validation is discussed in Section 6.0 and the data are evaluated in Section 8.0.

\subsection{SEMIVOLATILE ORGANIC ANALYSES}

The analytical method used for the semivolatile organic analysis is identified on Table 5-1. The data from the sample analysis for the semivolatile organic constituent of concern are summarized on Tables 5-2 and Table 5-3. The data validation is discussed in Section 6.0 and the data are evaluated in Section 8.0. 
HNF-2959

Table 5-1. Constituents of Concern, Sample Media, and Analytical Methods.

\begin{tabular}{|c|c|c|}
\hline Constituent of Concern & Sample Media & Analytical Method \\
\hline Arsenic & Soil and Concrete & SW-846 Method 7060 \\
\hline Barium & Soil and Concrete & SW-846 Method 6010A \\
\hline Beryllium & Soil and Concrete & SW-846 Method 6010A \\
\hline Cadmium & Soil and Concrete & SW-846 Method 6010A \\
\hline Chromium & Soil and Concrete & SW-846 Method 6010A \\
\hline Lead & Soil and Concrete & SW-846 Method 7421 \\
\hline Mercury & Soil and Concrete & SW-846 Method 7421 \\
\hline Nickel & Soil and Concrete & SW-846 Method 6010A \\
\hline Silver & Soil and Concrete & SW-846 Method 6010A \\
\hline Uranium & Soil and Concrete & Laser Kinetic Phosphorescence \\
\hline Chloride ion & Concrete & EPA Method 300.0 \\
\hline Nitrate ion & Concrete & EPA Method 300.0 \\
\hline Nitrite ion & Soil and Concrete* & EPA Method 300.0 \\
\hline Pentachlorophenol & SW-846 Method 8270 \\
\hline
\end{tabular}

* - Per the modified SAP, only one concrete sample (at sample location C1) was analyzed for pentachlorophenol. 
Table 5-2. Interior Sampling Data Summary.

(sheet 1 of 2)

\begin{tabular}{|c|c|c|c|c|c|c|}
\hline $\begin{array}{l}\text { SAMPLE } \\
\text { LOCATION }\end{array}$ & $\begin{array}{l}\text { Clean-up } \\
\text { Levels }\end{array}$ & $\mathrm{Cl}$ & $\mathrm{C} 2$ & C2 Duplicate & $\mathrm{C} 3$ & $\begin{array}{l}\text { Equipment } \\
\text { Blank }\end{array}$ \\
\hline $\begin{array}{l}\text { SAMPLE } \\
\text { NUMBER }\end{array}$ & $\mathbf{n} / \mathbf{a}$ & BOMB44 & BOMB46 & BOMB47 & BOMB45 & BOMB48 \\
\hline UNTTS & $\mathrm{mg} / \mathrm{kg}$ & $\mathrm{mg} / \mathrm{kg}$ & $\mathrm{mg} / \mathrm{kg}$ & $\mathrm{mg} / \mathrm{kg}$ & $\mathrm{mg} / \mathrm{kg}$ & $\mathrm{mg} / \mathrm{L}$ \\
\hline Arsenic & 9.18 & 2.85 & 2.88 & 2.98 & 6.57 & $<0.003 \mathrm{U}$ \\
\hline Barium & 5600 & 252 & 245 & 275 & 97.40 & $0.0025 \mathrm{~B}$ \\
\hline Beryllium & 1.81 & $0.33 \mathrm{~B}$ & $0.24 \mathrm{~B}$ & $0.27 \mathrm{~B}$ & $0.24 \mathrm{~B}$ & $<0.001 \mathrm{U}$ \\
\hline Cadmium & 80 & 1.94 & 1.90 & 3.51 & $0.31 \mathrm{~B}$ & $<0.002 \mathrm{U}$ \\
\hline Chromium & 400 & 22.1 & 23.10 & 28.90 & 16.20 & $<0.003 \mathrm{U}$ \\
\hline Lead & 250 & $311 \mathrm{~J}$ & $157 \mathrm{~J}$ & $289 \mathrm{~J}$ & $4.91 \mathrm{~J}$ & $0.0022 \mathrm{U}$ \\
\hline Mercury & 24 & $0.49 \mathrm{~J}$ & $<0.09$ UR & $<0.09$ UR & $<0.10 \mathrm{UR}$ & $<0.00020 \mathrm{UJ}$ \\
\hline Nickel & 1600 & 16.00 & 20.20 & 26.50 & 8.12 & $<0.009 \mathrm{U}$ \\
\hline Silver & 400 & 2.99 & $0.61 \mathrm{~B}$ & 1.05 & $<0.38 \mathrm{U}$ & $<0.004 \mathrm{U}$ \\
\hline Uranium & $n / a$ & $4133 \pm 327$ & $567 \pm 34$ & $1317 \pm 86$ & $5.40 \pm 0.68$ & NR \\
\hline Chloride ion & 541.2 & 114. & 132 & 116 & 36 & NR \\
\hline Nitrate ion & 128000 & 2.08 & 6.11 & 5.72 & 4.56 & NR \\
\hline Nitrite ion & 8000 & 10.30 & 1.20 & 1.05 & 0.40 & NR \\
\hline Pentachlorophenol & 8.33 & $3.3 \mathrm{U}$ & NR & NR & $\mathrm{NR}$ & $\mathrm{NR}$ \\
\hline UNITS & $\mathrm{pCi} / \mathrm{gm}$ & $\mathrm{pCi} / \mathrm{gm}$ & $\mathrm{pCi} / \mathrm{gm}$ & $\mathrm{pCi} / \mathrm{gm}$ & $\mathrm{pCi} / \mathrm{gm}$ & $\mathrm{pCi} / \mathrm{gm}$ \\
\hline Uranium-234 & $\mathrm{n} / \mathrm{a}$ & $1960 \pm 140$ & $232 \pm 12$ & $570 \pm 35$ & $2.11 \pm .24$ & NR \\
\hline Uranium-235 & $\mathbf{n} / \mathbf{a}$ & $33 \pm 31$ & $3.4 \pm 2.1$ & $4.0 \pm 6.9$ & $0.161 \pm 0.063 \mathrm{~J}$ & NR \\
\hline Uranium-238 & $\mathrm{n} / \mathrm{a}$ & $1390 \pm 110$ & $190 \pm 11$ & $442 \pm 28$ & $1.79 \pm 0.22$ & NR \\
\hline
\end{tabular}


$4 \mathrm{n} / \mathrm{a}=$ not applicable

$5 \mathrm{mg} / \mathrm{kg} \quad=$ milligrams per kilogram (equivalent to parts per million [ppm])

$6 \mathrm{mg} / \mathrm{L}=$ milligrams per liter (equivalent to $\mathrm{ppm}$ )

$7 \mathrm{pCi} / \mathrm{gm}=$ picocuries per gram

8 NR $=$ Not required by the modified sampling and analysis pian.

Total uranium concentrations were calculated from the isotope concentrations using the following conversion factors:

\section{Data Qualifiers:}

$17 \mathrm{U}$ Indicates that the compound or analyte was analyzed for and not detected in the sample. The value 18 reported is the sample quantitation limit corrected for sample dilution and moisture content by the laboratory.

UJ Indicates that the compound or analyte was analyzed for and not detected in the sample. Due to a QC deficiency identified during the data validation, the associated quantitation limit is an estimate.

UR Indicates that the compound or analyte was analyzed for and not detected in the sample. Additionally, the data is unusable due to an identified QC deficiency. Ecology is allowing these data to be used (Section 6.3).

J Indicates that the compound or analyte was analyzed for and detected. Because of a quality control deficiency identified during the data validation, the associated concentration is an estimate, but the data are usable for decision-making purposes.

B For inorganic data, indicates that the analyte concentration is less than the contract required detection limit, but greater than the instrument detection limits. 
Table 5-3. Exterior Sampling Data Summary

(sheet 1 of 4)

\begin{tabular}{|c|c|c|c|c|c|c|c|c|}
\hline $\begin{array}{l}\text { SAMPLE } \\
\text { LOCATION }\end{array}$ & $\begin{array}{c}\text { CLEAN- } \\
\text { UP } \\
\text { LEVELS }\end{array}$ & S1 & s2 & s3 & $\$ 4$ & S5 & S6 & S6 Duplicate \\
\hline $\begin{array}{l}\text { SAMPLE } \\
\text { NUMBER }\end{array}$ & $n / a$ & BOM903 & BOM906 & BOM901 & BOM902 & ВОМ911 & BOM8Y8 & BOM8Y9 \\
\hline UNITS & $\mathrm{mg} / \mathrm{kg}$ & $\mathrm{mg} / \mathrm{kg}$ & $\mathrm{mg} / \mathrm{kg}$ & $\mathrm{mg} / \mathrm{kg}$ & $\mathrm{mg} / \mathrm{kg}$ & $\mathrm{mg} / \mathrm{kg}$ & $\mathrm{mg} / \mathrm{kg}$ & $\mathrm{mg} / \mathrm{kg}$ \\
\hline Arsenic & 9.18 & 3.02 & 2.64 & 1.87 & 3.41 & 2.90 & 1.94 & 2.16 \\
\hline Barium & 5600 & 74.40 & 115.00 & 84.40 & 122.00 & 120.00 & 63.40 & 58.40 \\
\hline Berylitum & 1.81 & $0.22 \mathrm{~B}$ & $0.24 \mathrm{~B}$ & $0.26 \mathrm{~B}$ & $0.25 \mathrm{~B}$ & $0.28 \mathrm{~B}$ & $0.14 \mathrm{~B}$ & $0.15 \mathrm{~B}$ \\
\hline Cadmium & 80 & $<0.21 \mathrm{U}$ & $0.24 \mathrm{~B}$ & $0.35 \mathrm{~B}$ & $0.44 \mathrm{~B}$ & 0.68 & $0.36 \mathrm{~B}$ & $0.3 \mathrm{~B}$ \\
\hline Chromium & 400 & 10.20 & 12.40 & 9.37 & 42.10 & 15.90 & 25.20 & 25.6 \\
\hline Lead & 250 & 5.06 & 13.80 & 13.40 & 20.10 & 17.10 & 7.70 & 10.60 \\
\hline Mercury & 24 & $<0.09 \mathrm{UJJ}$ & $<0.10 \mathrm{UJ}$ & $<0.11$ UJ & $<0.10 \mathrm{UJ}$ & $<0.11 \mathrm{UJ}$ & $<0.11 \mathrm{UJ}$ & $<0.10$ UJ \\
\hline Nickel & 1600 & 11.70 & 16.00 & 23.50 & 30.00 & 150.00 & 25.60 & 50.6 \\
\hline Silver & 400 & $0.43 \mathrm{~B}$ & $<0.41 \mathrm{U}$ & $<0.45 \mathrm{U}$ & 2.05 & $0.88 \mathrm{~B}$ & $0.43 \mathrm{~B}$ & 1.28 \\
\hline Uranium & $n / 3$ & $2.30 \pm 0.17$ & $22.6 \pm 1.8$ & $19.4 \pm 1.6$ & $741 \pm 50$ & $105 \pm 2$ & $71.1 \pm 4.7$ & $74.6 \pm 5.0$ \\
\hline Pentachlorophenol & 8.33 & $<3.5 \mathrm{U}$ & $<3.4 \mathrm{U}$ & $<3.8 \mathrm{U}$ & $<3.4 \mathrm{UJ}$ & $<3.6 \mathrm{U}$ & $<3.5 \mathrm{U}$ & $<3.5 \mathrm{U}$ \\
\hline UNITS & $\mathrm{pCi} / \mathrm{gm}$ & $\mathrm{pCi} / \mathrm{gm}$ & $\mathrm{pCi} / \mathrm{gm}$ & $\mathrm{pCi} / \mathrm{gm}^{2}$ & $\mathrm{pCi} / \mathrm{gm}$ & $\mathrm{pCi} / \mathrm{gm}$ & $\mathrm{pCi} / \mathrm{gm}$ & $\mathrm{pCi} / \mathrm{gm}$ \\
\hline Uranium-234 & $n / a$ & $0.88 \pm 0.16 \mathrm{~J}$ & $7.57 \pm 0.59$ & $8.84 \pm 0.66$ & $257 \pm 17$ & $41.1 \pm 2.5$ & $24.6 \pm 1.6$ & $24.5 \pm 1.6$ \\
\hline Uranium-235 & nia & $0.096 \pm 0.056 \mathrm{~J}$ & $0.59 \pm 0.13$ & $0.69 \pm 0.14$ & $13.6 \pm 2.7$ & $3.14 \pm 0.41$ & $1.71 \pm 0.28$ & $2.17 \pm 0.3$ \\
\hline Uranium-238 & $n / \mathbf{a}$ & $0.75 \pm 0.15$ & $7.47 \pm 0.59$ & $6.37 \pm 0.52$ & $246 \pm 16$ & $34.7 \pm 0.61$ & $23.4 \pm 1.5$ & $24.6 \pm 1.6$ \\
\hline
\end{tabular}


HNF-2959

Table 5-3: Exterior Sampling Data Summary

(sheet 2 of 4)

\begin{tabular}{|c|c|c|c|c|c|c|c|}
\hline $\begin{array}{l}\text { SAMPLE } \\
\text { LOCATION }\end{array}$ & $\begin{array}{c}\text { CLEAN. } \\
\text { UP } \\
\text { LEVELS }\end{array}$ & S7 & $\$ 8$ & S8 Duplicate & s9 & $\mathbf{S 1 0}$ & $\begin{array}{c}\text { S10 } \\
\text { Duplicate }\end{array}$ \\
\hline $\begin{array}{l}\text { SAMPLE } \\
\text { NUMBER }\end{array}$ & $n / a$ & BOM900 & BOM907 & BOM 912 & BOM8Y7 & - BOM904 & BOM908 \\
\hline UNITS & $\mathrm{mg} / \mathrm{kg}$ & $\mathrm{Mg} / \mathrm{kg}$ & $\mathrm{mg} / \mathrm{kg}$ & $\mathrm{mg} / \mathrm{kg}$ & $\mathrm{mg} / \mathrm{kg}$ & $\mathrm{mg} / \mathrm{kg}$ & $\mathrm{mg} / \mathrm{kg}$ \\
\hline Arsenic & 9.18 & 2.63 & 2.36 & 2.03 & 1.92 & 1.99 & 2.83 \\
\hline Barium & 5600 & 133.00 & 65.40 & 68.8 & 65.50 & 67.30 & 84.60 \\
\hline Beryllium & 1.81 & $0.24 \mathrm{~B}$ & $0.18 \mathrm{~B}$ & $0.18 \mathrm{~B}$ & $0.18 \mathrm{~B}$ & $0.18 \mathrm{~B}$ & $0.24 \mathrm{~B}$ \\
\hline Cadmium & 80 & $0.44 \mathrm{~B}$ & $<0.21 \mathrm{U}$ & $0.28 \mathrm{~B}$ & $<0.21 \mathrm{U}$ & $<0.21 \mathrm{U}$ & $<0.22 \mathrm{U}$ \\
\hline Chromium & 400 & 14.70 & 9.74 & 9.35 & 10.40 & 10.10 & 11.00 \\
\hline Lead & 250 & 22.50 & 5.58 & 5.84 & 6.88 & 7.94 & $4.8 I$ \\
\hline Mercury & 24 & $<0.096 \mathrm{UJ}$ & $<0.11 \mathrm{UJ}$ & $<0.10 \mathrm{UJ}$ & $<0.11 \mathrm{UJ}$ & $<0.09 \mathrm{UJ}$ & $<0.11 \mathrm{UJ}$ \\
\hline Nickel & 1600 & 13.40 & 9.02 & 9.91 & 10.10 & 10.20 & 11.5 \\
\hline Silver & 400 & $0.86 \mathrm{~B}$ & $0.58 \mathrm{~B}$ & $0.48 \mathrm{~B}$ & $0.47 \mathrm{~B}$ & $0.53 \mathrm{~B}$ & $<0.43 \mathrm{U}$ \\
\hline Uranium & $\mathrm{N} / \mathbf{a}$ & $552 \div 38$ & $14.2 \pm 1.5$ & $23.3 \pm 1.9$ & $69.8 \pm 5.3$ & $25.2 \pm 2.0$ & $17.4 \pm 1.7$ \\
\hline Pentachlorophenol & 8.3 & $<3.50 \mathrm{U}$ & $<3.5 \mathrm{U}$ & $<3.5 \mathrm{U}$ & $<3.5 \mathrm{U}$ & $<3.5 \mathrm{U}$ & $<3.5 \mathrm{U}$ \\
\hline UNITS & $\mathrm{pCi} / \mathrm{gm}$ & $\mathrm{pCi} / \mathrm{gm}$ & $\mathrm{pCi} / \mathrm{gm}$ & $\mathrm{pCi} / \mathrm{gm}$ & $\mathrm{pCi} / \mathrm{gm}$ & $\mathrm{pCi} / \mathrm{gm}$ & $\mathrm{pCi} / \mathrm{gm}$ \\
\hline Uranium-234 & $\mathbf{n} / \mathbf{a}$ & $181 \pm 12$ & $4.84 \pm 0.48$ & $8.33 \pm 0.64$ & $24.3 \pm 1.8$ & $8.21 \pm 0.65$ & $6.14 \pm 0.56$ \\
\hline Uranium-235 & $\mathrm{n} / \mathrm{a}$ & $11.4 \pm 2.1$ & $0.47 \pm 0.13$ & $0.336 \pm 0.10 \mathrm{~J}$ & $1.23 \pm 0.3$ & $0.63 \pm 0.14$ & $0.38 \pm 0.12$ \\
\hline Uranium-238 & $n / a$ & $183 \pm 12$ & $4.66 \pm 0.47$ & $7.78 \pm 0.61$ & $23.2 \pm 1.7$ & $8.35 \pm 0.65$ & $5.75 \pm 0.54$ \\
\hline
\end{tabular}


HNF-2959

Table 5-3: Exterior Sampling Data Summary

(sheet 3 of 4 )

\begin{tabular}{|c|c|c|c|c|c|c|c|c|}
\hline $\begin{array}{l}\text { SAMPLE } \\
\text { LOCATION }\end{array}$ & $\begin{array}{c}\text { CLEAN- } \\
\text { UP } \\
\text { LEVEL }\end{array}$ & S11 Upper & s11 Lower & $\begin{array}{l}\text { S11 Lower } \\
\text { Duplicate }\end{array}$ & S12 Upper & $\begin{array}{c}\$ 12 \\
\text { Lower }\end{array}$ & $\begin{array}{l}\text { Equipment } \\
\text { Blank }\end{array}$ & $\begin{array}{c}\text { Equipment } \\
\text { Blank }\end{array}$ \\
\hline $\begin{array}{l}\text { SAMPLE. } \\
\text { NUMBER }\end{array}$ & $\mathbf{n} / \mathbf{a}$ & BOM914 & BOM909 & BOM913 & BOM910 & BOM905 & B0M8Y6 & BOM49 \\
\hline UNTS & $\mathrm{mg} / \mathrm{kg}$ & $\mathrm{mg} / \mathrm{kg}$ & $\mathrm{mg} / \mathrm{kg}$ & $\mathrm{mg} / \mathrm{kg}$ & $\mathrm{mg} / \mathrm{kg}$ & $\mathrm{mg} / \mathrm{kg}$ & $\mathrm{mg} / \mathrm{L}$ & $\mathrm{mg} / \mathrm{L}$ \\
\hline Arsenic & 9.18 & 2.39 & 2.61 & 2.29 & 1.99 & 2.43 & $<0.003 \mathrm{U}$ & $<0.003 U$ \\
\hline Barium & 5600 & 93.90 & 88.40 & 83.20 & 266.00 & 111.00 & $<0.001 \mathrm{U}$ & $<0.001 \mathrm{U}$ \\
\hline Beryllium & 1.81 & $0.23 \mathrm{~B}$ & $0.24 \mathrm{~B}$ & $0.22 \mathrm{~B}$ & $0.23 \mathrm{~B}$ & $0.21 \mathrm{~B}$ & $<0.001 \mathrm{U}$ & $<0.001 \mathrm{U}$ \\
\hline Cadmium & 80 & $<0.21 \mathrm{U}$ & $<0.21 \mathrm{U}$ & $<0.2 \mathrm{IU}$ & $<0.21 \mathrm{U}$ & $<0.20 \mathrm{U}$ & $<0.002 \mathrm{U}$ & $<0.002 \mathrm{U}$ \\
\hline Chromium & 400 & 9.37 & 11.30 & $8: 18$ & 9.45 & 9.14 & $<0.003 U$ & $<0.003 U$ \\
\hline Lead & 250 & 13.70 & 5.01 & 5.23 & 12.30 & 6.70 & $<0.0022 \mathrm{U}$ & $<0.0023 \mathrm{U}$ \\
\hline Mercury & 24 & $<0.11 \mathrm{UJ}$ & $<0.11 \mathrm{UJ}$ & $<0.11 \mathrm{UJ}$ & $<0.10 \mathrm{UJ}$ & $<0.11 \mathrm{UJ}$ & $<0.0002 \mathrm{UJ}$ & $<0.0002 \mathrm{UJ}$ \\
\hline Nickel & 1600 & 10.30 & 12.30 & 10.30 & 9.89 & 9.88 & $<0.009 \mathrm{U}$ & $<0.009 \mathrm{U}$ \\
\hline Silver & 400 & $0.66 \mathrm{~B}$ & 0.63 & $0.58 \mathrm{~B}$ & $0.48 \mathrm{~B}$ & $0.63 \mathrm{~B}$ & $<0.004 \mathrm{U}$ & $<0.004 \mathrm{U}$ \\
\hline Uranium & $n / a$ & $105.8 \pm 6.4$ & $46.7 \pm 3.4$ & $44.2 \pm 3.1$ & $41.6 \pm 2.9$ & $26.0 \pm 2.1$ & NR & $\mathrm{NR}$ \\
\hline Pentachlorophenol & 8.33 & $<3.50 \mathrm{U}$ & $<3.60 \mathrm{U}$ & $<3.70 \mathrm{U}$ & $<3.50 \mathrm{U}$ & $<3.50 \mathrm{U}$ & NR & $\mathrm{NR}$ \\
\hline Units & $\mathrm{pCi} / \mathrm{gm}$ & $\mathrm{pCi} / \mathrm{gm}$ & $\mathrm{pCi} / \mathrm{gm}$ & $\mathrm{pCi} / \mathrm{gm}$ & $\mathrm{pCi} / \mathrm{gm}$ & $\mathrm{pCi} / \mathrm{gm}$ & $\mathrm{pCi} / \mathrm{gm}$ & $\mathrm{pCi} / \mathrm{gm}$ \\
\hline Uranium-234 & $n / a$ & $34.6 \pm 2.1$ & $15.1 \pm 1$ & $14.7 \pm 1$ & $13.55 \pm 0.96$ & $9 \pm 0.7$ & NR & NR \\
\hline Urasium-235 & $n / a$ & $2.05 \pm 0.32$ & $0.89 \pm 0.18$ & $0.80 \pm 0.16$ & $0.83 \pm 0.17$ & $0.46 \pm 0.12$ & NR & $\mathrm{NR}$ \\
\hline Uranium-238 & $n / a$ & $35.1 \pm 2.1$ & $15.5 \pm 1.1$ & $14.7 \pm 1$ & $13.38 \pm 0.95$ & $8.64 \pm 0.68$ & NR & NR \\
\hline
\end{tabular}


2

$3 \mathrm{n} / \mathrm{a}=$ not applicable

$4 \mathrm{mg} / \mathrm{Kg}=$ milligrams per kilogram (equivalent to parts per million [ppm])

$5 \mathrm{mg} / \mathrm{L}=$ milligrams per liter (equivalent to $\mathrm{ppm}$ )

$6 \mathrm{pCi} / \mathrm{gm}=$ picocuries per gram

7

$\mathrm{NR}=$ Not required by the modified sampling and analysis plan.

Total uranium concentrations were calculated from the isotope concentrations using the following conversion factors:

1.6038 E-4 gram U-234 per pCi U-234

6.62697 E-1 gram U-235 per pCi U-235

2.97493 gram U-238 per pCi U-238

\section{Data Qualifiers:} laboratory. is an estimate.

UR Indicates that the compound or analyte was analyzed for and not detected in the sample. data to be used (Section 6.3). data are usable for decision-making purposes.

B For inorganic data; indicates that the analyte concentration is less than the contract required detection limit, but greater than the instrument detection limits.

$\mathrm{U}$ Indicates that the compound or analyte was analyzed for and not detected in the sample. The value reported is the sample quantitation limit corrected for sample dilution and moisture content by the

UJ Indicates that the compound or analyte was analyzed for and not detected in the sample. Because of a quality control deficiency identified during the data validation, the associated quantitation limit Additionally, the data are unusable due to an identified QC deficiency. Ecology is allowing these

J Indicates that the compound or analyte was analyzed for and detected. Because of a quality control deficiency identified during the data validation, the associated concentration is an estimate, but the 
2 The data from sampling and analysis were validated by Tech Law, Inc. Validation was performed in

3 accordance with Level D as defined in Data Validation Procedures for Chemical Analysis

4 (WHC-SD-EN-SPP-002) and Data Validation Procedures for Radiochemical Analysis

5 (WHC-SD-EN-SPP-001). Level D validation includes evaluation and qualification of results based on 6 analytical holding times, method blank results, matrix spikes and duplicates, surrogate recoveries, and 7 analytical method blanks. The results of the data validation are part of the data validation package

8 (98-EAP-346).

\subsection{DATA QUALIFIERS}

The data validation procedure and the laboratory established the following qualifiers and definitions to describe the data associated with the constituents of concern.

$\mathrm{U}$ indicates that the compound or analyte was analyzed for and not detected in the sample. The value reported is the sample quantitation limit corrected for sample dilution and moisture content.

UJ indicates that the compound or analyte was analyzed for and not detected in the sample. Because of a quality control deficiency identified during the data validation, the associated quantitation limit is an estimate.

UR indicates that the compound or analyte was analyzed for and not detected in the sample. Additionally, the data are unusable because of an identified quality control deficiency.

J indicates that the compound or analyte was analyzed for and detected. The associated concentration is an estimate, but the data are usable for decisionmaking.

B for inorganic data, indicates that the analyte concentration is less than the contract required detection limit, but greater than the instrument detection limits.

\subsection{EXPLANATION OF QUALIFIED DATA}

29 Table 6-1 identifies all analytical results qualified by the data validation process. Table 6-1 is limited to 30 the data qualifications for the constituents of concern and the analysis specified in Section 5.0. The significance of the data qualifiers are discussed in Section 6.3. The qualifiers on Table 6-1 are included with the analytical data on Tables 5-2 and 5-3. Additional information is available in the data validation package (98-EAP-346). Any data qualifiers not listed on Table 6-1 were assigned by the laboratory doing the analysis.

\subsection{ASSESSMENT OF DATA VALIDATION}

37 Specifically, the mercury data for BOMB45 from sample location C3, BOMB46 from sample location C2, 
1 matrix spike analysis. The data from these three samples are unusable for determining if the interior of the 2 303-K Building meets the mercury cleanup performance standard. Note that the mercury data for sample

3 BOMB44 at sample location $\mathrm{Cl}$ are still usable. However, Ecology stated that this is not a critical

4 problem and that the otherwise rejected data can be used to support the clean closure of the interior

5 (DOE-RL and Ecology-1998).

The remainder of the interior samples only had minor deficiencies. The qualifier $J$ was applied to lead in four samples, uranium-235 in one sample, and mercury in one sample. The qualifier UJ was applied to mercury in one sample. The qualifier $\mathrm{U}$ was applied to lead in one sample.

For the exterior (soil) sample data, no major deficiencies were identified during the data validation process that would have qualified the data as unusable. Minor deficiencies were identified in the validation process. The qualified UJ was applied to mercury in all the exterior samples and to pentachlorophenol in one sample. The qualifier $U$ was applied to lead in two samples. The qualifier $J$ was applied to uranium-235 in one sample and to uranium-234 in two samples.

The data qualifiers are included in Tables 5-2 and 5-3. Information on data validation is provided in more detail in the data validation package (98-EAP-346). 
Table 6-1. Data Qualifications Summary Table.

(sheet 1 of 2)

\begin{tabular}{|c|c|c|c|c|c|}
\hline $\begin{array}{l}\text { Constituent of } \\
\text { Concern }\end{array}$ & Type & $\begin{array}{l}\text { Qualifier } \\
\text { Added to } \\
\text { Data }\end{array}$ & Samples Affected & $\begin{array}{l}\text { Data Quality } \\
\text { Objective }\end{array}$ & Reason \\
\hline Mercury & Major & UR & $\begin{array}{l}\text { BOMB45, } \\
\text { BOMB46, } \\
\text { BOMB47 }\end{array}$ & Accuracy & $\begin{array}{l}\text { The recovery for } \\
\text { mercury in the matrix } \\
\text { spike analysis was } 0 \% \\
\text { for BOMB } 44, \text { therefore } \\
\text { the associated non- } \\
\text { detected results were } \\
\text { rejected. }\end{array}$ \\
\hline Uranium-235 & Minor & $\mathrm{J}$ & $\begin{array}{l}\text { BOMB45, } \\
\text { BOM912, } \\
\text { BOM903 }\end{array}$ & $\begin{array}{l}\text { Laboratory } \\
\text { Blanks }\end{array}$ & $\begin{array}{l}\text { Method blank } \\
\text { contamination. }\end{array}$ \\
\hline Uranium-234 & Minor & $\mathrm{J}$ & BOM903 & $\begin{array}{l}\text { Laboratory } \\
\text { Blanks }\end{array}$ & $\begin{array}{l}\text { Method blank } \\
\text { contamination. }\end{array}$ \\
\hline Pentachlorophenol & Minor & UJ & ВОМ902 & $\begin{array}{l}\text { Holding } \\
\text { Time }\end{array}$ & $\begin{array}{l}\text { Sample was analyzed } \\
21 \text { days beyond the } 40 \\
\text { day holding time. }\end{array}$ \\
\hline Lead & Minor & $\mathrm{J}$ & $\begin{array}{l}\text { BOMB44, } \\
\text { BOMB45, } \\
\text { BOMB46, } \\
\text { BOMB47 }\end{array}$ & Precision & $\begin{array}{l}\text { The duplicate relative } \\
\text { percent difference and } \\
\text { serial dilution percent } \\
\text { difference for lead in } \\
\text { BOMB44 was qualified } \\
\text { as an estimate. The } \\
\text { associated samples were } \\
\text { also qualified as } \\
\text { estimates. }\end{array}$ \\
\hline Lead & Minor & U & $\begin{array}{l}\text { BOMB48, } \\
\text { BOMB49, } \\
\text { BOM8Y6 }\end{array}$ & $\begin{array}{l}\text { Laboratory } \\
\text { Blanks }\end{array}$ & $\begin{array}{l}\text { Preparation blank } \\
\text { associated with the } \\
\text { water matrix samples } \\
\text { was contaminated by } \\
\text { lead. }\end{array}$ \\
\hline Mercury & Minor & $\mathrm{J}$ & BOMB44 & Accuracy & $\begin{array}{l}\text { The recovery for } \\
\text { mercury in the matrix } \\
\text { spike analysis was } 0 \% \text {. }\end{array}$ \\
\hline Mercury & Minor & UJ & $\begin{array}{l}\text { BOMB48, BOMB49, } \\
\text { BOM8Y6, BOM8Y7, } \\
\text { BOM8Y9, BOM900, } \\
\text { BOM901, BOM902, } \\
\text { BOM903, BOM904, } \\
\text { BOM905 BOM906, } \\
\text { BOM907, BOM908, } \\
\text { BOM909, BOM910, } \\
\text { BOM911, BOM912, } \\
\text { BOM913, BOM914 }\end{array}$ & $\begin{array}{l}\text { Holding } \\
\text { Time }\end{array}$ & $\begin{array}{l}\text { All analysis occurred } \\
\text { beyond the } 28 \text {-day } \\
\text { holding time. }\end{array}$ \\
\hline
\end{tabular}


$\mathrm{U}$ Indicates that the compound or analyte was analyzed for and not detected in the sample. The value

UJ Indicates that the compound or analyte was analyzed for and not detected in the sample. Because of a quality control deficiency identified during the data validation, the associated quantitation limit is an estimate.

UR Indicates that the compound or analyte was analyzed for and not detected in the sample.

Additionally, the data are unusable because of an identified quality control deficiency.

11 J Indicates that the compound or analyte was analyzed for and detected. The associated concentration is an estimate, but the data are usable for decision making purposes. 


\subsection{STATISTICAL ANALYSIS}

2 All data collected are analyzed and tabulated for evaluation using the methods described in SW-846 and in

3 Appendix F of the closure plan (DOE/RL-90-04).

4

5 - Method accuracy

6 - Method detection limit

7 - Limit of quantitation

- 8 - Total number of samples

9 - Number of less-than-detection-limit samples

10 - Mean

11 - Standard deviation

12 - Coefficient of variation

13 - Method precision

14 - Minimum value

15 - Maximum value

16 - Median value.

\subsection{DATA SETS FOR STATISTICAL ANALYSIS}

To perform a useful statistical analysis, there must be a sufficient number of data points available above the detection limits or the analysis is skewed downward. For this reason, full statistical analysis was not completed on the soil mercury data and soil pentachlorophenol data because all of the values were at the detection limit. The full statistical analysis was not done on the concrete pentachlorophenol data because of only one data point. The detection limit values were used to provide an upper limit to the statistical analysis. The statistical analysis for the soil cadmium data also might be skewed as 10 of the 18 data points were detection limit values. The mathematical equations used in the statistical analysis are included in Appendix E. The statistical analysis for the exterior (soil) data is presented on Table 7-1 and the interior (concrete) data are presented on Table 7-2.

\subsection{METHOD ACCURACY}

Method accuracy for the data is based on the data analysis of matrix spikes and matrix spike duplicates. The method accuracy calculations are done as part of the data validation package (98-EAP-346) and involve constituents that are not included in the constituents of concern. For this reason, the calculations are not being reported as part of the statistical analysis.

The data validation package reported that the goals for method accuracy on the constituents of concern were met except for mercury in the following interior samples: BOMB44, BOMB45, BOMB46, and BOMB47. On these samples, the matrix spike recovery was outside the acceptance criteria. For three of these four samples, this was identified as a major deficiency by the data validation package. Because only one sample produced useable data, the statistical analysis will exclude the interior mercury data. Refer to Table 6-1 and the data validation package for additional information. 
Table 7-1. Exterior (Soil) Data Statistical Analysis.

Beryllium 1 Cadmium Chromium $/$ Lead 1 Mercury

\begin{tabular}{|c|c|c|c|c|c|c|c|c|c|c|}
\hline . & Arsenic & Barium & Beryllium & Cadmium & Chromium & Lead & Mercury & Nickel & Silver & Pentachlorophenol \\
\hline Method Detection Limit ${ }^{1} \mathrm{mg} / \mathrm{kg}$ & 0.33 & 0.11 & 0.11 & 0.22 & 0.34 & 0.22 & 0.11 & 1.00 & 0.45 & NA \\
\hline $\begin{array}{l}\text { Limit of Quantitation }{ }^{2} \\
\mathrm{mg} / \mathrm{kg}\end{array}$ & NA & $\mathrm{NA}$ & NA & NA & NA & NA & NA & NA & $\mathrm{NA}$ & 3.7 \\
\hline Total Number of Samples & 18 & 18 & 18 & 18 & 18 & 18 & 18 & 18 & 18 & 18 \\
\hline $\begin{array}{l}\text { Number of less than detection } \\
\text { limit samples }\end{array}$ & 0 & 0 & 0 & 10 & 0 & 0 & 18 & 0 & 3 & 18 \\
\hline $\begin{array}{l}\text { Sufficient number of samples for } \\
\text { a statistical analysis? }\end{array}$ & $\mathrm{Y}$ & $\mathrm{Y}$ & $\mathrm{Y}$ & $\mathrm{Y}$ & $\mathrm{Y}$ & $\mathrm{Y}$ & $\mathrm{N}$ & $\mathrm{Y}$ & $\mathrm{Y}$ & $\mathrm{N}$ \\
\hline $\begin{array}{l}\text { Mean } \\
\mathrm{mg} / \mathrm{kg}\end{array}$ & $2: 41$ & 98.04 & 0.22 & 0.29 & 14.08 & 10.24 & NA & 22.07 & 0.68 & NA \\
\hline $\begin{array}{l}\text { Standard Deviation } \\
\mathrm{mg} / \mathrm{kg}\end{array}$ & 0.44 & 47.83 & 0.04 & 0.13 & 8.66 & 5.53 & NA & 33.57 & 0.41 & NA \\
\hline Coefficient of Variation & 0.18 & 0.49 & 0.18 & 0.45 & 0.62 & 0.54 & NA & 1.52 & 0.60 & NA \\
\hline $\begin{array}{l}\text { Method S6 \& S6 Duplicate } \\
\text { Precision }\end{array}$ & 10.73 & 14.55 & 6.9 & 18.18 & 1.57 & 31.69 & 9.52 & 65.62 & 99.42 & 0.00 \\
\hline $\begin{array}{ll}\text { as RPD } & \text { S10 \& S10 } \\
\text { Duplicate }\end{array}$ & 34.85 & 22.78 & 28.57 & 4.65 & 8.53 & 49.10 & 20.00 & 11.98 & 20.83 & 0.00 \\
\hline $\begin{array}{l}\text { S11 Lower \& S11 } \\
\text { Lower Duplicate }\end{array}$ & 13.06 & 6.06 & 8.70 & 0.00 & 32.03 & 4.3 & 0.00 & 17.70 & 8.26 & 2.74 \\
\hline $\begin{array}{l}\text { Minimum Value } \\
\mathrm{mg} / \mathrm{kg}\end{array}$ & 1.87 & 58.4 & 0.14 & 0.20 & 8.18 & 4.81 & NA & 9.02 & 0.41 & $\mathrm{NA}$ \\
\hline $\begin{array}{l}\text { Maximum Value } \\
\mathrm{mg} / \mathrm{kg}\end{array}$ & 3.41 & 266 & 0.28 & 0.68 & 22.5 & 22.5 & NA & 150 & 2.05 & NA \\
\hline $\begin{array}{l}\text { Median } \\
\mathrm{mg} / \mathrm{kg}\end{array}$ & 2.38 & 84.5 & 0.23 & 0.22 & 3.97 & 7.82 & NA & 11.6 & 0.56 & NA \\
\hline $\begin{array}{l}\text { CLEANUP PERFORMANCE } \\
\text { STANDARD } \\
\text { mg/kg }\end{array}$ & 9.18 & 5600 & 1.81 & 80 & 400 & 250 & 24 & 1600 & 400 & 8.33 \\
\hline
\end{tabular}

${ }_{2}^{1}$ The method detection limit is sample specific. For the analysis indicated, the highest method detection limits are presented.

${ }^{2}$ The limit of quantitation is sample specific. For the analysis indicated, the limit of quantitation is presented.

$\mathrm{mg} / \mathrm{kg}=$ milligrams per kilogram

$\mathrm{NA}=$ not applicable

$\mathrm{RPD}=$ relative percent difference

$\mathrm{Y}=$ yes

$10 \quad \mathrm{~N}=$ no

II 
Table 7-2. Interior (Concrete) Data Statistical Analysis.

\begin{tabular}{|c|c|c|c|c|c|c|c|c|c|c|c|c|c|}
\hline & $\mathrm{Ar}$ & $\mathrm{Ba}$ & $\mathrm{Be}$ & Cd & $\mathrm{Cr}$ & $\mathrm{Pb}$ & $\mathrm{Hg}$ & $\mathrm{Ni}$ & $\mathrm{Ag}$ & $\mathrm{Cl}$ & NO3 & $\mathrm{NO} 2$ & PCP \\
\hline Method Detection Limit ${ }^{1} \mathrm{mg} / \mathrm{kg}$ & 0.30 & 0.10 & 0.10 & 0.20 & 0.30 & 0.20 & 0.095 & 0.90 & 0.40 & 0.11 & 0.034 & 0.034 & NA \\
\hline $\begin{array}{l}\text { Limit of Quantitation } \\
\mathrm{mg} / \mathrm{kg}\end{array}$ & NA & NA & NA & NA & $\mathrm{NA}$ & NA & NA & NA & $\overline{N A}$ & $\mathrm{NA}$ & NA & $\mathrm{NA}$ & 3.3 \\
\hline Total Number of Samples & 4 & 4 & 4 & 4 & 4 & 4 & 4 & 4 & 4 & 4 & 4 & 4 & 1 \\
\hline $\begin{array}{l}\text { Number of less than detection } \\
\text { limit samples }\end{array}$ & 0 & 0 & 0 & 0 & 0 & 0 & 3 & 0 & 1 & 0 & 0 & 0 & 1 \\
\hline $\begin{array}{l}\text { Sufficient number of samples for } \\
\text { a statistical analysis? }\end{array}$ & $\bar{Y}$ & $\mathrm{Y}$ & $Y$ & $\mathrm{Y}$ & $Y$ & $\mathrm{Y}$ & $\mathrm{N}$ & $\mathrm{Y}$ & $\mathrm{Y}$ & $Y$ & $\mathrm{Y}$ & $Y$ & $\mathrm{~N}$ \\
\hline $\begin{array}{l}\text { Mean } \\
\mathrm{mg} / \mathrm{kg}\end{array}$ & 3.82 & 217.4 & 0.27 & 1.92 & 22.58 & 190.5 & 0.25 & 17.71 & 1.27 & 99.5 & 4.62 & 3.24 & $\mathrm{NA}$ \\
\hline $\begin{array}{l}\text { Standard Deviation } \\
\mathrm{mg} / \mathrm{kg}\end{array}$ & 1.83 & 80.99 & 0.04 & 1.31 & 4.82 & 141.2 & $\mathrm{NA}$ & 7.71 & 1.18 & 43.1 & 1.82 & 4.72 & NA \\
\hline Coefficient of Variation & 0.48 & 0.37 & 0.16 & 0.68 & 0.21 & 0.74 & $\mathrm{NA}$ & 0.44 & 0.93 & 0.43 & 0.39 & 1.46 & $\mathrm{NA}$ \\
\hline $\begin{array}{l}\text { Method Precision As RPD } \\
\text { (C2 \& C2 Duplicate) }\end{array}$ & 3.41 & 11.54 & 11.76 & 59.52 & 22.31 & 59.19 & 0.0 & 26.98 & 53.01 & 12.90 & 6.59 & 13.33 & $\mathrm{NA}$ \\
\hline $\begin{array}{l}\text { Minimum Value } \\
\mathrm{mg} / \mathrm{kg}\end{array}$ & 2.85 & 97.4 & 0.24 & 0.31 & 16.20 & 4.91 & 0.09 & 8.12 & 0.38 & 36 & 2.08 & 0.40 & $\mathrm{NA}$ \\
\hline $\begin{array}{l}\text { Maximum Value } \\
\mathrm{mg} / \mathrm{kg}\end{array}$ & 6.57 & 275 & 0.33 & 3.51 & 28.90 & 311 & 0.49 & 23.35 & 2.99 & 132 & 6.11 & 10.3 & NA \\
\hline $\begin{array}{l}\text { Median } \\
\mathrm{mg} / \mathrm{kg}\end{array}$ & 2.93 & 263.5 & 0.24 & 1.92 & 22.6 & 233 & 0.10 & 18.10 & 1.66 & 36 & 5.14 & 1.13 & NA \\
\hline $\begin{array}{l}\text { CLEANUP PERFORMANCE } \\
\text { STANDARD } \\
\mathrm{mg} / \mathrm{kg}\end{array}$ & 9.18 & 5600 & 1.81 & 80 & 400 & 250 & 24 & 1600 & 400 & 8000 & 541.2 & 128000 & 8.33 \\
\hline
\end{tabular}

$3{ }^{1}$ The method detection limit is sample specific. For the analysis indicated, the highest method detection limits are presented.

$4{ }^{2}$ The limit of quantitation is sample specific. For the analysis indicated, the limit of quantitation is presented.

$\mathrm{Ar}=$ arsenic; $\mathrm{Ba}=$ barium; $\mathrm{Be}=$ beryllium; $\mathrm{Cd}=$ cadmium; $\mathrm{Cr}=$ chromium; $\mathrm{Pb}=$ lead; $\mathrm{Hg}=$ mercury; $\mathrm{Ni}=$ nickel; $\mathrm{Ag}=$ silver PCP = pentachlorophenol

$\mathrm{mg} / \mathrm{kg}=$ milligrams per kilogram

NA = not applicable

$\mathrm{RPD}=$ relative percent difference

$\mathrm{Y}=$ yes

$13 \quad \mathrm{~N}=$ no 
HNF-2959

1

2

3

4

5

This page intentionally left blank. 
2 The closure plan (DOE/RL-90-04) requires an evaluation of the analytical data to determine if the

3 constituents of concern are above the cleanup performance standards. The 303-K Storage Facility is

4 divided into the following two components for the data evaluation:

5

6 - The interior consisting of the concrete floor and ceiling

7 - The exterior consisting of the soil.

8

9 These two components are evaluated separately against the requirements for closure.

\subsection{EVALUATION OF THE INTERIOR CONCRETE SAMPLE DATA}

11 The analytical data for the interior concrete sampling are presented on Table 5-2. The statistical analysis 12 of the analytical data is presented on Table 7-2.

\section{3. $\quad$ 8.1.1 Metals Analysis and Data}

14 Table 8-1 compares the method detection limits for the metals in the concrete to the permit requirements.

15 All of the metals analysis method detection limits met the requirement to be equal to or less than $1 / 10$ of the value for the cleanup performance standard. Except for the $\mathrm{C} 2, \mathrm{C} 2$ duplicate, and $\mathrm{C} 3$ mercury data, all other metals data met the data validation requirements for acceptability. Ecology has determined that the mercury data from locations $\mathrm{C} 2, \mathrm{C} 2$ duplicate, and $\mathrm{C} 3$ can be used in the data evaluation (98-EAP-346). Therefore, all of the metals data are useable for the evaluation.

For the concrete, the data in Table 5-2 show that one metal constituent of concern (lead) has values above the cleanup performance standard and all other metals constituents of concern are below the cleanup performance standard. The lead values for locations $\mathrm{C} 1$ and $\mathrm{C} 2$ duplicate are 311 milligrams per kilogram and 289 milligrams per kilogram. The cleanup performance standard is 250 milligrams per kilogram. Both these locations are from the interior trench. The lead value at sample location $\mathrm{C} 2$ is 157 milligrams per kilogram. In contrast, the single sample location from the ceiling, $\mathrm{C} 3$, is only 4.91 milligrams per kilogram.

For arsenic, the highest value is less than cleanup performance standard. All arsenic values are the same order of magnitude as the cleanup performance standard. For barium, beryllium, cadmium, and chromium, the maximum concentrations are 1 order of magnitude less than the cleanup performance standard. For mercury, nickel, and silver, the maximum concentrations are 2 orders of magnitude less than the cleanup performance standard. These differences are sufficiently great that there are no statistical concerns related to the data. The uranium data on Table 5-2 are provided for information purposes only.

\subsubsection{Inorganic Anion Analysis and Data}

36 Table 8-1 compares the method detection limits for the anions in the concrete to the permit requirements. 
performance standard. All anion data met the data vàlidation requirements for acceptability. The data are useable for the evaluation.

For the concrete, the data on Table 5-2 show that all of the anion constituent of concern are below the cleanup performance standards. For the chloride ion, the maximum concentration is 3 orders of magnitude less than the cleanup performance standard. For the nitrate ion, the maximum concentration is 2 orders of magnitude less than the cleanup performance standard. For the nitrite ion, the maximum concentration is 6 orders of magnitude less than the cleanup performance standard. These differences are sufficiently great that there are no statistical concerns related to the data.

\subsubsection{Semivolatile Organic Analysis and Data}

Table 8-1 compares the method quantitation limit for the semivolatile organic in the concrete to the permit requirement. The method quantitation limit met the requirement to be equal to or less than the value for the cleanup performance standard. All semivolatile organic data met the data validation requirements for acceptability. The data are useable for the evaluation.

For concrete, the data on Table 5-2 show that the concentration of pentachlorophenol is below the cleanup performance standard. The value for pentachlorophenol is of the same magnitude as the cleanup performance standard. This is not a concern because the pentachlorophenol value is also below the method detection limit.

\subsubsection{Conclusion: Concrete}

Based on the information presented, there is lead contamination above the cleanup performance standard in the interior trench. There is no lead contamination on the interior ceiling. All other interior metals constituents of concern are below the cleanup performance standard. All anion constituents of concern are below the cleanup performance standard. The semivolatile organic constituent of concern is not present in the building interior.

\subsection{EVALUATION OF THE SOLL}

The inorganic analytical data for the soil are presented on Table 5-3. The statistical analysis of the analytical data is presented on Table 7-1.

\subsubsection{Metals Analysis and Data}

Table 8-1 compares the method detection limits for the metals in the soil to the permit requirements. All method detection limits met the requirement to be equal to or less than $1 / 10$ of the value for the cleanup performance standard. All soil metals data met the data validation requirements for acceptability. All of the metals data are useable for the evaluation.

For the soil, the data in Table 5-3 show that all metals constituents of concern are below the cleanup performance standard. For beryllium, the maximum concentration is 1 order of magnitude less than the cleanup performance standard. For barium, cadmium, chromium mercury, and nickel, the maximum 
concentrations are 2 orders of magnitude less than the cleanup performance standard. For silver, the maximum concentration is 4 orders of magnitude less than the cleanup performance standard. These differences are sufficiently great that there are no statistical concerns related to the data. The uranium data on Table 5-3 are provided for information purposes only.

\subsubsection{Semivolatile Organic Analysis and Data}

6 Table 8-1 compares the highest method quantitation limit for semivolatile organic in the concrete to the permit requirement. The method quantitation limit met the requirement to be equal to or less than the value for the cleanup performance standard. All semivolatile organic data met the data validation requirements for acceptability. The data are useable for the evaluation.

For soils, the data on Table 5-3 show that the concentration of pentachlorophenol is below the cleanup performance standard. The values for pentachlorophenol are of the same magnitude as the cleanup performance standard. This is not a concern because the pentachlorophenol values are also below the method detection limit.

\subsubsection{Conclusion: Soil}

16 Based on the information presented, there are no metals constituents of concern present in the soil above the cleanup performance standards. The semivolatile organic constituent of concern is not present in the soil.

\subsection{EQUIPMENT AND FIELD BLANK ANALYTICAL RESULTS}

19 The analytical data for the concrete and soil sampling equipment blanks are presented on Tables 5-2 and $205-3$, respectively.

For all interior (concrete sampling) equipment blanks, the values for arsenic, beryllium, cadmium, chromium, lead, mercury, nickel, and silver are below detection limit values. However, a very low level of barium $(0.0025$ milligram per kilogram) was detected. There would not be any adverse affects on the data because the barium concentration in the equipment blank is 6 orders of magnitude less than the lowest barium concentration ( 97.40 milligram per kilogram) in the concrete.

For all exterior (soil sampling) equipment blanks, the values for the metals (arsenic, barium, beryllium, cadmium, chromium, lead, mercury, nickel, and silver) are below the detection limit values.

The data from the equipment blanks indicate that there is nothing that would affect the $303-\mathrm{K}$ Storage Facility sampling data or any conclusions drawn from that data.

\section{$33 \quad 8.4$ SUMMARY}

34 Based on the evaluation of the analytical data, the following conclusion for the interior can be made. 
1 - There is lead contamination in the trench inside the 303-K Building.

- No other metal constituents of concern (arsenic, barium, beryllium, cadmium, chromium, mercury, nickel, and silver) are present above the cleanup performance standards.

- None of the anion constituents of concern (chloride ion, nitrate ion, nitrite ion) are present above the cleanup performance standard.

- The semivolatile organic constituent of concern is not present inside the 303-K Building.

Based on the evaluation of the analytical data, the following conclusion for the soils can be made.

- None of the metal constituents of concern (arsenic, barium, beryllium, cadmium, chromium, lead, mercury, nickel, and silver) are present in the soils above the cleanup performance standards.

- None of the anion constituents of concern (chloride ion, nitrate ion, nitrite ion) are present in the soils above the cieanup performance standard.

- The semivolatile organic constituent of concern is not present in the soils. 
Table 8-1. Comparison Of Method Detection Limit and Method Quantitation Limit Requirements. Criteria for acceptable data per Permit Condition V.14.B.g.7:

The MQL must be equal to or less than the cleanup OR

The MDL must be 10 times below the cleanup level.

For this evaluation, the highest MDL or MQL for any given media and constituent of concern is used.

\begin{tabular}{|c|c|c|c|c|c|c|}
\hline $\begin{array}{l}\text { Sample } \\
\text { Media }\end{array}$ & $\begin{array}{l}\text { Constituent of } \\
\text { Concern }\end{array}$ & $\begin{array}{c}\text { Met } \\
\text { requirement }\end{array}$ & $\begin{array}{c}\text { Cleanup } \\
\text { Level } \\
(\mathrm{mg} / \mathrm{kg})\end{array}$ & $\begin{array}{c}\mathrm{MQL} \\
(\mathrm{mg} / \mathrm{kg})\end{array}$ & $\begin{array}{c}1 / 10 \\
\text { Cleanup } \\
\text { Level } \\
(\mathrm{mg} / \mathrm{kg})\end{array}$ & $\begin{array}{c}\mathrm{MDL} \\
(\mathrm{mg} / \mathrm{kg})\end{array}$ \\
\hline \multirow[t]{13}{*}{ Concrete } & Arsenic & YES & 9.18 & $\mathrm{NA}$ & 0.918 & 0.30 \\
\hline & Barium & YES & 5600 & NA & 560 & 0.10 \\
\hline & Beryllium & YES & 1.81 & $\mathrm{NA}$ & 0.181 & 0.10 \\
\hline & Cadmium & YES & 80 & $\mathrm{NA}$ & 8.0 & 0.20 \\
\hline & Chromium & YES & 400 & $\mathrm{NA}$ & 40 & 0.30 \\
\hline & Lead & YES & 250 & $\mathrm{NA}$ & 25 & 0.20 \\
\hline & Mercury & YES & 24 & NA & 2.4 & 0.095 \\
\hline & Nickel & YES & 1600 & NA & 160 & 0.90 \\
\hline & Silver & YES & 40 & NA & 40 & 0.40 \\
\hline & Chloride ion & YES & 54.12 & NA & 54.12 & 0.11 \\
\hline & Nitrate ion & YES & 128000 & NA & 12800 & 0.034 \\
\hline & Nitrite ion & YES & 8000 & NA & 800 & 0.034 \\
\hline & PCP & YES & 8.33 & 3.7 & 0.833 & NA \\
\hline \multirow[t]{10}{*}{ Soil } & Arsenic & YES & 9.18 & NA & 0.918 & 0.33 \\
\hline & Barium & YES & 5600 & NA & 560 & 0.11 \\
\hline & Beryllium & YES & 1.81 & NA & 0.181 & 0.11 \\
\hline & Cadmium & YES & 80 & NA & 8.0 & 0.22 \\
\hline & Chromium & YES & 400 & NA & 40 & 0.34 \\
\hline & Lead & YES & 250 & $\mathrm{NA}$ & 25 & 0.22 \\
\hline & Mercury & YES & 24 & NA & 2.4 & 0.11 \\
\hline & Nickel & YES & 1600 & NA & 160 & 1.00 \\
\hline & Silver & YES & 40 & NA & 40 & 0.45 \\
\hline & PCP & YES & 8.33 & 3.7 & 0.83 & $\mathrm{NA}$ \\
\hline
\end{tabular}

$2 \mathrm{MDL}=$ method detection limit

$3 \mathrm{MQL}=$ method quantitation limit

$4 \quad \mathrm{PCP}=$ pentachlorophenol

$5 \mathrm{mg} / \mathrm{kg}=$ milligrams per kilograms

$6 \quad \mathrm{NA}=$ not available 
HNF-2959

1
2
3
4
5

This page intentionally left blank. 


\subsection{CONCLUSIONS}

2 The basic requirement for the clean closure of the 303-K Storage Facility is to have all the constituents of 3 concern below the cleanup performance standards (Table 1-1).

The analytical data show that this requirement has been met for the exterior at the 303-K Storage Facility. The soils can be clean closed per the requirements of WAC 173-303-610. Any metals constituents of concern present in the soil are below the cleanup performance standards. No organic constituents of concern are present in the soil.

The analytical data show that this requirement has not been met for the interior of the 303-K Storage Facility. There is lead contamination in the interior trench. No lead contamination was found on the ceiling. Any other metals and all anion constituents of concern present inside are below the cleanup performance standards.

The entire 303-K Facility cannot be clean closed without additional work. The soil can be clean closed and the 303-K Storage Facility unit boundary can be reduced to the 303-K Building. As a minimum, the additional work required to reach clean closure will include decontaminating the trench until sample results indicate the lead concentration is below the 250 milligrams per kilogram cleanup performance standard.

An additional evaluation beyond this report will be needed to determine how closure of the interior of the $21 \quad 303-K$ Storage Facility will be achieved. 
HNF-2959

1
2
3
4
5

This page intentionally left blank. 


\subsection{REFERENCES}
97-EAP-606, Letter, J. E. Rasmussen, DOE-RL, to J. J. Wallace, Ecology, TRANSMITTAL OF THE ERRATA SHEET FOR THE 303-KS STORAGE FACILITY SAMPLING AND ANALYSIS PLAN (S-3-1), dated August 1, 1997.

98-EAP-145, Letter, J. E. Rasmussen, DOE-RL, to L. J. Cusack, Ecology, TRANSMITTAL OF THE RAW DATA PACKAGE FROM SAMPLING AT THE 303-K STORAGE FACILITY (S-3-1), dated March 10, 1998.

98-EAP-346, Letter, J. E. Rasmussen, DOE-RL, to L. J. Cusack, Ecology, TRANSMITTAL, OF THE VALIDATED DATA FROM SAMPLING AT THE 303-K STORAGE FACILITY (S-3-1), dated July 15, 1998.

DOE/RL-90-04, 303-K Storage Facility Closure Plan, Rev 2A, U.S. Department of Energy, Richland Operations Office, Richland, Washington.

DOE/RL-92-24, Hanford Site Background: Part 1, Soil Background for Nonradioactive Analytes, Rev. 2, U.S. Department of Energy, Richland Operations Office, Richland, Washington.

DOE/RL 94-71, Hanford Site Background Data Applications Guide: Part 1, Soil, Rev. 0, U.S. Department of Energy, Richland Operations Office, Richland, Washington.

DOE-RL and Ecology, 1997, 303-K Storage Facility Project Managers Meeting Minutes, dated November 6, 1997 .

DOE-RL and Ecology, 1998, 303-K Storage Facility Project Managers Meeting Minutes, dated July 9, 1998.

Ecology, EPA, and DOE, 1996, Hanford Federal Facility Agreement and Consent Order, 2 vols., Washington State Department of Ecology, U.S. Environmental Protection Agency, and U.S. Department of Energy, Olympia, Washington.

Ecology, 1994, Dangerous Waste Portion of the Resource Recovery and Conservation Act Permit for the Treatment, Storage, and Disposal of Dangerous Waste, Permit Number WA7890008967, Revisions 3A and 4A, Washington State Department of Ecology, Olympia, Washington.

Ecology, 1997, Letter, Michael Wilson, Ecology to John Wagoner, DOE-RL, Henry Hatch, FDH, Steve Liedle, BHI, Dr. William J. Madia, Pacific Northwest National Laboratory, Permit Modification Letter, 9757627 A, dated August 13, 1997.

HNF-SD-ENV-AP-005, 303-K Storage Facility Sampling and Analysis Plan, Rev. 0, Waste Management Federal Services of Hanford, Inc., Richland, Washington, 1997.

SW-846, Test Methods for the Evaluation of Solid Waste: Physical/Chemical Methods, as amended, U.S. Environmental Protection Agency, Washington, D.C. 
HNF-2959

WHC-SD-EN-SPP-001, Data Validation Procedures for Radiochemical Analyses, Rev. 1, Westinghouse Hanford Company, Richland, Washington, 1993.

3

WHC-SD-EN-SPP-002, Data Validation Procedures for Chemical Analyses, Rev. 2, Westinghouse Hanford Company, Richland, Washington, 1993. 
HNF-2959

1

2
APPENDIX A

SAMPLER'S FIELD LOG 
HNF-2959

1

2

3

4

5

This page intentionally left blank. 
CT 303-K RCRA Chacneterization

Notebook No. WMA - SML - H7

Continued From Page $N / A$

Project \#/Taxk onder : 772030 /.22=026-0o1 Date: $10-29-97$ to

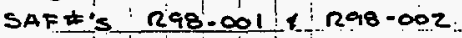

$10-30-97$

Customar: Jason Adler: Environmental Enginneier, Waste Manogement Hanforel

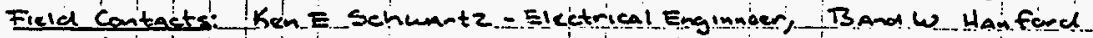

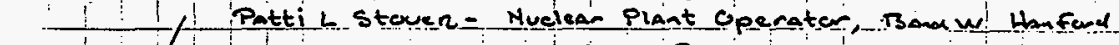

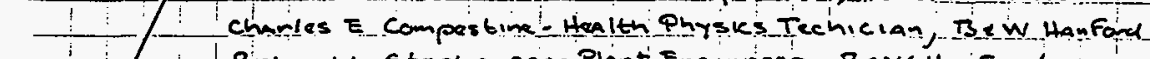

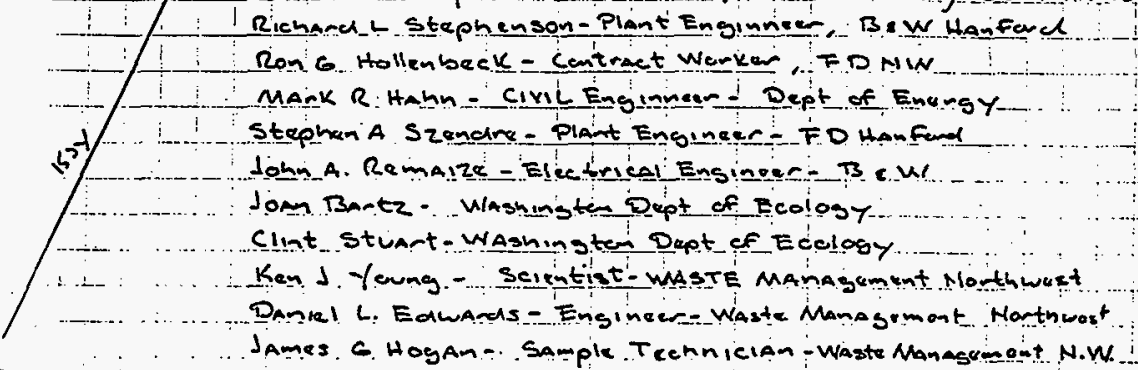
Rompese; : RCRA Closune

Locaticn: $303-K$ BiD6, 300 Area.

Weather Conditiens. 10-29-97...55\%., Cloudy, No uind

$10-30-97,62^{\circ} F$, crincast f raining, wind gust to 45

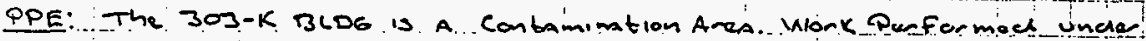
RuP $V-0 G 1$. Full Set of Anti-C's requirace.

Mlonk Done To RERA Protocol

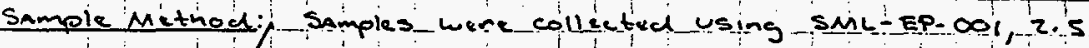
cleanici_stinless sterel, bouls, spoons, Ausers,

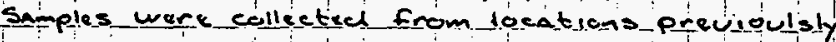
selictxce. Soll Sompies were ichentifind with numbers si thewsh siz, Concrate samples mare

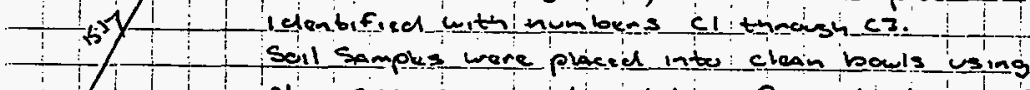

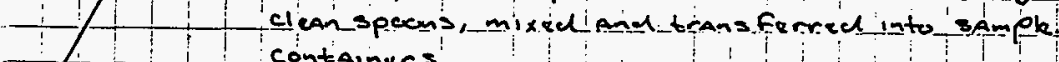
contsinues. 
PPFOJECT $303-K$ RCRA ChNCACterization

Notedook No. WM-DML $=-1+7$

\section{Soll Sample Locations} Continued From Page _ـ 6

\section{proe}

Attaknments $i$ on this

pase.

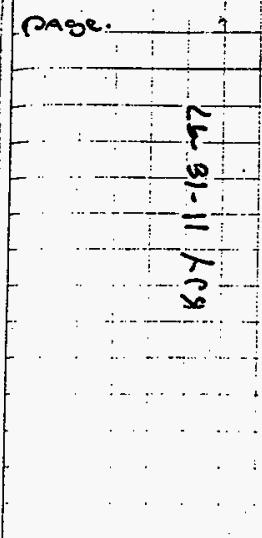

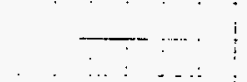

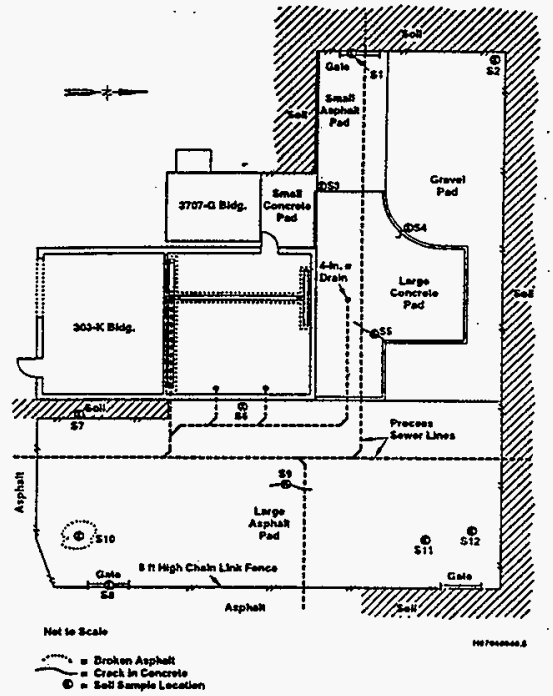

$1 \% \partial Y-11=15-97$ _. 
JECT 303-K" RERA ChArACtarizAtion

Notebook No. WM $=$ SML- H 7

Continued From Page $\ldots$

Two

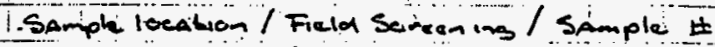

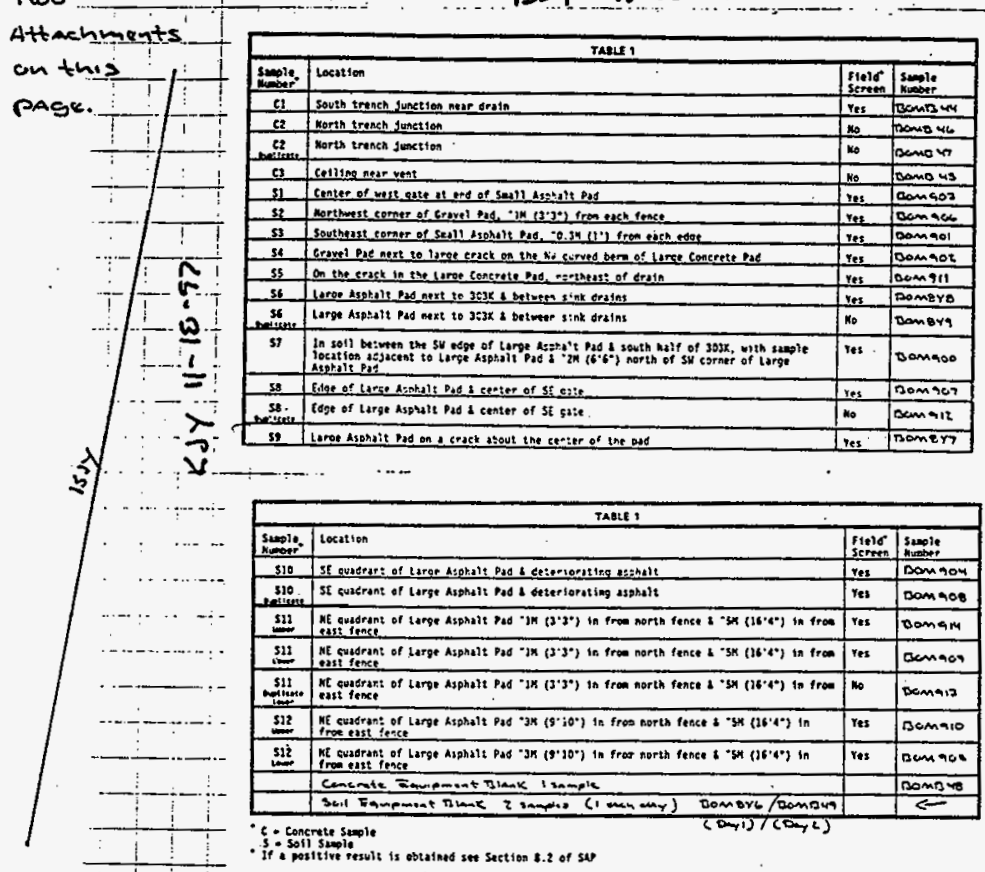

b) $11-18-97$

Quality Centrol sameles:

Two types of qunlity centrol_samples_ware-cellected

1) Drplucate samples: $c 2$, s6, sie, s10, sil Lenar,

2) towpent blanks ... (1 kach on y of sampling $)=z$ Equpment blanks_ware taken first by pauking ASTM bypk II wate cine sampling equpmost inbo A sampling boul to minse all surfaces. Vonder certified clean betties were tmen filled by peuring water into the bottles. ! I Continued on Page 9

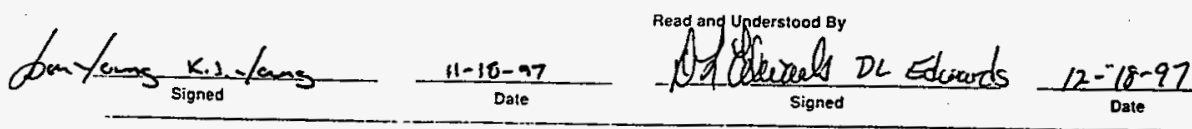




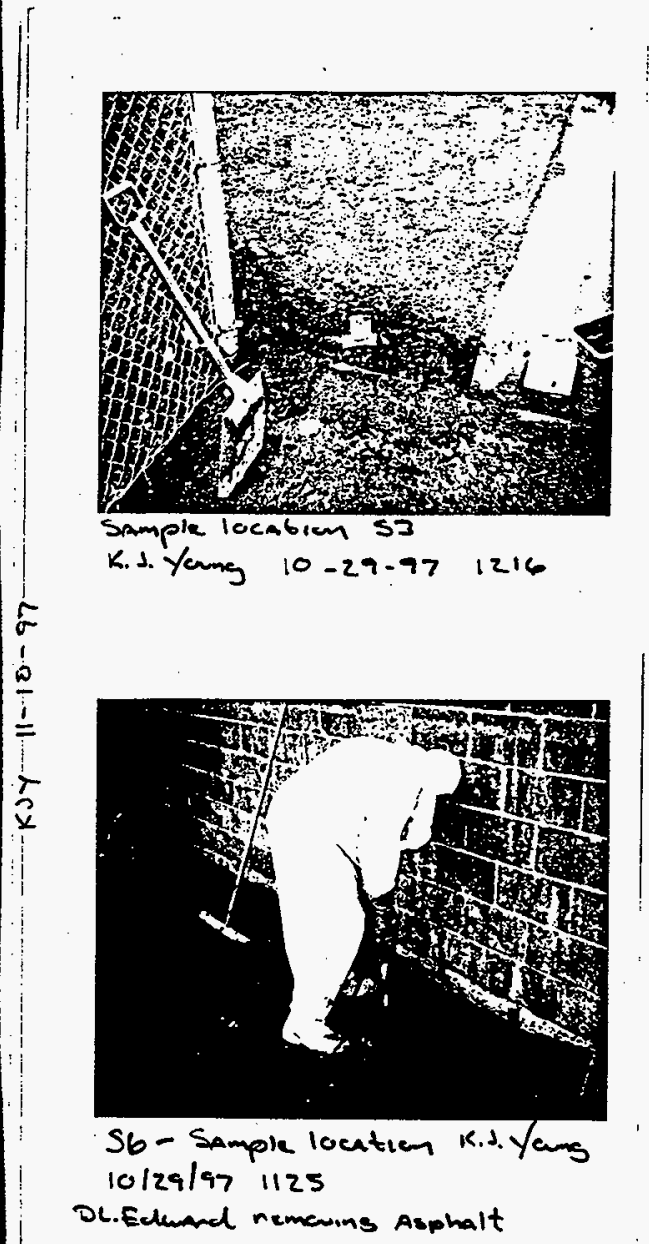

Fer Photos Attrached on this pagr.

\section{bJy $11-18-97$}

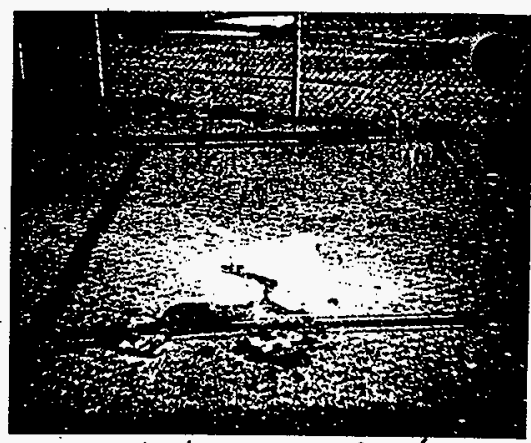

S10- 10/30/97 1010 K.J.Yang Sample locations

$$
\text { sample + duplicate }
$$

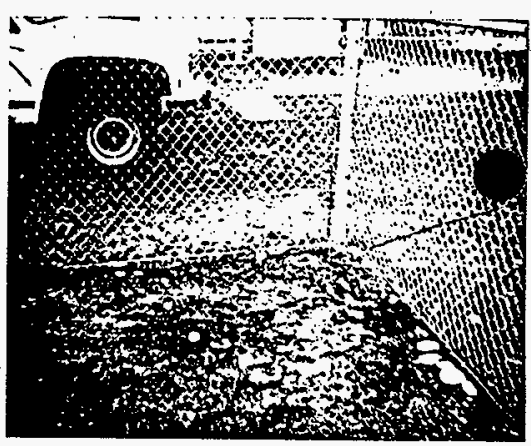

S2- Sample location K.J.V/ang $10 / 29 / 971145$

Nul cernen of oratel Pad

$$
\text { KJY } 11-1 \varepsilon-9\rangle
$$

Denyourg

ik.1. Yang

$11-18-97$

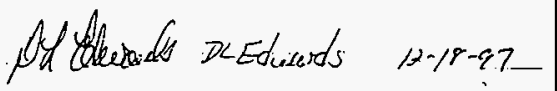


10

PROJECT 303-K RCRA Characterization .....

$$
\text { WM-sMc }-47
$$

Sent Sample Collection: The first 1 to 2 inches of sol At rack location was remarked. Samples wing tron collected for sample locations SI thrash S9 6 inches cheep (upper). Soil from sample locations 510 , SI, F SIR was collected from the upper level And Additional from another six incl's deep (lower) level.

Concrete Sample. Collection: Concrete was collected from the throe locations by chiseling the surface of the collection AreA

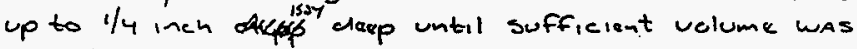
collected. Lection $<3$ was collected in the same manner using poly bags to collect the concrete thins as the pieces were removed from the ceiling.

Mete: A Chisel was Also used to remove asphalt which existed cen some soil sample lceatiens. In each case a clean bit was usa.

fol $11-15-57$
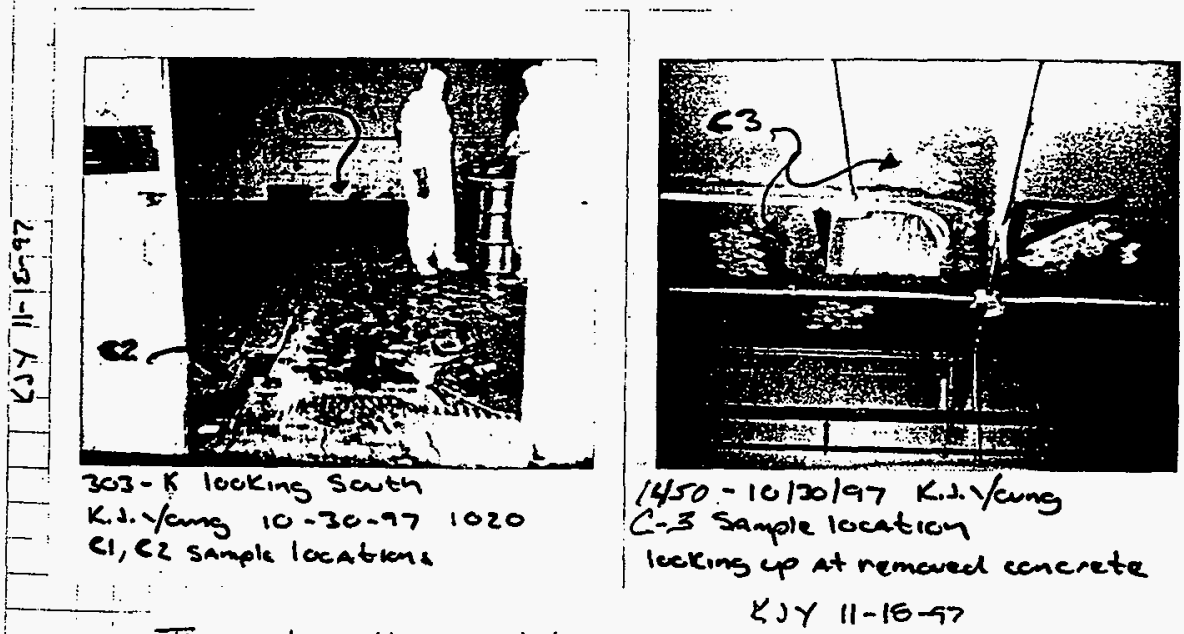

Two photos attached this pase.

1)

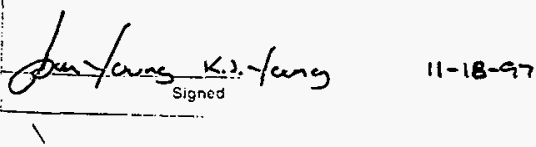

Artedureats

DCEdwerds

$0-15-97$ 
PROJECT 303-K RCRA ChArACterRAtion

Notebook No. WM- SML-HT

Continued From Page 10

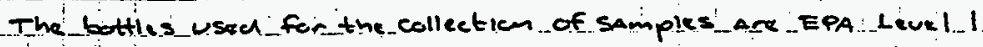
certified ( by the undien). The sizes. of bottles And lot \#.'s for eacm sample locition are:

$125 \mathrm{~mL}$ porywik mouth L4 41230040

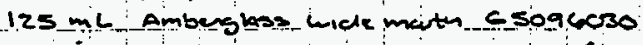
sooml pely-mede mentn L $70090 z 0^{\prime}$ (cemerets

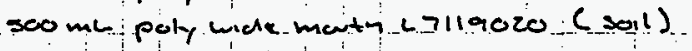

For rad analy!s at the wate sampling e chaipcterization Facility (WuscF) the lab requested a zoni pely bottic And do not haw let or serial numbers.

Washingten Depaitment of Eeolesy: requested split samples be taken fer anaylsis at there lab. Ecolegy prewelk there cun bottles.

All sampies cellected (inelueling Ecelesy split samples) were stemed in the refiriserated / custedy lexked storase area at the 6269. building until raed results were cempleted at WSCF.

Fielel Sergening: Fixld sereoning was dene fem Puntachlorophenol by Immunoassay using sw.E46 methad 4010.

Two RISe PENTA Senil test kits (itum neeos) wro puremeed from: Stratigie Diasnceztics, Ine spoe Binch W/est. Teucer, Suite 4000 .

Hempont Beach, CA 92660

Att: Sinrean Polsky, Client. Serwek Manger.

lot.number 742227 _expinticachte...2/98

If PCP_WAs fund to pee present by fivld sereving than samples fer semivolatile organics wenlel be sent into the lab fer anaty $\rightarrow 3$ by su=846 mxthed 8270 Continued on Page 12

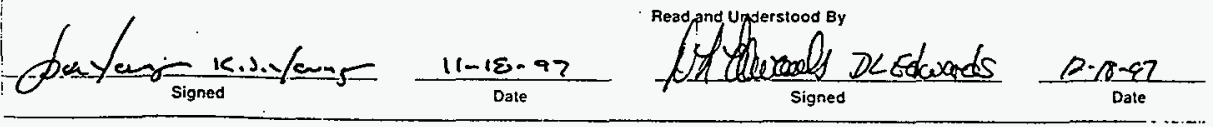




\section{$-[3-b]-\ell \mid$ \\ pau6!s \\ $\frac{\text { aieo }}{6-(3)-11}$

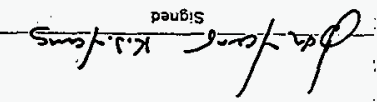

Ei ased uo panumuos

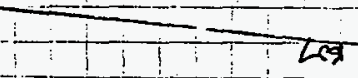

$Y \exists I$ \#

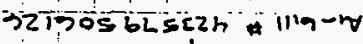

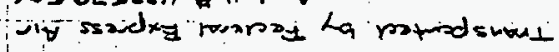

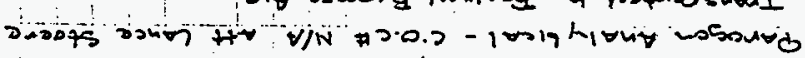

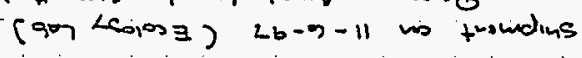

Lss-ins $\mathrm{H}$-200?

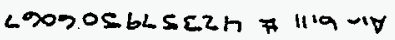

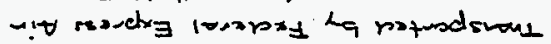

$L-200-3 b v / z-200 \div 3 b v / 2-200-3 b v$

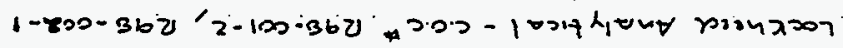

Lb-h-11 m +mondins

Lh2 - smo 7 rimos

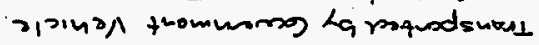

$$
\begin{aligned}
& \text { s- } 200-362
\end{aligned}
$$

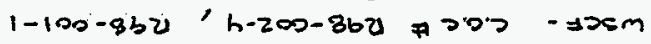

$$
\begin{aligned}
& \text { Lb-IE-OI vis salemito }
\end{aligned}
$$

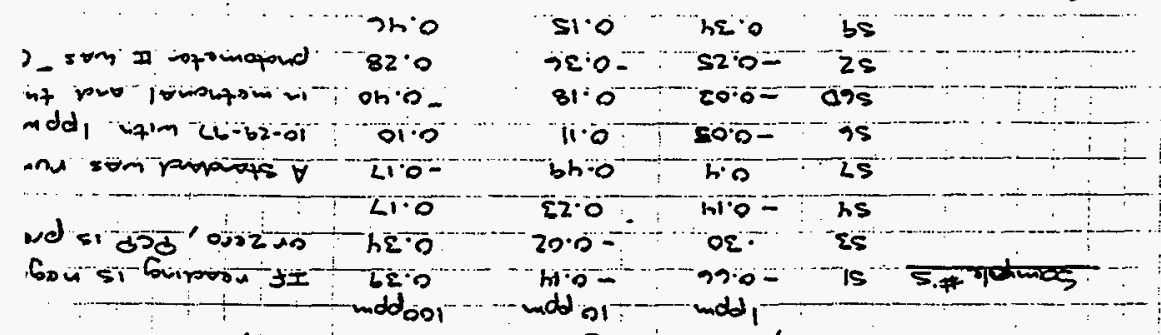

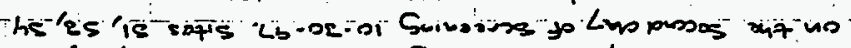

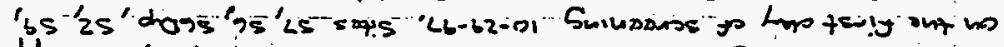

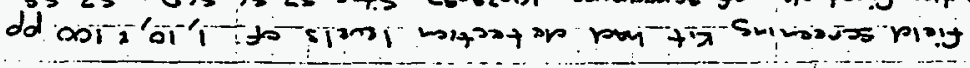


PROJECT 307-K RCRA ChArActorization

Notebook No. WM-3ML-HT

continued From Page -1.2

Procrelunes used in samplins:

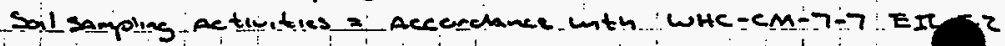

$$
\text { Revis, } 1
$$

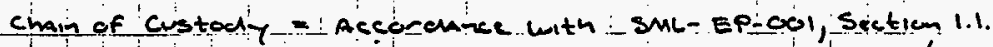
"chain of Custodyl. Sample Amaly sisireacest' Revo, eng l.

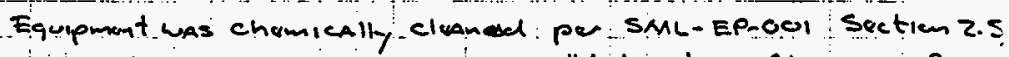
II Laborator 7 Cleming of Sampling Equpment" Rew 0 .

Sample Analysis:

- All Samples sebmitter to W/SCF for Amaylsis consistacl af. 25-20mi peily bottles far Activity Scan.

- All Samples submittral to Leekhied Enurounmental censisted of $25-20 \mathrm{ml}$ poly bottles fou. Acticity Sean $2 x_{2}=20 \mathrm{ml}$ pery butties for. Torbl Uranium

19 - $125 \mathrm{ml}$ Anber ghass widemaths fer Sami-VOA

4-125ml widemeatm poly bortiks fer ic Anions

$22-125 \mathrm{ml}$ widemeuth pory bottles for 1 Co Metais

3.- $500 \mathrm{ml}$ ludedematn port bottirs for ICP Metals

- All Sa-ples sebmitted to Paragen Analytics Ine work dome mdor JoAn K BAatr, Dupt of Ecolosp instrieticuns.

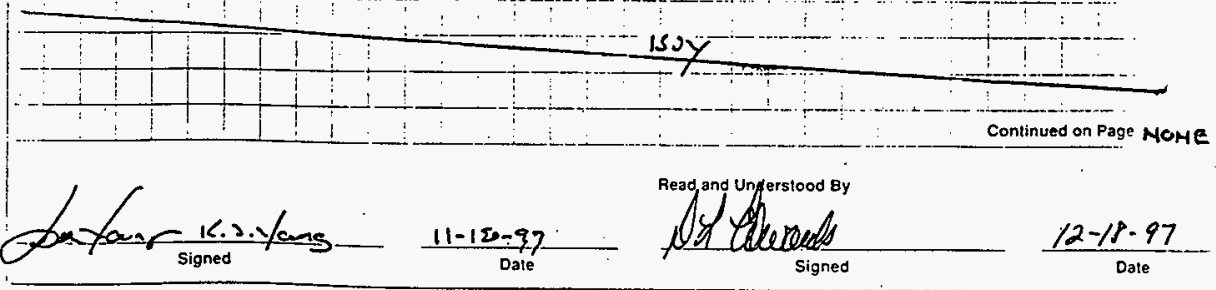


HNF-2959

1

2

ECOLOGY SPLIT SAMPLE DATA

APPENDIX B

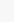


HNF-2959

1

2

3

4

5

6

This page intentionally left blank. 


\section{Paragon Analytics, Incorporated}

\section{Sample Number(s) Cross-Reference Table}

\section{Paragon OrderNum: 9711092 \\ Client Name: Washington State Dept. of Ecology \\ Client Project Name: \\ Client Project Number: 303-K Closure \\ Client PO Number:}

\begin{tabular}{|c|c|c|c|c|c|}
\hline $\begin{array}{c}\text { Client } \\
\text { Sample }\end{array}$ & $\begin{array}{c}\text { Lab Sample } \\
\text { Number }\end{array}$ & COC Number & Matrix & $\begin{array}{c}\text { Date } \\
\text { Collected }\end{array}$ & $\begin{array}{c}\text { Time } \\
\text { Collected }\end{array}$ \\
\hline S1 & $9711092-1$ & & Soil & $10 / 29 / 97$ & 13:05 \\
\hline$\$ 2$ & $9711092-2$ & & Soil & $10 / 29 / 97$ & $11: 37$ \\
\hline S3 & $9711092-3$ & & Soil & $10 / 29 / 97$ & $12: 15$ \\
\hline S5 & $9711092-4$ & & Soil & 10/30/97 & $10: 25$ \\
\hline S6 & $9711092-5$ & & Soil & $10 / 29 / 97$ & $11: 25$ \\
\hline 57 & $9711092-6$ & & Soil & $10 / 29 / 97$ & $11: 55$ \\
\hline 58 & $9711092-7$ & & Soil & $10 / 30 / 97$ & $11: 07$ \\
\hline 59 & $9711092-8$ & & Soil & $10 / 29 / 97$ & $12: 10$ \\
\hline S10-1 (upper) & $9711092-9$ & & Soil & $10 / 29 / 97$ & $12: 34$ \\
\hline S10-2 (lower) & $9711092-10$ & & Soil & $10 / 30 / 97$ & $10: 22$ \\
\hline S11-1 (upper) & $9711092-11$ & & Soil & $10 / 30 / 97$ & $11: 20$ \\
\hline S11-2 (lower) & $9711092-12$ & & Soil & $10 / 30 / 97$ & $13: 10$ \\
\hline S12-1 (upper) & $9711092-13$ & & Soil & $10 / 30 / 97$ & 13:10 \\
\hline S12-2 (lower) & $9711092-14$ & & Soil & $10 / 30 / 97$ & $13: 20$ \\
\hline C-1 (near drain) & $9711092-15$ & & Solid & $10 / 30 / 97$ & $14: 50$ \\
\hline $\mathrm{C}-2$ (near door) & $9711092-16$ & & Solid & 10/30/97 & $14: 40$ \\
\hline $\mathrm{C}-3$ (vent) & $9711092-17$ & & Solid & $10 / 30 / 97$ & $14: 30$ \\
\hline S4 & $9711092-18$ & & Soil & $10 / 29 / 97$ & $12: 36$ \\
\hline
\end{tabular}




\section{TOTAL URANIUM ANALYSIS RESULTS SUMALARY}

By Laser-Induced Kinetịc Phosphorimetry

Lab Name: Paragon Analytics, Inc.

Date Collected: $10 / 29 / 97$

Client Name: Washington State Dept. of Ecol Date Analyzed : 11/19/97

Client Project ID: Storage Facility

Lab Sample ID Series: 97-11-092

Sample Matrix : Soil

\begin{tabular}{|c|c|c|c|c|c|}
\hline Client Sample ID & $\begin{array}{c}\text { Lab } \\
\text { Sample ID }\end{array}$ & $\begin{array}{r}\text { Total } \\
\text { lug }\end{array}$ & $\begin{array}{l}\text { Uranium } \\
(\mathrm{g})\end{array}$ & $\begin{array}{c}\text { Reporting } \\
\text { Limit }\end{array}$ & Flag \\
\hline $\begin{array}{l}\text { S1 } \\
\text { S2 } \\
\text { S3 } \\
\text { S5 } \\
\text { S6 } \\
\text { S7 } \\
\text { S8 } \\
\text { S9 } \\
\text { S10-1 (upper) } \\
\text { Blank } \\
\text { Duplicate }\end{array}$ & $\begin{array}{l}11-092-01 \\
11-092-02 \\
11-092-03 \\
11-092-04 \\
11-092-05 \\
11-092-06 \\
11-092-07 \\
11-092-08 \\
11-092-09 \\
11-092-B 1 \\
11-092-01\end{array}$ & $\begin{array}{l}1.29 \\
17.3 \\
13.8 \\
68.3 \\
49.3 \\
143 \\
10.8 \\
28.7 \\
23.3 \\
0.15 \\
1.30\end{array}$ & $\begin{array}{lr} \pm & 0.18 \\
\pm & 2.4 \\
\pm & 1.9 \\
\pm & 9.4 \\
\pm & 6.8 \\
\pm & 20 \\
\pm & 1.5 \\
\pm & 4.0 \\
\pm & 3.2 \\
\pm & 0.02 \\
\pm & 0.18\end{array}$ & $\begin{array}{l}0.05 \\
0.10 \\
0.10 \\
0.10 \\
0.10 \\
0.10 \\
0.10 \\
0.10 \\
0.10 \\
0.05 \\
0.05\end{array}$ & \\
\hline
\end{tabular}

Reported Uncertainties are the Estimated Total Propagated Uncertainties $(2 \sigma)$.

See PAI SOP 743FC for details of TPU determinations.

FLAGS = J - 'Estimated Value' - result between Method Detection Limit and Reporting Limit.

U - 'Not Detected' - result less than Method Detection Limit.

Remarks :

Sample 97-11-092-D1 is a duplicate of 97-11-092-01. 
TOTAL URANIUM ANALYSIS RESULTS SUMMARY

By Laser-Induced Kinetic Phosphorimetry

Lab Name: Paragon Analytics, Inc.

Date Collected: $10 / 30 / 97$

Client Name: Washington State Dept. of Ecol Date Analyzed : 11/19/97

Client Project ID: Storage Facility

Lab Sample ID Series: 97-11-092

Sample Matrix : Soil

\begin{tabular}{|c|c|c|c|c|c|}
\hline Client Sample ID & $\begin{array}{l}\text { Lab } \\
\text { Sample ID }\end{array}$ & $\begin{array}{l}\text { Total } \\
\text { (ug/ }\end{array}$ & anium & $\begin{array}{c}\text { Reporting } \\
\text { Limit }\end{array}$ & Flag \\
\hline $\begin{array}{l}\text { S10-2 (lower) } \\
\text { SI1-1 (upper) } \\
\text { SI1-2 (Iower) } \\
\text { SI2-1 (upper) } \\
\text { S12-2 (lower) } \\
\text { C-1 (near drain) } \\
\text { C-2 (near door) } \\
\text { C-3 (vent) } \\
\text { S4 } \\
\text { Duplicate }\end{array}$ & $\begin{array}{l}11-092-10 \\
11-092-11 \\
11-092-12 \\
11-092-13 \\
11-092-14 \\
11-092-15 \\
11-092-16 \\
11-092-17 \\
11-092-18 \\
11-092-D 2\end{array}$ & $\begin{array}{r}7.8 \\
66.2 \\
29.9 \\
29.7 \\
16.6 \\
3071 \\
915 \\
3.67 \\
517 \\
7.9\end{array}$ & $\begin{array}{r}1.1 \\
9.1 \\
4.2 \\
4.1 \\
2.3 \\
420 \\
130 \\
0.50 \\
71 \\
1.1\end{array}$ & $\begin{array}{l}0.09 \\
0.23 \\
0.10 \\
0.09 \\
0.10 \\
0.97 \\
0.50 \\
0.10 \\
0.10 \\
0.10\end{array}$ & \\
\hline
\end{tabular}

Reported Uncertainties are the Estimated Total Propagated Uncertainties $(2 \sigma)$.

See PAI SOP 743FC for details of TPU determinations.

FLAGS = J - 'Estimated Value' - result between Method Detection Limit and Reporting Limit.

U - 'Not Detected' - result less than Method Detection Limit.

Remarks :

Sample 97-11-092-D2 is a duplicate of 97-11-092-10. 
1

\section{INORGANIC ANALYSES DATA SHEET}

Lab Name: PARAGON_ANALYTICS contract: SAS NO.:
Case No.:

Lab code: NA
EPA SAMPLE NO. s3
Matrix (soil/water): SoIL_

Level (low/med): LOW

solids:
$-90.9$
Lab Sampie ID: S9711092-3

Date Received: 11/07/97

Concentration Units (ug/L or mg/kg dry weight): MG/KG

\begin{tabular}{|l|}
\hline CAS NO. \\
\hline $7429-90-5$ \\
$7440-36-0$ \\
$7440-38-2$ \\
$7440-39-3$ \\
$7440-41-7$ \\
$7440-43-9$ \\
$7440-70-2$ \\
$7440-47-3$ \\
$7440-48-4$ \\
$7440-50-8$ \\
$7439-89-6$ \\
$7439-92-1$ \\
$7439-95-4$ \\
$7439-96-5$ \\
$7439-9.7-6$ \\
$7440-02-0$ \\
$7440-09-7$ \\
$7782-49-2$ \\
$7440-22-4$ \\
$7440-23-5$ \\
$7440-28-0$ \\
$7440-62-2$ \\
$7440-66-6$ \\
7 \\
\hline
\end{tabular}

Color Before: BROWN

Color After: TAN

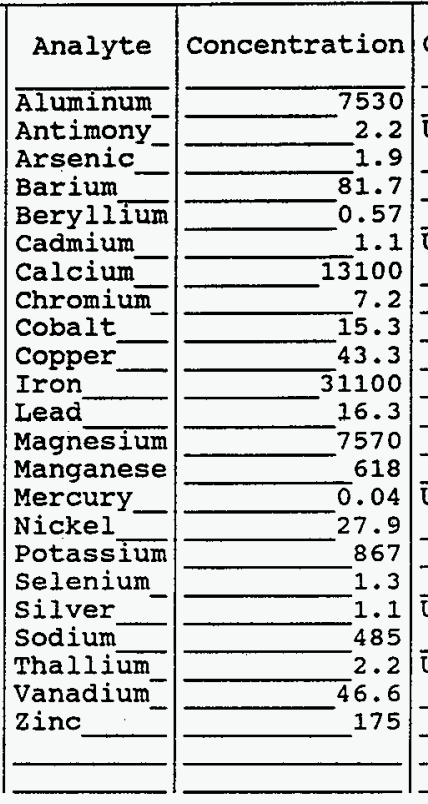

clarity Before: N/A

clarity After: CLEAR

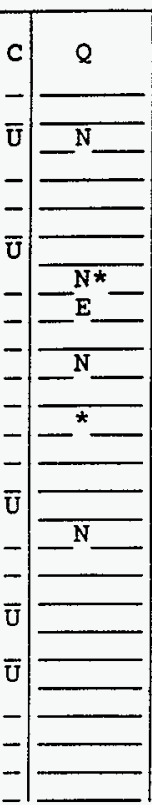

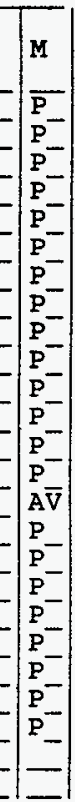

Texture: MEDIUM

Artifacts :

comments: 
1 INORGANIC ANALYSES DATA SHEET

Lab Name: PARAGON_ANAIYTICS Contract:

Iab code: NA

Case No.:

SAS NO.:
EPA SAMPLE NO.

S5
Matrix (soil/water): SOIL_

Level (low/med): IOW
Lab Sample ID: $\$ 9711092-4$

Date Received: 11/07/97

Solids: $-91.0$

Concentration Units (ug/L or $\mathrm{mg} / \mathrm{kg}$ dry weight): MG/KG

\begin{tabular}{|l|}
\hline CAS No. \\
\hline $7429-90-5$ \\
$7440-36-0$ \\
$7440-38-2$ \\
$7440-39-3$ \\
$7440-41-7$ \\
$7440-43-9$ \\
$7440-70-2$ \\
$7440-47-3$ \\
$7440-48-4$ \\
$7440-50-8$ \\
$7439-89-6$ \\
$7439-92-1$ \\
$7439-95-4$ \\
$7439-96-5$ \\
$7439-97-6$ \\
$7440-02-0$ \\
$7440-09-7$ \\
$7782-49-2$ \\
$7440-22-4$ \\
$7440-23-5$ \\
$7440-28-0$ \\
$7440-62-2$ \\
$7440-66-6$ \\
7 \\
\hline
\end{tabular}

Color Before: BROWN

Color After: TAN

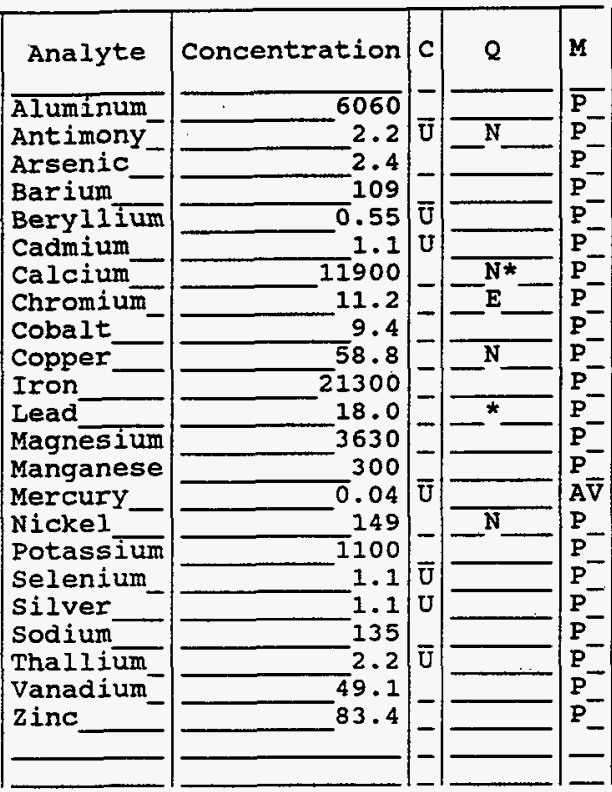

Clarity Before: N/A

Texture: MEDIUM Clarity After: CLEAR_

Artifacts:

Comments : 
1

INORGANIC ANALYSES DATA SHEET

Lab Name: PARAGON_ANALYTICS contract:

Case No.: SAS NO.:
EPA SAMPLE NO.

59

SDG NO.: RCRA
Lab Code: NA

Matrix (soil/water): SoII_

Level (low/med):

LOW

$-94 \cdot 8$

Solids:
Lab Sample ID: S9711092-8

Date Received: 11/07/97

Concentration Units (ug/L or $\mathrm{mg} / \mathrm{kg}$ dry weight): MG/KG

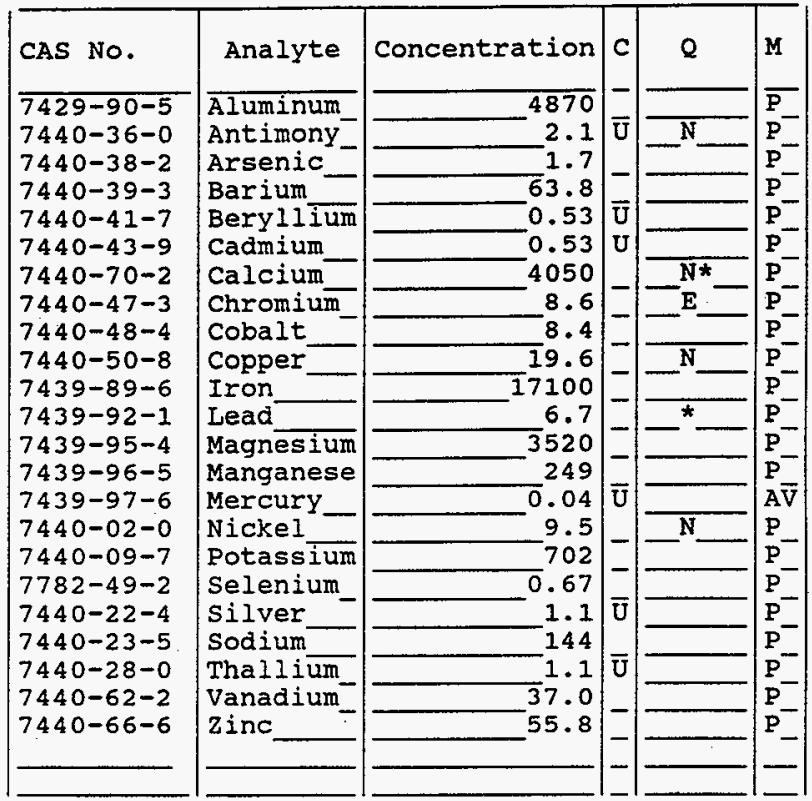

Color Before: BROWN

Color After: TAN
Clarity Before: $\mathrm{N} / \mathrm{A}$

Clarity After: CLEAR
Texture: MEDIUM

Artifacts:

Comments: 
1

INORGANIC ANALYSES DATA SHEET

Lab Name: PARAGON_ANALYTICS

Contract:

Case No.:

Lab Code: NA

OII

SAS NO.:

Lab Sample ID: S9711092-9

Level (low/med): Low

Date Received: 11/07/97

solias:

$-95.1$

Concentration Units (ug/I or $\mathrm{mg} / \mathrm{kg}$ dry weight) : MG/KG

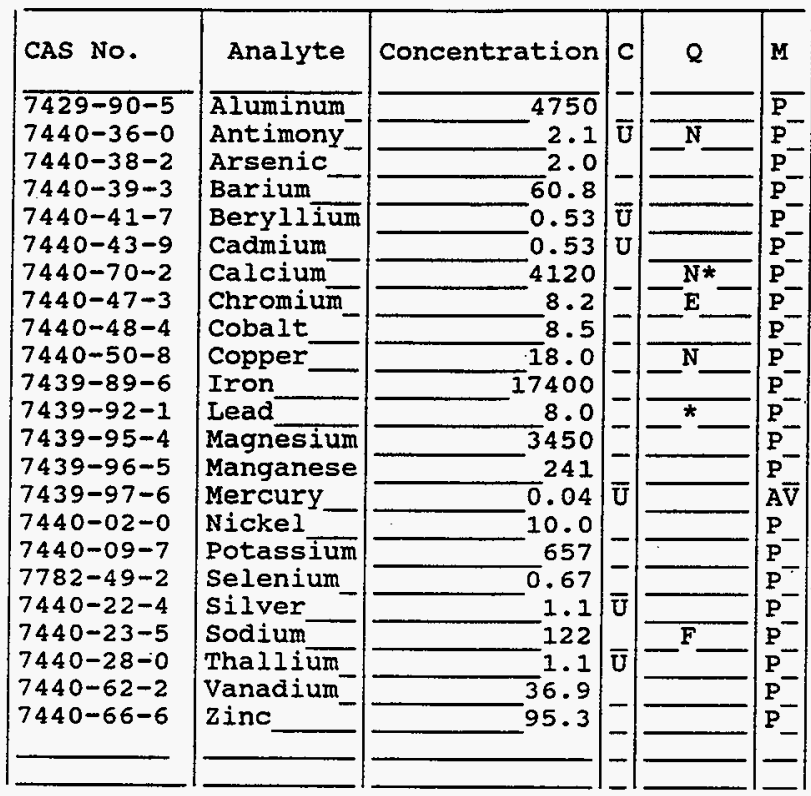

Color Before: BROWN

Clarity Before: N/A

Texture: MEDIUM

Color After: TAN

Clarity After: CLEAR

Artifacts:

Comments:

FULL_CLIENT_SAMPLE_ID_IS_S10-1_(UPPER) . 
1

INORGANIC ANALYSES DATA SHEET
EPA SAMPLE NO.

$510-2$
Lab Name: PARAGON_ANALYTICS

Lab code: NA

Case No.:

Matrix (soil/water): soII_

Level (low/med): LOW

Contract:

SAS NO.:

Lab Sample ID: S9711092-10

Date Received: 11/07/97

Solids:

$$
-92 \cdot 2
$$

Concentration Units (ug/L or $\mathrm{mg} / \mathrm{kg}$ dry weight): MG/KG

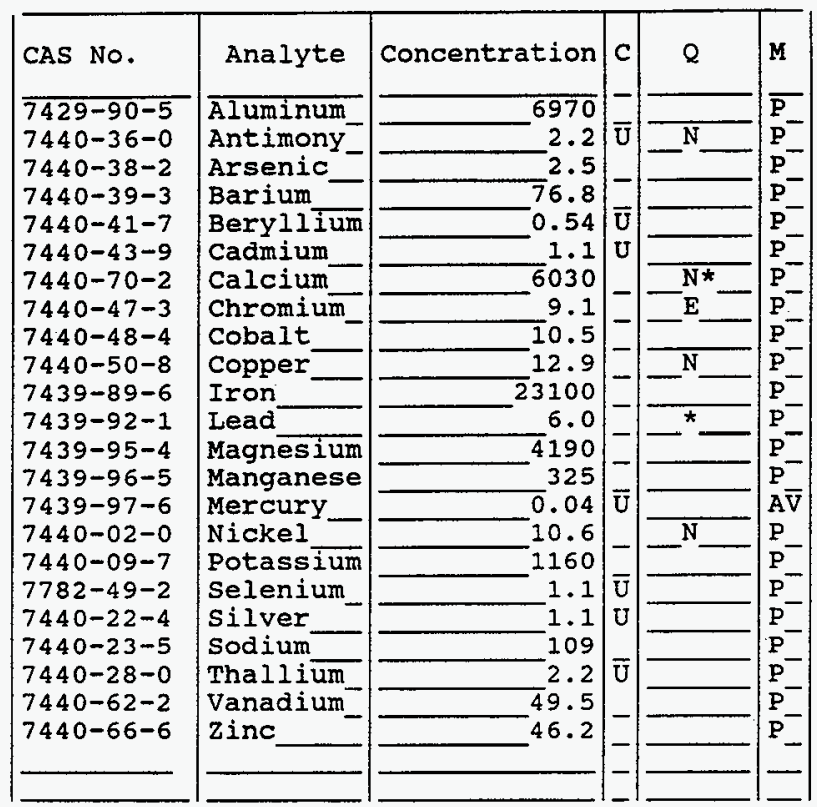

Color Before: BROWN

Color After: TAN
Clarity Before: N/A

clarity After: CLEAR
Texture: MEDIUM Artifacts :

Comments:

FULI_CLIENT_SAMPLE_ID_IS_S10-2_(LOWER). 


\section{U.S. EPA - CLP}

1

INORGANIC ANAEYSES DATA SHEET

Lab Name: PARAGON_ANAIYTICS

Contract:

SAS NO.:
EPA SAMPLE No.

$$
c-1
$$

SDG NO.: RCRA
Lab code: NA

Case No.:

Matrix (soil/water): soIL_

Level (low/med): Low

\% Solias:

-85.0
Concentration Units (ug/L or $\mathrm{mg} / \mathrm{kg}$ dry weight): MG/KG

Lab Sample ID: S9711092-15

Date Received: 11/07/97

\begin{tabular}{l}
\hline CAS NO. \\
$7429-90-5$ \\
$7440-36-0$ \\
$7440-38-2$ \\
$7440-39-3$ \\
$7440-41-7$ \\
$7440-43-9$ \\
$7440-70-2$ \\
$7440-47-3$ \\
$7440-48-4$ \\
$7440-50-8$ \\
$7439-89-6$ \\
$7439-92-1$ \\
$7439-95-4$ \\
$7439-96-5$ \\
$7439-97-6$ \\
$7440-02-0$ \\
$7440-09-7$ \\
$7782-49-2$ \\
$7440-22-4$ \\
$7440-23-5$ \\
$7440-28-0$ \\
$7440-62-2$ \\
$7440-66-6$ \\
\hline \\
\hline
\end{tabular}

Color Before: BROWN

Color After: TAN

\begin{tabular}{l} 
Analyte \\
\hline Aluminum \\
Antimony_- \\
Arsenic_- \\
Barium \\
Beryli ium \\
Cadmium \\
Calcium \\
Chromium \\
Cobalt \\
Copper_- \\
Iron \\
Lead \\
Magnesium \\
Manganese \\
Mercury \\
Nickel \\
Potassium \\
Selenium \\
Silver \\
Sodium \\
Thallium_- \\
Vanadium_- \\
Zinc \\
\hline \\
\hline
\end{tabular}

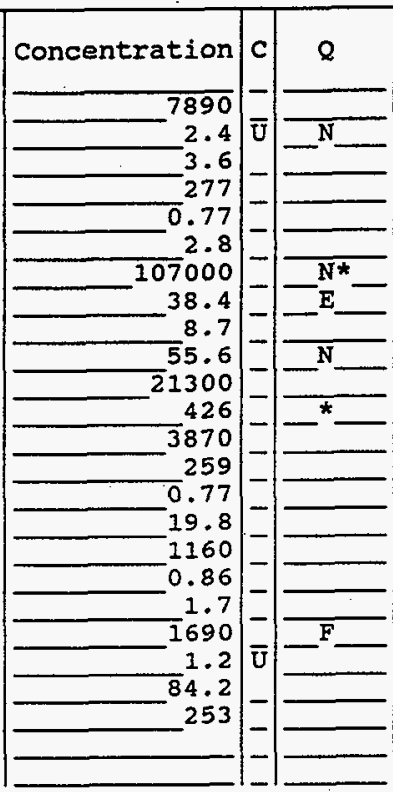

Clarity Before: N/A

Clarity After: CIEAR

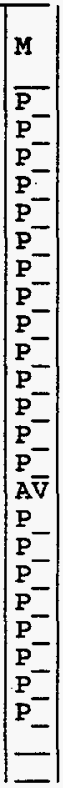

Texture:

MEDIUM

Artifacts :

\section{Comments:}

FULL_CLIENT_SAMPLE_ID_IS_C-1_(NEAR_DRAIN) . 
1

INORGANIC ANALYSES DATA SHEET
Lab Name: PARAGON_ANALYTICS contract:

Lab Code: NA

Case No.: SAS NO.:
EPA SAMPLE NO.

54

SDG NO.: RCRA
Matrix (soil/water): sorL_

Level (low/med): Low

solids: $-96.1$
Lab Sample ID: S9711092-18

Date Received: 11/07/97

Concentration Units (ug/L or $\mathrm{mg} / \mathrm{kg}$ dry weight): MG/KG

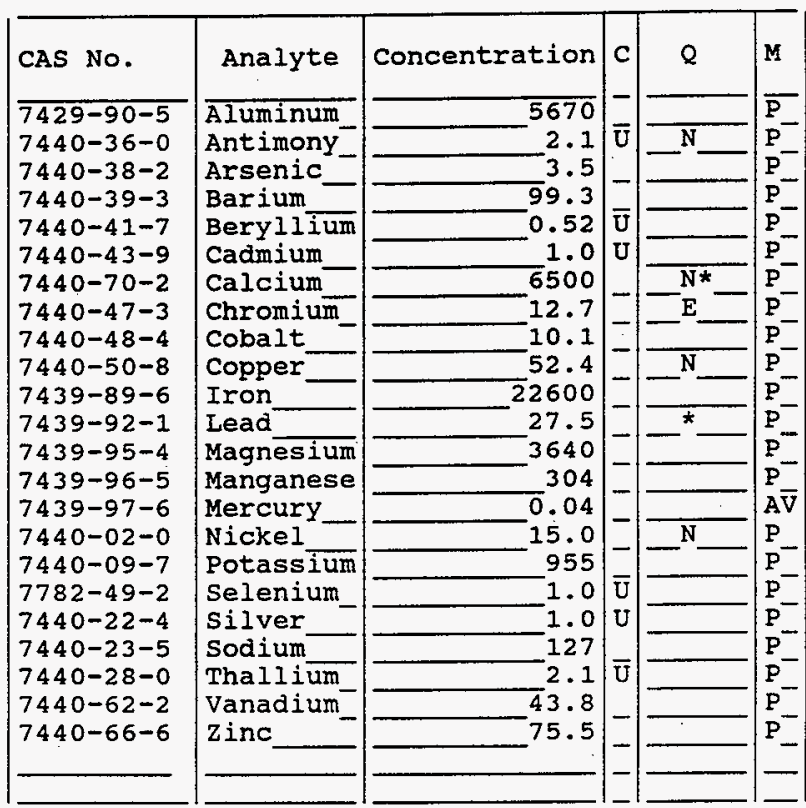

Color Before: BROWN

Clarity Before: N/A

Clarity After: CLEAR

Color Aftex: TAN

-

Texture: MEDIUM

Artifacts:

Comments: 


\section{AROCLORS}

Method 8081

Lab Name: Paragon Analytics, Inc.

Client Name: Washington State Department of Ecology

Sample ID

Client Project ID: RCRA Closue of 303-K Storage Facility

Date Collected: 10/29/97

Lab Sample ID: 9711092-1

Date Extracted: 11/12/97

Date Analyzed: 11/13/97

Sample Matrix: Soil

Cleanup: Sulfuric Acid

Sample Weight: $30 \mathrm{~g}$

\% Moisture: $6.2 \%$

Final Volume: $10 \mathrm{~mL}$

Results based on dry weight

Dilution Factor: 1

\begin{tabular}{|l|c|c|}
\hline Analyte & Conc (ug/kg) & $\begin{array}{c}\text { Reporting } \\
\text { Limit (ug/kg) }\end{array}$ \\
\hline \hline Arocior 1016 & ND & 36 \\
\hline Aroclor 1221 & ND & 71 \\
\hline Aroclor 1232 & ND & 36 \\
\hline Aroclor 1242 & ND & 36 \\
\hline Arocior 1248 & ND & 36 \\
\hline Aroclor 1254 & ND & 36 \\
\hline Aroclor 1260 & ND & 36 \\
\hline
\end{tabular}

SURROGATE RECOVERY

\begin{tabular}{|l|c|c|}
\hline Analyte & \% Recovery & \% Rec Limits \\
\hline \hline & & \\
2,4,5,6-Tetrachloro-m-xylene & 86 & $47-137$ \\
Decachlorobiphenyl & 94 & $34-129$ \\
\hline
\end{tabular}

$\mathrm{ND}=$ Not Detected at or above client requested reporting limit. 


\section{AROCLORS}

\section{Method 8081}

Lab Name: Paragon Analytics, Inc.

Client Name: Washington State Department of Ecology

Sample ID

Client Project ID: RCRA Closue of 303-K Storage Facility

Date Collected: 10/29/97

Lab Sample ID: 9711092-2

Date Extracted: 11/12/97

Sample Matrix: Soil

Cleanup: Sulfuric Acid

Date Analyzed: 11/14/97

\% Moisture: $4.3 \%$

Sample Weight: $30 \mathrm{~g}$

Results based on dry weight

Final Volume: $10 \mathrm{~mL}$

Dilution Factor: 5

\begin{tabular}{|l|c|c|}
\hline Analyte & Conc (ug/kg) & $\begin{array}{c}\text { Reporting } \\
\text { Limit (ug/kg) }\end{array}$ \\
\hline \hline Aroclor 1016 & ND & 170 \\
\hline Aroclor 1221 & ND & 350 \\
\hline Aroclor 1232 & ND & 170 \\
\hline Aroclor 1242 & ND & 170 \\
\hline Aroclor 1248 & ND & 170 \\
\hline Aroclor 1254 & 570 & 170 \\
\hline Aroclor 1260 & ND & 170 \\
\hline
\end{tabular}

SURROGATE RECOVERY

\begin{tabular}{|l|c|c|}
\hline Analyte & \% Recovery & \% Rec Limits \\
\hline \hline 2,4,5,6-Tetrachloro-m-xylene & 79 & $47-137$ \\
Decachlorobiphenyl & 81 & $34-129$ \\
\hline
\end{tabular}

$\mathrm{ND}=$ Not Detected at or above client requested reporting limit. 


\section{AROCLORS}

\section{Method 8081}

Lab Name: Paragon Analytics. Inc.

Client Name: Washington State Department of Ecology

Sample ID

Client Project ID: RCRA Closue of 303-K Storage Facility

S3

Date Collected: 10/29/97

Lab Sample ID: 9711092-3

Date Extracted: 11/12/97

Date Analyzed: 11/14/97

Sample Matrix: Soil

Cleanup: Sulfuric Acid

Sample Weight: $30 \mathrm{~g}$

\% Moisture: $9.1 \%$

Results based on dry weight

Final Volume: $10 \mathrm{~mL}$

Dilution Factor: 2

\begin{tabular}{|l|c|c|}
\hline Analyte & Conc (ug/kg) & $\begin{array}{c}\text { Reporting } \\
\text { Limit (ug/kg) }\end{array}$ \\
\hline \hline Aroclor 1016 & ND & 73 \\
\hline Aroclor 1221 & ND & 150 \\
\hline Aroclor 1232 & ND & 73 \\
\hline Aroclor 1242 & ND & 73 \\
\hline Aroclor 1248 & ND & 73 \\
\hline Aroclor 1254 & 250 & 73 \\
\hline Aroclor 1260 & ND & 73 \\
\hline
\end{tabular}

SURROGATE RECOVERY

\begin{tabular}{|l|c|c|}
\hline Analyte & \% Recovery & \% Rec Limits \\
\hline 2,4,5,6-Tetrachloro-m-xylene & 88 & $47-137$ \\
Decachlorobiphenyl & 88 & $34-129$ \\
\hline
\end{tabular}

$\mathrm{ND}=$ Not Detected at or above client requested reporting limit. 


\section{AROCLORS}

\section{Method 8081}

Lab Name: Paragon Analytics, Inc.

Client Name: Washington State Department of Ecology

Sample ID

Client Project ID: RCRA Closue of 303-K Storage Facility

Date Collected: 10/30/97

Lab Sample ID: $9711092-4$

Date Extracted: 11/12/97

Date Analyzed: $11 / 13 / 97$

Sample Matrix: Soil

Cleanup: Sulfuric Acid

Sample Weight: $30 \mathrm{~g}$

$\%$ Moisture: $9 \%$

Final Volume: $10 \mathrm{~mL}$

Results based on dry weight

Dilution Factor: 1

\begin{tabular}{|l|c|c|}
\hline Analyte & Conc $(\mathrm{ug} / \mathrm{kg})$ & $\begin{array}{c}\text { Reporting } \\
\text { Limit }(\mathrm{ug} / \mathrm{kg})\end{array}$ \\
\hline \hline Aroclor 1016 & ND & 37 \\
\hline Aroclor 1221 & ND & 73 \\
\hline Aroclor 1232 & ND & 37 \\
\hline Arocior 1242 & ND & 37 \\
\hline Aroclor 1248 & ND & 37 \\
\hline Aroclor 1254 & 160 & 37 \\
\hline Aroclor 1260 & 85 & 37 \\
\hline
\end{tabular}

\section{SURROGATE RECOVERY}

\begin{tabular}{|l|c|c|}
\hline Analyte & \% Recovery & \% Rec Limits \\
\hline & & \\
2,4,5,6-Tetrachloro-m-xylene & 75 & $47-137$ \\
Decachlorobiphenyl & 93 & $34-129$ \\
\hline
\end{tabular}

$\mathrm{ND}=$ Not Detected at or above client requested reporting limit. 


\section{AROCLORS}

\section{Method 8081}

Lab Name: Paragon Analytics, Inc.

Client Name: Washington State Department of Ecology

Sample ID

Client Project ID: RCRA Closue of 303-K Storage Facility

Date Collected: 10/29/97

Lab Sample ID: $9711092-5$

Date Extracted: 11/12/97

Date Analyzed: 11/13/97

Sample Matrix: Soil

Cleanup: Sulfuric Acid

Sample Weight: $30 \mathrm{~g}$

\% Moisture: $6.9 \%$

Results based on dry weight

Final Volume: $10 \mathrm{~mL}$

Dilution Factor: 1

\begin{tabular}{|l|c|c|}
\hline Analyte & Conc (ug/kg) & $\begin{array}{c}\text { Reporting } \\
\text { Limit (ug/kg) }\end{array}$ \\
\hline \hline Aroclor 1016 & ND & 36 \\
\hline Aroclor 1221 & ND & 72 \\
\hline Aroclor 1232 & ND & 36 \\
\hline Aroclor 1242 & ND & 36 \\
\hline Aroclor 1248 & ND & 36 \\
\hline Aroclor 1254 & ND & 36 \\
\hline Arocior 1260 & ND & 36 \\
\hline
\end{tabular}

SURROGATE RECOVERY

\begin{tabular}{|l|c|c|}
\hline Analyte & \% Recovery & \% Rec Limits \\
\hline \hline & & \\
2,4,5,6-Tetrachloro-m-xylene & 96 & $47-137$ \\
Decachlorobiphenyl & 102 & $34-129$ \\
\hline
\end{tabular}

$\mathrm{ND}=$ Not Detected at or above client requested reporting limit. 


\section{AROCLORS}

\section{Method 8081}

Sample ID

Lab Name: Paragon Analytics, Inc.

Client Name: Washington State Department of Ecology

S7

Client Project ID: RCRA Closue of 303-K Storage Facility

Date Collected: 10/29/97

Lab Sample ID: 9711092-6

Date Extracted: $11 / 12 / 97$

Sample Matrix: Soil

Cleanup: Sulfuric Acid

Date Analyzed: 11/13/97

\% Moisture: $6.4 \%$

Sample Weight: $30 \mathrm{~g}$

Resuits based on dry weight

Final Volume: $10 \mathrm{~mL}$

Dilution Factor: 1

\begin{tabular}{|l|c|c|}
\hline Analyte & Conc (ug/kg) & $\begin{array}{c}\text { Reporting } \\
\text { Limit (ug/kg) }\end{array}$ \\
\hline \hline Arocior 1016 & ND & 36 \\
\hline Aroclor 1221 & ND & 71 \\
\hline Aroclor 1232 & ND & 36 \\
\hline Arocior 1242 & ND & 36 \\
\hline Aroclor 1248 & ND & 36 \\
\hline Arocior 1254 & 100 & 36 \\
\hline Aroclor 1260 & 76 & 36 \\
\hline
\end{tabular}

SURROGATE RECOVERY

\begin{tabular}{|l|c|c|}
\hline Analyte & \% Recovery & \% Rec Limits \\
\hline 2,4,5,6-Tetrachloro-m-xylene & 92 & $47-137$ \\
Decachlorobiphenyl & 97 & $34-129$ \\
\hline
\end{tabular}

$\mathrm{ND}=$ Not Detected at or above client requested reporting limit. 


\section{AROCLORS}

\section{Method 8081}

Lab Name: Paragon Analytics, Inc.

Client Name: Washington State Department of Ecology

Client Project ID: RCRA Closue of 303-K Storage Facility

Sample ID

Lab Sampie ID: 9711092-7

Date Collected: 10/30/97

Date Extracted: 11/12/97

Sample Matrix: Soil

Cleanup: Sulfuric Acid

Date Analyzed: 11/13/97

\% Moisture: $5.3 \%$

Results based on dry weight

Sample Weight: $30 \mathrm{~g}$ Final Volume: $10 \mathrm{~mL}$

Dilution Factor: 1

\begin{tabular}{|l|c|c|}
\hline Analyte & Conc (ug/kg) & $\begin{array}{c}\text { Reporting } \\
\text { Limit (ug/kg) }\end{array}$ \\
\hline \hline Aroclor 1016 & ND & 35 \\
\hline Aroclor 1221 & ND & 70 \\
\hline Aroclor 1232 & ND & 35 \\
\hline Aroclor 1242 & ND & 35 \\
\hline Aroclor 1248 & ND & 35 \\
\hline Aroclor 1254 & ND & 35 \\
\hline Aroclor 1260 & ND & 35 \\
\hline
\end{tabular}

\section{SURROGATE RECOVERY}

\begin{tabular}{|l|c|c|}
\hline Analyte & \% Recovery & \% Rec Limits \\
\hline \hline 2,4,5,6-Tetrachloro-m-xylene & 96 & $47-137$ \\
Decachlorobiphenyl & 96 & $34-129$ \\
\hline
\end{tabular}

ND $=$ Not Detected at or above client requested reporting limit. 


\section{AROCLORS}

\section{Method 8081}

Sample ID

Lab Name: Paragon Analytics, Inc.

Client Name: Washington State Deparment of Ecology

s9

Client Project ID: RCRA Closue of 303-K Storage Facility

Date Collected: 10/29/97

Lab Sample ID: $9711092-8$

Date Extracted: 11/12/97

Date Analyzed: 11/13/97

Sample Matrix: Soil

Cleanup: Sulfuric Acid

Sample Weight: $30 \mathrm{~g}$

$\%$ Moisture: $5.2 \%$

Results based on dry weight

Final Volume: $10 \mathrm{~mL}$

Dilution Factor: 1

\begin{tabular}{|l|c|c|}
\hline Analyte & Conc (ug/kg) & $\begin{array}{c}\text { Reporting } \\
\text { Limit (ug/kg) }\end{array}$ \\
\hline \hline Aroclor 1016 & ND & 35 \\
\hline Aroclor 1221 & ND & 70 \\
\hline Aroclor 1232 & ND & 35 \\
\hline Aroclor 1242 & ND & 35 \\
\hline Arocior 1248 & ND & 35 \\
\hline Aroclor 1254 & 81 & 35 \\
\hline Arocior 1260 & ND & 35 \\
\hline
\end{tabular}

SURROGATE RECOVERY

\begin{tabular}{|l|c|c|}
\hline Analyte & \% Recovery & \% Rec Limits \\
\hline \hline & 91 & $47-137$ \\
2,4,5,6-Tetrachloro-m-xylene & 89 & $34-129$ \\
\hline Decachlorobiphenyl & 91 & \\
\hline
\end{tabular}

ND $=$ Not Detected at or above client requested reporting limit. 


\section{AROCLORS}

Method 8081

Lab Name: Paragon Analytics, Inc.

Client Name: Washington State Department of Ecology

Sample ID

Client Project ID: RCRA Closue of 303-K Storage Facility

S10-1 (upper)

Date Collected: 10/29/97

Lab Sample ID: 9711092-9

Date Extracted: 11/12/97

Sample Matrix: Soil

Cleanup: Sulfuric Acid

Date Analyzed: 11/13/97

\% Moisture: $4.9 \%$

Sample Weight: $30 \mathrm{~g}$

Results based on dry weight

Final Volume: $10 \mathrm{mI}$

Dilution Factor: 1

\begin{tabular}{|l|c|c|}
\hline Analyte & Conc (ug/kg) & $\begin{array}{c}\text { Reporting } \\
\text { Limit (ug/kg) }\end{array}$ \\
\hline \hline Aroclor 1016 & ND & 35 \\
\hline Aroclor 1221 & ND & 70 \\
\hline Arocior 1232 & ND & 35 \\
\hline Aroclor 1242 & ND & 35 \\
\hline Aroclor 1248 & ND & 35 \\
\hline Aroclor 1254 & 79 & 35 \\
\hline Arocior 1260 & ND & 35 \\
\hline
\end{tabular}

SURROGATE RECOVERY

\begin{tabular}{|l|c|c|}
\hline Analyte & \%Recovery & \% Rec Limits \\
\hline \hline & 89 & $47-137$ \\
2,4,5,6-Tetrachloro-m-xylene & 87 & $34-129$ \\
\hline Decachlorobiphenyl & 89 & \\
\hline
\end{tabular}

$\mathrm{ND}=$ Not Detected at or above client requested reporting limit. 


\section{AROCLORS}

\section{Method 8081}

Lab Name: Paragon Analytics, Inc.

Client Name: Washington State Department of Ecology

Client Project ID: RCRA Closue of 303-K Storage Facility

Sample ID

S10-2 (lower)

Date Collected: 10/30/97

Lab Sample ID: 9711092-10

Date Extracted: 11/12/97

Date Analyzed: 11/14/97

Sample Matrix: Soil

Cleanup: Sulfuric Acid

Sample Weight: $30 \mathrm{~g}$

\% Moisture: $7.8 \%$

Final Volume: $10 \mathrm{~mL}$

Results based on dry weight

Dilution Factor: 1

\begin{tabular}{|l|c|c|}
\hline Analyte & Conc (ug/kg) & $\begin{array}{c}\text { Reporting } \\
\text { Limit (ug/kg) }\end{array}$ \\
\hline \hline Aroclor 1016 & ND & 36 \\
\hline Aroclor 1221 & ND & 72 \\
\hline Aroclor 1232 & ND & 36 \\
\hline Aroclor 1242 & ND & 36 \\
\hline Aroclor 1248 & ND & 36 \\
\hline Aroclor 1254 & ND & 36 \\
\hline Aroclor 1260 & ND & 36 \\
\hline
\end{tabular}

SURROGATE RECOVERY

\begin{tabular}{|l|c|c|}
\hline Analyte & \% Recovery & \% Rec Limits \\
\hline \hline & 93 & $47-137$ \\
$2,4,5,6-$ Tetrachloro-m-xylene & 93 & $34-129$ \\
Decachlorobiphenyl & 93 & \\
\hline
\end{tabular}

$\mathrm{ND}=$ Not Detected at or above client requested reporting limit. 


\section{AROCLORS}

\section{Method 8081}

Lab Name: Paragon Analytics, Inc.

Client Name: Washington State Department of Ecology

Client Project ID: RCRA Closue of 303-K Storage Facility

Sample ID

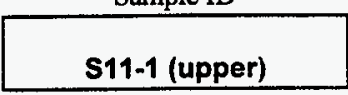

Date Collected: 10/30/97

Lab Sample ID: 9711092-11

Date Extracted: 11/12/97

Date Analyzed: 11/14/97

Sample Matrix: Soil

Cleanup: Sulfuric Acid

Sample Weight: $30 \mathrm{~g}$

$\%$ Moisture: $6.7 \%$

Results based on dry weight

Final Volume: $10 \mathrm{~mL}$

Dilution Factor: 5

\begin{tabular}{|l|c|c|}
\hline Analyte & Conc (ug/kg) & $\begin{array}{c}\text { Reporting } \\
\text { Limit (ug/kg) }\end{array}$ \\
\hline \hline Aroclor 1016 & ND & 180 \\
\hline Aroclor 1221 & ND & 360 \\
\hline Aroclor 1232 & ND & 180 \\
\hline Aroclor 1242 & ND & 180 \\
\hline Aroclor 1248 & ND & 180 \\
\hline Aroclor 1254 & 670 & 180 \\
\hline Aroclor 1260 & ND & 180 \\
\hline
\end{tabular}

\section{SURROGATE RECOVERY}

\begin{tabular}{|l|c|c|}
\hline Analyte & \% Recovery & \% Rec Limits \\
\hline \hline & 86 & $47-137$ \\
2,4,5,6-Tetrachloro-m-xylene & 91 & $34-129$ \\
\hline
\end{tabular}

$\mathrm{ND}=$ Not Detected at or above client requested reporting limit. 


\section{AROCLORS}

Method 8081

Lab.Name: Paragon Analytics, Inc.

Client Name: Washington State Department of Ecology

Client Project ID; RCRA Closue of 303-K Storage Facility

Sample ID

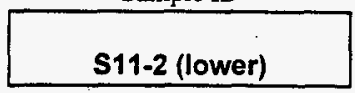

S11-2 (lower)

Date Collected: 10/30/97

Lab Sample ID: $9711092-12$

Date Extracted: 11/12/97

Date Analyzed: 11/14/97

Sample Matrix: Soil

Cleanup: Sulfuric Acid

Sample Weight: $30 \mathrm{~g}$

\% Moisture: $9.9 \%$

Final Volume: $10 \mathrm{~mL}$

Results based on dry weight

Dilution Factor: 1

\begin{tabular}{|l|c|c|}
\hline Analyte & Conc (ug/kg) & $\begin{array}{c}\text { Reporting } \\
\text { Limit (ug/kg) }\end{array}$ \\
\hline \hline Aroclor 1016 & ND & 37 \\
\hline Aroclor 1221 & ND & 74 \\
\hline Aroclor 1232 & ND & 37 \\
\hline Aroclor 1242 & ND & 37 \\
\hline Aroclor 1248 & ND & 37 \\
\hline Aroclor 1254 & 69 & 37 \\
\hline Aroclor 1260 & ND & 37 \\
\hline
\end{tabular}

SURROGATE RECOVERY

\begin{tabular}{|l|c|c|}
\hline Analyte & \% Recovery & $\%$ Rec Limits \\
\hline \hline 2,4,5,6-Tetrachloro-m-xylene & 93 & $47-137$ \\
Decachlorobiphenyl & 89 & $34-129$ \\
\hline
\end{tabular}

ND $=$ Not Detected at or above client requested reporting limit. 


\section{AROCLORS}

\section{Method 8081}

Sample ID

Lab Name: Paragon Analytics, Inc.

Client Name: Washington State Department of Ecology

S12-1 (upper)

Client Project ID: RCRA Closue of 303-K Storage Facility

Date Collected: 10/30/97

Lab Sample ID: 9711092-13

Date Extracted: 11/12/97

Date Analyzed: 11/14/97

Sample Matrix: Soil

Cleanup: Sulfuric Acid

Sample Weight: $30 \mathrm{~g}$

\% Moisture: $6.8 \%$

Final Volume: $10 \mathrm{~mL}$

Results based on dry weight

Dilution Factor: 1

\begin{tabular}{|l|c|c|}
\hline Analyte & Conc (ug/kg) & $\begin{array}{c}\text { Reporting } \\
\text { Limit (ug/kg) }\end{array}$ \\
\hline \hline Aroclor 1016 & ND & 36 \\
\hline Aroclor 1221 & ND & 72 \\
\hline Aroclor 1232 & ND & 36 \\
\hline Aroclor 1242 & ND & 36 \\
\hline Aroclor 1248 & ND & 36 \\
\hline Aroclor 1254 & 190 & 36 \\
\hline Aroclor 1260 & 39 & 36 \\
\hline
\end{tabular}

\section{SURROGATE RECOVERY}

\begin{tabular}{|l|c|c|}
\hline Analyte & \% Recovery & \% Rec Limits \\
\hline \hline & & \\
2,4,5,6-Tetrachloro-m-xylene & 91 & $47-137$ \\
Decachlorobiphenyl & 91 & $34-129$ \\
\hline
\end{tabular}

$\mathrm{ND}=$ Not Detected at or above client requested reporting limit. 


\section{AROCLORS}

\section{Method 8081}

Lab Name: Paragon Analytics, Inc.

Client Name: Washington State Department of Ecology

Client Project ID: RCRA Closue of 303-K Storage Facility

Sample ID

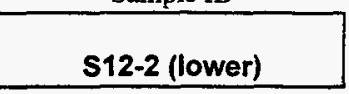

Date Collected: 10/30/97

Lab Sample ID: 9711092-14

Date Extracted: 11/12/97

Date Analyzed: 11/14/97

Sample Matrix: Soil

Cleanup: Sulfuric Acid

Sample Weight: $30 \mathrm{~g}$

\% Moisture: $6.4 \%$

Results based on dry weight

Final Volume: $10 \mathrm{~mL}$

Dilution Factor: 1

\begin{tabular}{|l|c|c|}
\hline Anaiyte & Conc (ug/kg) & $\begin{array}{c}\text { Reporting } \\
\text { Limit (ug/kg) }\end{array}$ \\
\hline Aroclor 1016 & ND & 36 \\
\hline Aroclor 1221 & ND & 71 \\
\hline Aroclor 1232 & ND & 36 \\
\hline Aroclor 1242 & ND & 36 \\
\hline Aroclor 1248 & ND & 36 \\
\hline Aroclor 1254 & ND & 36 \\
\hline Aroclor 1260 & ND & 36 \\
\hline
\end{tabular}

SURROGATE RECOVERY

\begin{tabular}{|l|c|c|}
\hline Analyte & \% Recovery & \% Rec Limits \\
\hline \hline & & \\
2,4,5,6-Tetrachioro-m-xylene & 97 & $47-137$ \\
Decachlorobiphenyl & 101 & $34-129$ \\
\hline
\end{tabular}

$\mathrm{ND}=$ Not Detected at or above client requested reporting limit. 


\section{AROCLORS}

\section{Method 8081}

Lab Name: Paragon Analytics, Inc.

Client Name: Washington State Department of Ecology

Sample ID

Client Project ID: RCRA Closue of 303-K Storage Facility

C-1 (near drain)

Date Collected: 10/30/97

Lab Sample ID: 9711 1092-15

Date Extracted: 11/12/97

Date Analyzed: 11/14/97

Sample Matrix: Soil

Cleanup: Sulfuric Acid

Sample Weight: $30 \mathrm{~g}$

$\%$ Moisture: $15 \%$

Final Volume: $10 \mathrm{~mL}$

Results based on dry weight

Dilution Factor: 10

\begin{tabular}{|l|c|c|}
\hline Analyte & Conc (ug/kg) & $\begin{array}{c}\text { Reporting } \\
\text { Limit (ug/kg) }\end{array}$ \\
\hline \hline Aroclor 1016 & ND & 390 \\
\hline Aroclor 1221 & ND & 780 \\
\hline Aroclor 1232 & ND & 390 \\
\hline Aroclor 1242 & ND & 390 \\
\hline Aroclor 1248 & ND & 390 \\
\hline Arocior 1254 & 1,200 & 390 \\
\hline Aroclor 1260 & ND & 390 \\
\hline
\end{tabular}

\section{SURROGATE RECOVERY}

\begin{tabular}{|l|c|c|}
\hline Analyte & \% Recovery & \% Rec Limits \\
\hline \hline & 76 & $47-137$ \\
2,4,5,6-Tetrachloro-m-xylene & 66 & $34-129$ \\
Decachlorobiphenyl & 76
\end{tabular}

ND $=$ Not Detected at or above client requested reporting limit. 


\section{AROCLORS}

\section{Method 8081}

Lab Name: Paragon Analytics, Inc.

Client Name: Washington State Department of Ecology

Sample ID

Client Project ID: RCRA Closue of 303-K Storage Facility

C-2 (near door)

Date Collected: $10 / 30 / 97$

Lab Sample ID: $9711092-16$

Date Extracted: 11/12/97

Date Analyzed: 11/14/97

Sample Matrix: Soil

Cleanup: Sulfuric Acid

Sample Weight: $30 \mathrm{~g}$

$\%$ Moisture: $6.8 \%$

Final Volume: $10 \mathrm{~mL}$

Results based on dry weight

Dilution Factor: 50

\begin{tabular}{|l|c|c|}
\hline Analyte & Conc (ug/kg) & $\begin{array}{c}\text { Reporting } \\
\text { Limit (ug/kg) }\end{array}$ \\
\hline \hline Arocior 1016 & $\mathrm{ND}$ & 1,800 \\
\hline Arocior 1221 & $\mathrm{ND}$ & 3,600 \\
\hline Aroclor 1232 & $\mathrm{ND}$ & 1,800 \\
\hline Aroclor 1242 & $\mathrm{ND}$ & 1,800 \\
\hline Aroclor 1248 & $\mathrm{ND}$ & 1,800 \\
\hline Aroclor 1254 & 4,700 & 1,800 \\
\hline Aroclor 1260 & $\mathrm{ND}$ & 1,800 \\
\hline
\end{tabular}

SURROGATE RECOVERY

\begin{tabular}{|l|c|c|}
\hline Analyte & \% Recovery & \% Rec Limits \\
\hline \hline 2,4,5,6-Tetrachloro-m-xylene & I & $47-137$ \\
Decachiorobiphenyl & I & $34-129$ \\
\hline
\end{tabular}

$\mathrm{ND}=$ Not Detected at or above client requested reporting limit.

I = Surrogate recovery not reported due to sample dilution. 


\section{AROCLORS}

\section{Method 8081}

Lab Name: Paragon Analytics, Inc.

Client Name: Washington State Department of Ecology

Client Project ID: RCRA Closue of 303-K Storage Facility

Date Collected: 10/30/97

Lab Sample ID: 9711092-17

Date Extracted: 11/12/97

Date Analyzed: 11/14/97.

Sample Matrix: Soil

Cleanup: Sulfuric Acid

Sample Weight: $30 \mathrm{~g}$

\% Moisture: $1.5 \%$

Final Volume: $10 \mathrm{~mL}$

Results based on dry weight

Dilution Factor: 10

\begin{tabular}{|l|c|c|}
\hline Analyte & Conc (ug/kg) & $\begin{array}{c}\text { Reporting } \\
\text { Limit (ug/kg) }\end{array}$ \\
\hline \hline Arocior 1016 & ND & 340 \\
\hline Aroclor 1221 & ND & 680 \\
\hline Aroclor 1232 & ND & 340 \\
\hline Aroclor 1242 & ND & 340 \\
\hline Arocior 1248 & ND & 340 \\
\hline Arocior 1254 & 650 & 340 \\
\hline Arocior 1260 & ND & 340 \\
\hline
\end{tabular}

SURROGATE RECOVERY

\begin{tabular}{|l|c|c|}
\hline Analyte & \% Recovery & \% Rec Limits \\
\hline \hline & & \\
2,4,5,6-Tetrachloro-m-xylene & 61 & $47-137$ \\
Decachlorobiphenyl & 42 & $34-129$ \\
\hline
\end{tabular}

$\mathrm{ND}=$ Not Detected at or above client requested reporting limit. 


\section{AROCLORS}

\section{Method 8081}

Lab Name: Paragon Analytics, Inc.

Client Name: Washington State Department of Ecology

Sample ID

Client Project ID: RCRA Closue of 303-K Storage Facility

Lab Sample ID: $9711092-18$

Date Collected: 10/29/97

Date Extracted: 11/12/97

Sample Matrix: Soil

Date Analyzed: 11/13/97

Cleanup: Sulfuric Acid

Sample Weight: $30 \mathrm{~g}$

\% Moisture: $3.9 \%$

Final Volume: $10 \mathrm{~mL}$

Results based on dry weight

Dilution Factor: 1

\begin{tabular}{|l|c|c|}
\hline Analyte & Conc (ug/kg) & $\begin{array}{c}\text { Reporting } \\
\text { Limit (ug/kg) }\end{array}$ \\
\hline \hline Arocior 1016 & ND & 35 \\
\hline Arocior 1221 & ND & 69 \\
\hline Aroclor 1232 & ND & 35 \\
\hline Aroclor 1242 & ND & 35 \\
\hline Aroclor 1248 & ND & 35 \\
\hline Aroclor 1254 & 160 & 35 \\
\hline Aroclor 1260 & 120 & 35 \\
\hline
\end{tabular}

\section{SURROGATE RECOVERY}

\begin{tabular}{|l|c|c|}
\hline Analyte & \% Recovery & \% Rec Limits \\
\hline \hline 2,4,5,6-Tetrachloro-m-xylene & 95 & $47-137$ \\
Decachlorobiphenyl & 101 & $34-129$ \\
\hline
\end{tabular}

$\mathrm{ND}=$ Not Detected at or above client requested reporting limit. 


\section{Semi-volatile Organics by GC/MS}

\section{Method SW8270}

Lab Name: Paragon Anabytics, Inc.

Work Order Number: 9711092

Client Name: Washington State Dept. of Ecol

ClientProject ID: RCRA Closure of 303-K >

Reported on: Tuesday, November 18, 1997

Field ID: $\$ 3$

Lab ID: $9711092-3$
Sample Matrix: solid

\% Moisture: 9.1

Cleanup Method: NONE

Report Basis: DRY WEIGHT
Date Collected: $29-0 \mathrm{ct}-97$

Date Extracted: 11-Nov-97

Date Analyzed: 14-Nov-97

Prep Batch: sv11092
Sample Aliquot:

Final Volume:

Dilution:

\begin{tabular}{|c|c|c|c|c|c|c|}
\hline CASNO & Target Analyte & Result & Units. & $\begin{array}{c}\text { Reporting } \\
\text { Limit }\end{array}$ & $\begin{array}{l}\text { Result } \\
\text { Qualifier }\end{array}$ & $\begin{array}{l}\text { Result } \\
\text { Footnote }\end{array}$ \\
\hline $110-86-1$ & PYRIDINE & 730 & $u g / k g$ & 730 & $u$ & \\
\hline 62-75-9 & N-NITROSODIMETHYLAMINE & 730 & $u g / \mathrm{kg}$ & 730 & $u$ & \\
\hline $62-53-3$ & ANILINE & 1800 & ug/kg & 1800 & $u$ & \\
\hline $108-95-2$ & PHENOL . & $730^{\circ}$ & $\mathrm{ug} / \mathrm{kg}$ & $730:$ & $U$ & \\
\hline $111-44-4$ & BIS(2-CHLOROETHYL)ETHER & 730 & ug/kg & $730 !$ & $u$ & \\
\hline $95-57-8$ & 2-CHLOROPHENOL & $730:$ & ug/kg & $730 !$ & $u$ & \\
\hline $541-73-1$ & 1,3-DICHLOROBENZENE & 730 & $u g / \mathrm{kg}$ & 730 & $u$ & \\
\hline $106-46-7$ & 1,4-DICHLOROBENZENE & 730. & $\mathrm{ug} / \mathrm{kg}$ & $730:$ & $u$ & \\
\hline $95-50-1$ & 1.2-DICHLOROBENZENE & 730 & ug/kg & 7301 & $\mathrm{u}$ & \\
\hline $100-51-6$ & BENZYL ALCOHOL & 730 . & $u g / \mathrm{kg}$ & 730 : & $u$ & \\
\hline $108-60-1$ & BIS(2-CHLOROISOPROPYL)ETHER & 730 & $\mathrm{ug} / \mathrm{kg}$ & 730 & $u$ & \\
\hline $95-48-7$ & 2-METHYLPHENOL & 730 & ug/kg & $730:$ & $u$ & \\
\hline $621-64-7$ & N-NITROSO-DI-N-PROPYLAMINE & 730 & $4 \mathrm{~g} / \mathrm{kg}$ & $730 !$ & $\mathrm{U}$ & \\
\hline $106-44-5$ & 4METHYLPHENOL & 730 & $\mathrm{ug} / \mathrm{kg}$ & 7301 & $u$ & \\
\hline $67-72-1$ & HEXACHLOROETHANE & 730 & $\mathrm{ug} / \mathrm{kg}$ & 730 & $\mathrm{u}$ & \\
\hline $98-95-3$ & NITROBENZENE & 730 & $\mathrm{ug} / \mathrm{kg}$ & 730 & $u$ & \\
\hline $78-59-1$ & ISOPHORONE & 730 & $\mathrm{ug} / \mathrm{kg}$ & $730:$ & $U$ & \\
\hline $88-75-5$ & 2-NITROPHENOL & 730 & ug/kg & 730 & $u$ & \\
\hline $105-67-9$ & 2,4-OIMETHYLPHENOL & 730 & ug/kg & $730:$ & $\mathrm{u}$ & \\
\hline $111-91-1$ & BIS(2-CHLOROETMOXYMMETHANE & 730 & $\mathrm{ug} / \mathrm{kg}$ & 730 & $u$ & \\
\hline $120-83-2$ & 2,4-DICHLOROPHENOL & 730 & $u g / \mathrm{kg}$ & $730 !$ & $\mathrm{u}$ & \\
\hline $65-85-0$ & BENZOIC ACID & 3700 & $u g / \mathrm{kg}$ & $3700:$ & $u$ & \\
\hline $120-82-1$ & 1,2,4-TRICHLOROBENZENE & 730. & ug/kg & 730 & $u$ & \\
\hline $91-20-3$ & NAPHTHALENE & 730 & ug/kg & $730 !$ & $u$ & \\
\hline $106-47-8$ & 4-CHLOROANILINE & 1800 & ug/kg & $1800:$ & $u$ & \\
\hline $87-68-3$ & HEXACHLOROBUTADIENE & $730^{\prime}$ & $u g / \mathrm{kg}$ & $730 !$ & $u$ & \\
\hline $59-50-7$ & 4-CHLORO-3-METHYLPHENOL & $730:$ & $4 \mathrm{~g} / \mathrm{kg}$ & $730 !$ & u & \\
\hline $91-57-6$ & 2-METHYLNAPHTHALLENE & 730. & ug/kg & 730 : & $\bar{u}$ & \\
\hline $77-47-4$ & HEXACHLOROCYCLOPENTADIENE & $730:$ & $\mathrm{ug} / \mathrm{kg}$ & $730 !$ & $u$ & \\
\hline $88-06-2$ & 2,4,6-TRICHLOROPHENOL & $730:$ & ug/kg & $730 i$ & $u$ & \\
\hline $95-95-4$ & 2,4,5-TRICHLOROPHENOL & 730 & ug/kg & $730 !$ & $u$ & \\
\hline $91-58-7$ & 2-CHLORONAPHTHALENE & $730:$ & $\mathrm{ug} / \mathrm{kg}$ - & 7301 & $\mathrm{u}$ & \\
\hline $88-74-4$ & 2-NITROANLUNE & 3700 & ig/kg & $3700 !$ & $u$ & \\
\hline $131-11-3$ & OMETHYL PHTHALATE & $730:$ & $u g / \mathrm{kg}$ & 730 & $u$ & \\
\hline
\end{tabular}




\section{Semi-volatile Organics by GC/MS}

\section{Method SW8270}

Lab Name: Paragon Analytics, Inc.

Work Order Number: 9711092

Client Name: Washington State Dept. of Ecol

ClientProject ID: RCRA Closure of 303-K >

Reported on: Tuestay, November 18, 1997

Field ID: S3

Lab ID: $9711092-3$
Sample Matrix: solid

\% Moisture: 9.1 Cleanup Method: NONE

Report Basis: ORY WEIGHT
Date Coilected: 29-0ct-97

Date Extracted: 11-Nov-97

Date Analyzed: 14-Nov-97

Prop Bateh: sv11092 $\begin{array}{rr}\text { Sample Aliquot: } & 30 \\ \text { Final Volume: } & 1 \\ \text { Dilition: } & 2\end{array}$

\begin{tabular}{|c|c|c|c|c|c|}
\hline $606-20-2$ & 2,6-DINITROTOLUENE & $730^{\circ}$ & ug/kg & $730 !$ & U \\
\hline $208 \cdot 96-8$ & ACENAFHTHYLENE & 730 & tugikg & 7301 & $u$ \\
\hline $99-09-2$ & 3-NITROANILINE & 3700 & ug/kg & $3700 !$ & $\mathrm{u}$ \\
\hline $83-32-9$ & ACENAPHTHENE & $730^{\prime}$ & ug/kg & 7301 & $\mathrm{U}$ \\
\hline $51-28-5$ & 2,4-DINITROPHENOL & 3700: & $v g / \mathrm{kg}$ & 3700 & $u$ \\
\hline $100-02-7$ & 4-NITROPHENOL & 3700 & $u g / k g$ & 3700 & $u$ \\
\hline $132-64 \cdot 9$ & DIBENZOFURAN & 730 & ug/kg & $730 i$ & $\mathrm{U}$ \\
\hline $121-14-2$ & 2,4-DINITROTOLUENE & $730:$ & ug/kg & $730 i$ & $\mathrm{U}$ \\
\hline $84-66-2$ & DIETHYL PHTHALATE & 7301 & $\mathrm{ug} / \mathrm{kg}$ & 730 & $\mathbf{u}$ \\
\hline $86-73-7$ & FLUORENE & $730 i$ & ug/kg & $730 i$ & $\mathrm{U}$ \\
\hline $7005-72-3$ & 4CHLOROPHENYL PHENYL ETHER & $730 i$ & ugikg & 730 & $u$ \\
\hline $100-01-6$ & 4NITROANILINE & 3700 : & ugg/kg & 3700 & U \\
\hline $103-33-3$ & AZOBENZENE & 730 & ug/kg & 730 & U \\
\hline $534-52-1$ & 4,6-OINITRO-2-METHYLPHENOL & 3700 & $u g / \mathrm{kg}$ & $3700 !$ & $U$ \\
\hline $86-30-6$ & N-NITROSODIPHENYLAMINE & 7301 & ug/kg & 730 & $\mathrm{U}$ \\
\hline $101-55-3$ & 4-BROMOPHENYL PHENYL ETHER & $730 !$ & ug/kg & $730 i$ & $u$ \\
\hline $118-74-1$ & HEXACHLOROBENZENE & $730 !$ & $\mathrm{ug} / \mathrm{kg}$ & $730 !$ & $u$ \\
\hline $87-85-5$ & PENTACHLOROPHENCL & 3700 & $u g / \mathrm{kg}$ & $3700 !$ & 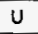 \\
\hline $85-01-8$ & PHENANTHRENE & $730^{\circ}$ & ugkikg & $730 !$ & $\mathrm{U}$ \\
\hline $120-12-7$ & ANTHRACENE & 730 & $u g / k g$ & $730 !$ & U \\
\hline $86-74-8$ & CARBAZOLE & $730:$ & ug/kg & 730 & U \\
\hline $84-74-2$ & DI-N-BUTYL PHTHALATE & $82:$ & ug/kg & 730 & $\mathrm{~J}, \mathrm{~B}$ \\
\hline $206-44-0$ & FLUORANTHENE & $730:$ & ug/kg & 730 & $\mathbf{u}$ \\
\hline $129-00-0$ & PYRENE & $730:$ & $u g / \mathrm{kg}$ & 730 & $U$ \\
\hline $85-68-7$ & BUTYL BENZYL PHTHALATE & 730: & $u g / k g$ & 730 & $U$ \\
\hline $56-55-3$ & BENZO(A)ANTHRACENE & 730 & $u g / \mathrm{kg}$ & 730 & U \\
\hline $91-94-1$ & 3,3'DICHLOROBENZIOINE & $3700 ：$ & $u g / \mathrm{kg}$ & 3700 & U \\
\hline $218-01-9$ & CHRYSENE & $730 !$ & ug/kg & 730 & $\mathrm{U}$ \\
\hline $117-81-7$ & BIS(2-ETHYLHEXYL)PHTHALATE & 80 & $\mathrm{ug} / \mathrm{kg}$ & 730 & \rfloor \\
\hline $117-84-0$ & DI-N-OCTYL PHTHALATE & 730 & $\mathrm{ug} / \mathrm{kg}$ & 7301 & $\mathrm{U}$ \\
\hline $205-99-2$ & BENZO(B K)FLUORANTHENE & 730 & ugikg & 730 & $\mathbf{U}$ \\
\hline $50-32-8$ & BENZO(A)PYRENE & $730:$ & $u g / \mathrm{kg}$ & 730 & $\mathrm{U}$ \\
\hline $193-39-5$ & INOENO $(1,2,3$-CD)PYRENE & $730:$ & $u g / \mathbf{k g}$ & 730 & U \\
\hline $53-70-3$ & DIBENZO(A,H)ANTHRACENE & 7301. & $u g / \mathbf{k g}-$ & 730 & $\mathrm{U}$ \\
\hline $191-24-2$ & BENZO(G,H,I)PERYLENE & $730:$ & ug/kg & 730 & $u$ \\
\hline
\end{tabular}




\section{Semi-volatile Organics by GC/MS}

Method SW8270

Lab Name: Paragon Analytics, Inc.

Work Order Number: 9711092

Client Name: Washington State Dept. of Ecol

ClientProject ID: RCRA Closure of 303-K >

Reported on: Tuesday, November 18.1997

Field ID: S3

Lab ID: 9711092.3
Sample Matrix: solid

\% Moisture: 9.1

Cleanup Method: NONE

Report Basis: DRY WEIGHT
Date Collected: 29-Oct-97

Date Extracted: 11-Nov-97

Date Analyzed: 14-Nov-97

Prep Batch: sv11092
Sample Aliquot: $\quad 30$

Final Volume:

Dilution:

\section{Surrogate Recovery}

\begin{tabular}{|l|l|c|c|c|c|c|}
\hline CASNO & Surrogate Analyte & Result & Units & $\begin{array}{c}\text { Spike } \\
\text { Amount }\end{array}$ & $\begin{array}{c}\text { Percent } \\
\text { Recovery }\end{array}$ & $\begin{array}{c}\text { Control } \\
\text { Limits }\end{array}$ \\
\hline $118-79-6$ & 2 -4,6-TRIBROMOPHENOL & 1720 & $\mathrm{ug} / \mathrm{kg}$ & 2500 & 69 & $19-113$ \\
\hline $321-60-8$ & 2-FLUOROBIPHENYL & 1030 & $\mathrm{ug} / \mathrm{kg}$ & 1670 & 62 & $30-105$ \\
\hline $367-12-4$ & 2-FLUOROPHENOL & 1450 & $\mathrm{ug} / \mathrm{kg}$ & 2500 & 58 & $25-100$ \\
\hline $4165-60-0$ & NITROBENZENE-D5 & $941:$ & $\mathrm{ug} / \mathrm{kg}$ & 1670 & 56 & $31-106$ \\
\hline $13127-88-3$ & PHENOL-DS & $1630: \mathrm{ug} / \mathrm{kg}$ & 2500 & 65 & $24-104$ \\
\hline $1718-51-0$ & TERPHENYL-D14 & $1550:$ & $\mathrm{ug} / \mathrm{kg}$ & 1670 & 93 & $18-112$ \\
\hline
\end{tabular}

$U=$ Less than the Reporting Limit 


\section{Semi-volatile Organics by GC/MS}

\section{Method SW8270}

Lab Name: Paragon Analytics, Inc.

Work Order Number: 9711092

Client Name: Washington State Dept. of Ecol

ClientProject ID: RCRA Closure of 303-K >

Reported on: Tuesday, November 18, 1997

Fiold tD: SS

Lab ID: $9711092-4$
Sample Matrix: solid

\% Moisture: 9

Cleanup Method: NONE

Report Basis: DRY WEIGHT
Date Collected: $30-O c t-97$

Date Extracted: 11-Nov-97

Date Analyzed: 14-Nov-97

Prep Batch: sv11092
Sample Aliquot: $\quad 30$

Final Volume: 1

Dilution: 2

\begin{tabular}{|c|c|c|c|c|c|c|}
\hline CASNO & Target Analyte & Result & Units & $\begin{array}{c}\text { Reporting } \\
\text { Limit }\end{array}$ & $\begin{array}{l}\text { Result } \\
\text { Qualifier }\end{array}$ & $\begin{array}{c}\text { Result } \\
\text { Footnote }\end{array}$ \\
\hline $110-86-1$ & PYRIDINE & $730 !$ & ug/kg & 730 & $\mathrm{U}$ & \\
\hline $62-75-9$ & N-NITROSODIMETHYLAMINE & 730 & $u g / \mathrm{kg}$ & $730 \vdots$ & $\mathrm{U}$ & \\
\hline $62-53-3$ & ANILINE & $1800:$ & $u g / \mathrm{kg}$ & 1800 & $\underline{U}$ & \\
\hline $108-95-2$ & PHENOL & 730 & $u g / \mathrm{kg}$ & 730 & $U$ & \\
\hline $111-44-4$ & BIS(2-CHLOROETHYL)ETHER & 730 & $u g / \mathrm{kg}$ & 730 & $\underline{U}$ & \\
\hline $95-57-8$ & 2-CHLOROPHENOL & $730:$ & $\mathrm{ug} / \mathrm{kg}$ & 730 : & $U$ & \\
\hline $541-73-1$ & 1,3-DICHLOROBENZENE & $730 !$ & ug/kg & 7301 & $\underline{U}$ & \\
\hline $106-46-7$ & 1.4-DICHLOROBENZENE & $730:$ & ug/ $\mathrm{kg}$ & $730 i$ & $\mathrm{U}$ & \\
\hline $95-50-1$ & 1.2-DICHLOROBENZENE & $730 !$ & $u g / \mathrm{kg}$ & 730 & U & \\
\hline $100-51-6$ & BENZYL ALCOHOL & 7301 & $u g / \mathrm{kg}$ & $730 i$ & U & \\
\hline $108-60-1$ & BIS(2-CHLOROISOPROPYL)ETHER & 730 : & $\mathrm{ug} / \mathrm{kg}$ & $730 !$ & $\underline{U}$ & \\
\hline $95-48-7$ & 2-METHYLPHENOL & 730 & ug/kg & 730 & $\mathrm{U}$ & \\
\hline $621-64-7$ & N-NITROSO-DI-N-PROPYLAMINE & 730 & ug/kg & 730 & u & \\
\hline $106-44-5$ & 4-METHYLPHENOL & 730 & $\mathrm{ug} / \mathrm{kg}$ & $730 !$ & $u$ & \\
\hline $67-72-1$ & HEXACHLOROETHANE & $730^{\circ}$ & $\mathrm{ug} / \mathrm{kg}$ & $730 ;$ & $\mathrm{U}$ & \\
\hline $98-95-3$ & NITROBENZENE & 730 & ugikg & $730:$ & $U$ & \\
\hline $78-59-1$ & ISOPHORONE & 730. & ug/kg & $730 !$ & $u$ & \\
\hline $88-75-5$ & 2-NITROPHENOL & 730 & $u g / \mathrm{kg}$ & $730:$ & $\mathrm{U}$ & \\
\hline $105-67-9$ & 2.4-DIMETHYLPHENOL & $730 !$ & $u g / k g$ & $730 !$ & $\mathrm{U}$ & \\
\hline $111-91-1$ & BIS(2-CHLOROETHOXY)METHANE & 730 : & $u g / k g$ & $730 i$ & $\mathrm{U}$ & \\
\hline $120-83-2$ & 2,4-DICHLOROPHENOL & $730 !$ & $u g / \mathrm{kg}$ & 730 & U & \\
\hline $65-85-0$ & BENZOIC ACID & $3700:$ & $u g / \mathrm{kg}$ & $3700:$ & $\mathrm{U}$ & \\
\hline 120-82-1. & 1.2,4-TRICHLOROBENZENE & $730:$ & ug/kg & $730 !$ & $\mathrm{u}$ & \\
\hline $91-20-3$ & NAPHTHALENE & $730 i$ & ug/kg & 730 & U & \\
\hline $106-47-8$ & 4-CHLOROANILINE & 1800. & $\mathrm{ug} / \mathrm{kg}$ & 1800: & $\underline{U}$ & \\
\hline $87-58-3$ & HEXACHLOROBUTADIENE & $730^{\prime}$ & ug/kg & $730 i$ & $\mathrm{U}$ & \\
\hline $59-50-7$ & 4-CHLORO-3-METHYLPHENOL & $730^{\prime}$ & $\mathrm{ug} / \mathrm{kg}$ & 7301 & $\mathrm{U}$ & \\
\hline $91-57-6$ & 2-METHYLNAPHTHALENE & $730:$ & $\mathrm{ug} / \mathrm{kg}$ & $730 \vdots$ & $\mathrm{U}$ & \\
\hline $77.47-4$ & HEXACHLOROCYCLOPENTADIENE & $730:$ & $u g / \mathrm{kg}$ & $730 \div$ & $\mathrm{U}$ & \\
\hline $88-06-2$ & 2,4,6-TRICHLOROPHENOL & 730 & $u g / k g$ & 730 & $\mathrm{U}$ & \\
\hline $95-95-4$ & 2,4,5-TRICHLOROPHENOL & $730 i$ & ug/kg & $730 i$ & $\bar{U}$ & \\
\hline $91-58-7$ & 2-CHLORONAPHTHALLENE & $730:$ & $\mathrm{ug} / \mathrm{kg}$ & $730 !$ & U & \\
\hline $88-74-4$ & 2-NITROANILINE & 3700 & tg $/ \mathrm{kg}$ & $3700 !$ & $\mathrm{u}$ & \\
\hline $131+11-3$ & DIMETHYL PHTHALATE & 730 & ug/kg & 7301 & $\bar{U}$ & \\
\hline
\end{tabular}




\section{Semi-volatile Organics by GC/MS}

\section{Method SW8270}

Lab Name: Paragon Analytics, ine.

Work Order Number: 9711092

Client Name: Washington State Dept. of Ecol

ClientProject ID: RCRA Closure of 303-K >

Reported on: Tuesday, November 18, 1997

Field JD: 55

Lab ID: 97110924
Sample Matrix: solid

$\%$ Moisture: 9

Cleanup Method: NONE

Report Basis: DRY WEIGHT
Date Collected: $30-0 \mathrm{ct}-97$

Date Extracted: 11-Nov-97

Date Analyzed: 14-Nov-97

Prep Batch: sv11092
Sample Aliquot:

Final Volume: Dilution:

\begin{tabular}{|c|c|c|c|c|c|}
\hline $606-20-2$ & 2,6-DINITROTOLUENE & $730^{\prime}$ & $\mathrm{ug} / \mathrm{kg}$ & $730 i$ & $\mathbf{u}$ \\
\hline $208-96-8$ & ACENAPHTHYLENE & 730 & ug/kg & $730 i$ & $u$ \\
\hline $99-09-2$ & 3-NITROANILINE & $3700:$ & $\mathrm{ug} / \mathrm{kg}$ & $3700 !$ & U \\
\hline $83-32-9$ & ACENAPHTHENE & $730:$ & ug/kg & $730:$ & $\mathbf{U}$ \\
\hline $51-28-5$ & 2.4-DINITROPHENOL & 3700 & ug/kg & $3700 !$ & $\mathbf{U}$ \\
\hline $100-02-7$ & 4-NITROPHENOL & 3700 & $u g / \mathrm{kg}$ & $3700^{\prime}$ & $\mathbf{u}$ \\
\hline $132-64-9$ & DIBENZOFURAN & $730^{\circ}$ & $u g / k g$ & $730 i$ & $\mathbf{U}$ \\
\hline $121-14-2$ & 2,4-DINITROTOLUENE & $730 i$ & ug/kg & $730 !$ & $u$ \\
\hline $84-66-2$ & DIETHYL PHTHALATE & 730: & $u g / k g$ & $730 !$ & $\mathbf{u}$ \\
\hline $86-73-7$ & FLUORENE & 7301 & $\mathrm{ug} / \mathrm{kg}$ & 7301 & $\mathbf{U}$ \\
\hline $7005-72-3$ & 4-CHLOROPHENYL PHENYL ETHER & 730 & $u g / k g$ & 730 & $\mathbf{U}$ \\
\hline $100-01-6$ & 4-NITROANILINE & $3700 !$ & $u g / k g$ & $3700 !$ & $\mathbf{u}$ \\
\hline $103-33-3$ & AZOBENZENE & 730 : & ug/kg & 730 & $\mathbf{u}$ \\
\hline $534-52-1$ & 4,6-DINITRO-2-METHYLPHENOL. & 3700 & $u g / k g$ & 3700 & $\mathrm{u}$ \\
\hline $86-30-6$ & N-NITROSODIPHENYLAMINE & $730 i$ & ug/kg & 730 & $\mathbf{U}$ \\
\hline $101-55-3$ & 4-BROMOPHENYL PHENYL ETHER & 730 & ug/kg & $730 i$ & $\mathbf{U}$ \\
\hline $118-74-1$ & HEXACHLOROBENZENE & $730:$ & $\mathrm{ug} / \mathrm{kg}$ & $730 !$ & U \\
\hline $87-86-5$ & PENTACHLOROPHENOL & 3700. & ug $/ \mathrm{kg}$ & $3700 i$ & $\mathbf{U}$ \\
\hline $85-01-8$ & PHENANTHRENE & 730 & ug/kg & $730 !$ & U \\
\hline $120-12-7$ & ANTHRACENE & 730. & ug/kg & $730 i$ & $u$ \\
\hline $86-74.8$ & CARBAZOLE & $730 !$ & ug/kg & 730 & $\mathbf{u}$ \\
\hline $84-74-2$ & DI-N-BUTYL PHTHALATE & $730:$ & ug/kg & 730 & $\mathbf{U}$ \\
\hline $206-44-0$ & FLUORANTHENE & $730:$ & $\mathrm{ug} / \mathrm{kg}$ & 730 & U \\
\hline $129-00-0$ & PYRENE & 730 & $u g / k g$ & $730 i$ & $\mathrm{U}$ \\
\hline $85-68-7$ & BUTYL BENZYL PHTHALATE & $730^{\circ}$ & $\mathrm{ug} / \mathrm{kg}$ & $730 i$ & $\mathbf{U}$ \\
\hline $56-55-3$ & BENZO(A)ANTHRACENE & 730 ; & ug/kg & 730 & $\mathbf{u}$ \\
\hline $91-94-1$ & 3.3'-DICHLOROBENZIDINE & 3700 & $u g / \mathrm{kg}$ & 3700 & $\mathbf{U}$ \\
\hline 218-01-9 & CHRYSENE & 730: & $\mathbf{u g} / \mathbf{k g}$ & 730 & $\mathbf{u}$ \\
\hline $117-81-7$ & BIS(2-ETHYLHEXYL)PHTHALATE & $130 i$ & $u g / \mathrm{kg}$ & 730 & $J$ \\
\hline $117-84-0$ & DI-N-OCTYL PHTHALATE & 730 & ug/kg & 730 & $\mathrm{U}$ \\
\hline $205-99-2$ & BENZO(B.K)FLUORANTHENE & 730: & ug/kg & 730 & $\mathbf{U}$ \\
\hline $50-32-8$ & BENZO(A)PYRENE & $730^{\prime}$ & $\mathbf{u g} / \mathbf{k g}$ & 730 & $U$ \\
\hline $193-39-5$ & INDENO $(1,2,3-C D) P Y R E N E$ & 7301 & $u g / \mathrm{kg}$ & 730 & $\mathbf{U}$ \\
\hline $53-70-3$ & DIBENZO(A.K)ANTHRACENE & $730 !$ & ug/kg - & 730 & $U$ \\
\hline $191-24-2$ & BENZO(G.H.J)PERYLENE & 730: & ug/kg & 730 & $\mathbf{U}$ \\
\hline
\end{tabular}




\section{Semi-volatile Organics by GC/MS \\ Method SW8270}

Lab Name: Paragon Analytics, Inc.

Work Order Number: 9711092

Client Name: Washington State Dept. of Ecol

ClientProject ID: RCRA Closure of 303-K >

Reported on: Tuesday. November 18, 1997

Field ID: 55

Lab ID: $9711092-4$
Sample Matrix: solid

$\%$ Moisture: 9

Cleanup Mothod: NONE

Report Basis: DRY WEIGHT
Date Collected: $30-0 c t-97$

Date. Extracted: 11-Nov-97

Date Analyzed: 14-Nov-97

Prep Batch: sv11092

\section{Sample Aliquat: $\quad 30$ \\ Final Volume: 1 \\ Dilution: 2}

\section{Surrogate Recovery}

\begin{tabular}{|c|c|c|c|c|c|c|}
\hline CASNO & Surrogate Analyte & Result & Units & $\begin{array}{l}\text { Spike } \\
\text { Amount }\end{array}$ & $\begin{array}{l}\text { Percent } \\
\text { Recovery }\end{array}$ & $\begin{array}{l}\text { Control } \\
\text { Limits }\end{array}$ \\
\hline $118-79-6$ & 2,4,6-TRIBROMOPHENOL & 1330 & ug/kg & 2500 & 53 & $19 \cdot 113$ \\
\hline $321-60-8$ & 2-FLUOROBIPHENYL & 823 & ug/kg & 1670 & 49 & $30-105$ \\
\hline $367-12-4$ & 2-FLUOROPHENOL & 1070 & ug/kg & 2500 & 43 & $25-100$ \\
\hline $4165-60-0$ & NITROBENZENE-D5 & 737 & $u g / k g$ & 1670 & 44 & $31 \cdot 106$ \\
\hline $13 \div 27-88-3$ & PHENOL-D5 & 1300 & ug/kg & 2500 & 52 & $24 \cdot 104$ \\
\hline $1718-51-0$ & TERPHENYL-D14 & 1190 & $\mathrm{ug} / \mathrm{kg}$ & 1670 & 72 & $18-112$ \\
\hline
\end{tabular}

$U=$ Less than the Reporting Limit 


\section{Semi-volatile Organics by GC/MS}

\section{Method SW8270}

Lab Name: Paragon Analytics, Inc.

Work Order Number: 9711092

Client Name: Washington State Dept. of Eco!

ClientProject ID: - RCRA Closure of 303-K >

Reported on: Tuesday, November 18, 1997

Fleld ID: $\mathbf{S 6}$

Lab ID: $9711092-5$
Sample Matrix: solid

\% Moisture: 6.9

Cleanup Method: NONE

Report Basis: DRY WEIGHT
Date Collected: 29-Oct-97

Date Extracted: 11-Nov-97

Date Analyzed: 14-Nov-97

Prep Batch: sv11092
Samplo Aliquot:

Final Volume:

Dilution:
30

1

2

\begin{tabular}{|c|c|c|c|c|c|c|}
\hline CASNO & Target Analyte & Result & Units & $\begin{array}{c}\text { Reporting } \\
\text { Limit }\end{array}$ & $\begin{array}{l}\text { Result } \\
\text { Qualifier }\end{array}$ & $\begin{array}{l}\text { Result } \\
\text { Footnote }\end{array}$ \\
\hline $110-86-1$ & PYRIDINE & 720 & ug/kg & $720:$ & $U$ & \\
\hline $62-75-9$ & N-NITROSODIMETHYLAMINE & 720 & ug/kg & 720 & U & \\
\hline $62-53-3$ & ANILINE & 1800 & $\mathrm{ug} / \mathrm{kg}$ & 1800 & $U$ & \\
\hline $108-95-2$ & PHENOL & 720 & ug/kg & 720 & U & \\
\hline $111-44-4$ & BIS(2-CHLOROETHYL)ETHER & 720 & $4 g / \mathrm{kg}$ & $720 ：$ & $u$ & \\
\hline $95-57-8$ & 2-CHLOROPHENOL & 720 & $u g / \mathrm{kg}$ & $720 i$ & $\mathrm{U}$ & \\
\hline $541-73-1$ & 1,3-DICHLOROBENZENE & 720 & $u g / k g$ & $720 !$ & $u$ & \\
\hline $106-46-7$ & 1,4-DICHLOROBENZENE & 720 & ug/kg & $720 !$ & $U$ & \\
\hline $95-50-1$ & 1.2-DICHLOROBENZENE & $720^{\circ}$ & $u g / k g$ & 720 & $\mathbf{u}$ & \\
\hline $100-51-6$ & BENZYLALCOHOL & 720 & ug/kg & 720 & $\mathrm{U}$ & \\
\hline $108-60-1$ & BIS(2-CHLOROISOPROPYL)ETHER & 720 & $u g / \mathrm{kg}$ & $720 !$ & $\mathrm{u}$ & \\
\hline $95-48-7$ & 2-METHYLPHENOL & 720 & $u g / \mathrm{kg}$ & $720 !$ & $\mathrm{U}$ & \\
\hline $621-64-7$ & N-NITROSO-DI-N-PROPYLAMINE & 720 & $\mathrm{ug} / \mathrm{kg}$ & 720 & $\mathrm{U}$ & \\
\hline $106-44-5$ & A-METHYLPHENOL & 720 & $\mathrm{ug} / \mathrm{kg}$ & $720 !$ & $\mathrm{U}$ & \\
\hline $67-72-1$ & HEXACHLOROETHANE & 720 & ug/kg & $720 !$ & U & \\
\hline $98-95-3$ & NITROBENZENE & 720 & ug/kg & $720 i$ & $\mathrm{U}$ & \\
\hline $78-59-1$ & ISOPHORONE & 720 & ug/kg & $720 !$ & $\mathbf{u}$ & . \\
\hline $88-75-5$ & 2-NITROPHENOL & 720 & $\mathrm{ug} / \mathrm{kg}$ & $720 !$ & $\mathrm{U}$ & \\
\hline $105-67.9$ & 2.4-DIMETHYLPHENOL & 720 & ug $/ \mathrm{kg}$ & $720 !$ & $u$ & \\
\hline $111-91-1$ & BIS(2-CHLOROETHOXY)METHANE & 720 & $u g / k g$ & $720 !$ & $u$ & \\
\hline $120-83-2$ & 2,4-DICHLOROPHENOL & 720 & $\mathrm{ug} / \mathrm{kg}$ & $720 !$ & $\mathbf{u}$ & \\
\hline $65-85-0$ & BENZOIC ACID & 3600 & $\operatorname{ug} / \mathrm{kg}$ & 3600 & $\mathbf{u}$ & \\
\hline $120-82-1$ & 1,2,4-TRICHLOROBENZENE & 720 & $u g / \mathrm{kg}$ & $720 i$ & u & \\
\hline $91-20-3$ & NAPHTHALENE & 720 & ug/kg & $720 !$ & $\mathbf{U}$ & \\
\hline $106-47-8$ & 4-CHLOROANILINE & 1800 & $u g / \mathrm{kg}$ & 1800 & $\mathbf{U}$ & \\
\hline $87-68-3$ & HEXACHLOROBUTADIENE & 720 & $u g / k g$ & $720 !$ & $\mathbf{u}$ & \\
\hline $59-50-7$ & 4-CHLORO-3-METHYLPHENOL & 720 & $u g / \mathrm{kg}$ & $720 i$ & $\mathbf{u}$ & \\
\hline $91-57-6$ & 2-METHYLNAPHTHALENE & 720 & ug $/ \mathrm{kg}$ & $720 i$ & $\mathbf{u}$ & \\
\hline $77-47-4$ & HEXACHLOROCYCLOPENTAOIENE & 720 & $\mathrm{ug} / \mathrm{kg}$ & $720 i$ & $\mathrm{u}$ & \\
\hline $88-06-2$ & 2,4,6-TRICHLOROPHENOL & 720 & ug/kg & 720 & $\mathbf{u}$ & \\
\hline $95-95-4$ & 2.4.5-TRICHLOROPHENOL & 720 & $u g / \mathrm{kg}$ & 720 & $\mathbf{U}$ & \\
\hline $91-58-7$ & 2-CHLORONAPHTHALENE & 720 & ug/kg $=$ & 720 & $U$ & \\
\hline $88-74-4$ & 2-NITROANILINE & 3600 & $\mathrm{ug} / \mathrm{kg}$ & 3600 & U & \\
\hline $131-11-3$ & DIMETHYL PHTHALATE & 720 & $u g / k g$ & 7201 & $u$ & \\
\hline
\end{tabular}




\section{Semi-volatile Organics by GC/MS}

\section{Method SW8270}

Lab Name: Paragon Analytics, Inc.

Work Order Number: 9711092

Client Name: Washington State Dept. of Ecol

ClientProject ID: RCRA Closure of 303-K >

Reported on: Tuesday, November 18. 1997

Field tD: $S 6$

Lab ID: $9711092-5$
Sample Matrix: solid

$\%$ Moisture: 6.9 Cleanup Method: NONE Report Basis: DRY WEIGHT
Date Collected: 29-0ct-97

Date Extracted: 11-Nov-97

Date Analyzed: 14-Nov-97 Prep Batch: sv11092
Sample Aliquot: $\quad 30$

Final Volume: $\quad 1$

Dilution: 2

\begin{tabular}{|c|c|c|c|c|c|}
\hline $606-20-2$ & 2.6-DINITROTOLUENE & $720 !$ & ug/kg & 720 & $U$ \\
\hline 208-96-8 & ACENAPHTHYLENE & $720:$ & $u g / \mathrm{kg}$ & 720 & $\mathrm{U}$ \\
\hline $99-09-2$ & 3-NITROANILINE & $3600_{i}$ & ug/kg & 3600 & $\mathrm{u}$ \\
\hline $83-32-9$ & ACENAPHTHENE & $720^{\circ}$ & $u g / k g$ & 720 & $\mathrm{U}$ \\
\hline $51-28-5$ & 2,4-OINITROPHENOL & 3600 : & $\omega g / \mathrm{kg}$ & 3600 & $\mathbf{U}$ \\
\hline $100-02-7$ & 4-NITROPHENOL & $3600:$ & $\mathrm{ug} / \mathrm{kg}$ & 3600 & $\mathrm{U}$ \\
\hline $132-64-9$ & DIBENZOFURAN & 720 & $\mathrm{ug} / \mathrm{kg}$ & 720 & $u$ \\
\hline $121-14-2$ & 2.4-DINITROTOLUENE & 720 & ug/kg & $720 !$ & $\mathrm{u}$ \\
\hline $84-66-2$ & DIETHYL PHTHALATE & $720 !$ & $u g / \mathrm{kg}$ & $720 i$ & $u$ \\
\hline $86-73-7$ & FLUORENE & 7201 & ug/kg & $720 !$ & $u$ \\
\hline $7005-72-3$ & 4-CHLOROPHENYL PHENYL ETHER & $720 !$ & $u g / \mathrm{kg}$ & $720 !$ & $u$ \\
\hline $100-01-6$ & 4-NITROANIEINE & $3600 !$ & ug/kg & 3600 & $\mathrm{u}$ \\
\hline $103-33-3$ & AZOBENZENE & $720:$ & $\mathrm{ug} / \mathrm{kg}$ & 720 & $U$ \\
\hline $534-52-1$ & 4,6-DINITRO-2-METHYLPHENOL & 3600 & $\mathrm{ug} / \mathrm{kg}$ & 3600 & $u$ \\
\hline $86-30-6$ & N-NITROSODIPHENYLAMINE & 720 & ug/kg & $720 !$ & $u$ \\
\hline $101-55-3$ & 4-BROMOPHENYL PHENYL ETHER & $720:$ & $u g / k g$ & $720 !$ & $\mathbf{u}$ \\
\hline $118-74-1$ & HEXACHLOROBENZENE & $720:$ & $u g / k g$ & $720 i$ & $\mathrm{U}$ \\
\hline $37 \cdot 86-5$ & PENTACHLOROPHENOL & $3600:$ & $u g / \mathrm{kg}$ & 3600 & $\mathrm{u}$ \\
\hline $85-01-8$ & PHENANTHRENE & 720. & $\mathrm{ug} / \mathrm{kg}$ & 720 : & $\mathrm{U}$ \\
\hline $120-12-7$ & ANTHRACENE & 720 & $\mathrm{ug} / \mathrm{kg}$ & 720 : & $u$ \\
\hline $36 \cdot 74-8$ & CAREAZOLE & $720:$ & ug/kg & $720 i$ & $u$ \\
\hline 84-74-2 & DI-N-BUTYL PHTHALATE & $91:$ & ug/kg & 720 & $\mathrm{~J}, \mathrm{~B}$ \\
\hline $206 \cdot 44.0$ & FLUORANTHENE & 720 & ug/kg & $720 !$ & $u$ \\
\hline $129-00-0$ & PYRENE & 720: & $49 / \mathrm{kg}$ & $720 !$ & $\mathrm{U}$ \\
\hline $85-68-7$ & BUTYL BENZYL PHTHALATE & $720:$ & ug/kg & $720 i$ & U \\
\hline $56-55-3$ & BENZO(A)ANTHRACENE & 720 : & $u g / \mathrm{kg}$ & $720 i$ & $\mathrm{U}$ \\
\hline $91-94-1$ & 3.3'-DICHLOROBENZIDINE & 3600 & $u g / \mathrm{kg}$ & 3600 & 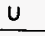 \\
\hline $218-01-9$ & CHRYSENE & 720 & $u g / \mathrm{kg}$ & 720 & $U$ \\
\hline $117-81 \cdot 7$ & BIS(2-ETHYLHEXYL)PHTHALATE & $720 !$ & ug/kg & $720 !$ & $U$ \\
\hline $117-84-0$ & DI-N-OCTYL PHTHALLATE & $720:$ & $u g / \mathrm{kg}$ & $720 !$ & $\mathrm{U}$ \\
\hline 205-99-2 & BENZO(B.K)FLUORANTHENE & $720:$ & $\mathrm{ug} / \mathrm{kg}$ & $720 i$ & $\mathbf{U}$ \\
\hline $50-32-8$ & BENZO(A)PYRENE & $720 !$ & ug/kg & $720 ：$ & U \\
\hline $193-39-5$ & INDENO(1,2.3-CD)PYRENE & $720 !$ & $u g / \mathrm{kg}$ & 7201 & $\mathbf{U}$ \\
\hline $3-70-3$ & DIBENZO(A.H)ANTHRACENE & $720:$ & $\mathrm{ug} / \mathrm{kg}$ & 720 & $\mathrm{u}$ \\
\hline $91-24-2$ & BENZO(G.H.I)PERYLENE & 7201 & ug/kg & $720 !$ & $\mathbf{u}$ \\
\hline
\end{tabular}




\section{Semi-volatile Organics by GC/MS}

Method SW8270

Lab Name: Paragon Aralytics, Inc.

Work Order Number: 9711092

Client Name: Washington State Dept. of Ecol

ClientProject to: RCRA Closure of 303-K>

Reported on: Tuesday, November 18, 1997

Field 10 : S6

Lab ID: 9711092-5
Sample Matrix: solid

\% Moisture: 6.9

Cleanup Method: NONE

Report Basis: DRY WEIGHT
Date Collected: 29-0ct-97

Date Extracted: 11-Nov-97

Date Analyzed: 14-Nov-97

Prop Batch: sv1 1092
Sample Aliquot: $\quad 30$

Final Volume: 1

Dilution: 2

\section{Surrogate Recovery}

\begin{tabular}{|c|c|c|c|c|c|c|}
\hline CASNO & Surrogate Anaiyte & Result & Units & $\begin{array}{l}\text { Spike } \\
\text { Amount }\end{array}$ & $\begin{array}{l}\text { Percent } \\
\text { Recovery }\end{array}$ & $\begin{array}{c}\text { Control } \\
\text { Limits }\end{array}$ \\
\hline $118-79-6$ & 2,4,6-TRIBROMOPHENOL & 1610 & $u g / \mathbf{k g}$ & 2500 & 64 & $19-113$ \\
\hline $32 i-60-8$ & 2-FLUOROBIPHENYY & 1010 & $u g / \mathrm{kg}$ & 1670 & 60 & $30-105$ \\
\hline $367-12-4$ & 2-FLUOROPHENOL & 1240 & ug/kg & 2500 & 49 & $25-100$ \\
\hline $4165-60-0$ & NITROBENIZENE-DS & 960 & ug/ $/ \mathrm{kg}$ & 1670 & 58 & $31-106$ \\
\hline $13127-88-3$ & PHENOL-D5 & 1600 & $u g / \mathrm{kg}$ & 2500 & 64 & $24-104$ \\
\hline $1718-51-0$ & TERPHENYL-D14 & 1330 & ug/kg & 1670 & 80 & $18-112$ \\
\hline
\end{tabular}

$U=$ Less than the Reporting Limit 


\section{Semi-volatile Organics by GC/MS}

\section{Method SW8270}

Lab Name: Paragon Analytics, Inc.

Work Order Number: 9711092

Client Name: Washington State Dept. of Ecol

ClientProject ID: RCRA Closure of 303-K >

Roported on: Tuesday, November 18, 1997

Fiold ID: 57

Lab ID: $9711092-6$
Sample Matrix: solid

$\%$ Moisture: 8.7

Cleanup Method: NONE

Report Basis: DRY WEIGHT
Date Collected: 29-Oct-97

Date Extracted: 11-Nov-97

Date Analyzed: 14-Nov-97

Prep Batch: sv 11092
Sample Aliquot: 30

Final Volume: $\quad 1$ Dilution: 2

\begin{tabular}{|c|c|c|c|c|c|c|}
\hline CASNO & Target Analyte & Result & Units & $\begin{array}{c}\text { Reporting } \\
\text { Limit }\end{array}$ & $\begin{array}{l}\text { Result } \\
\text { Qualifier }\end{array}$ & $\begin{array}{l}\text { Result } \\
\text { Footnote }\end{array}$ \\
\hline $110-86-1$ & PYRIDINE & $730^{\circ}$ & $\mathrm{ug} / \mathrm{kg}$ & $730 !$ & $u$ & \\
\hline $62-75-9$ & N-NITROSODIMETHYLAMINE & 730 & $u g / \mathrm{kg}$ & $730 i$ & $\mathrm{U}$ & \\
\hline $62-53-3$ & ANILINE & 1800 & $\mathrm{ug} / \mathrm{kg}$ & 1800 & $\mathrm{U}$ & \\
\hline $108-95-2$ & PHENOL & $730^{\circ}$ & ug $/ \mathrm{kg}$ & $730:$ & $u$ & \\
\hline $111-44-4$ & BIS(2-CHLOROETHYL)ETHER & $730:$ & $u g / k g$ & 730 : & $\mathrm{u}$ & \\
\hline $95-57-8$ & 2-CHLOROPHENOL & $730 !$ & $u g / \mathrm{kg}$ & $730 !$ & $U$ & \\
\hline $541-73-1$ & 1,3-DICHLOROBENZENE & 730 & ug/kg & $730 i$ & $U$ & \\
\hline $106-46-7$ & 1,4-DICHLOROBENZENE & $730 !$ & $u g / \mathrm{kg}$ & $730 i$ & $\mathrm{U}$ & \\
\hline $95-50-1$ & 1,2-DICHLOROBENZENE & $730:$ & ug/kg & $730 i$ & U & \\
\hline $100-51-6$ & BENZYL ALCOHOL & 730 & ug/kg & $730 !$ & $U$ & \\
\hline $108-60-1$ & BIS(2-CHLOROISOPROPYL)ETHER & 730 & $49 / \mathrm{kg}$ & $730 \vdots$ & $\mathrm{U}$ & \\
\hline $95-48-7$ & 2-METHYLPHENOL & 730 & $\mathrm{ug} / \mathrm{kg}$ & 730 & $U$ & \\
\hline $621-64-7$ & N-NITROSO-OI-N-PROPYLAMINE & 730 & ug/kg & $730 ：$ & $\mathrm{u}$ & \\
\hline $106-44-5$ & 4-METHYLPHENOL & 730 : & $u g / \mathrm{kg}$ & 7301 & $\mathrm{U}$ & \\
\hline $67-72-1$ & HEXACHLOROETHANE & $730:$ & ug/kg & $730 !$ & U & \\
\hline $98-95-3$ & NITROBENZENE & 730 & $u g / k g$ & 7301 & U & \\
\hline $78-59-1$ & ISOPHORONE & 730 & $\mathrm{ug} / \mathrm{kg}$ & $730 !$ & $U$ & \\
\hline $88-75-5$ & 2-NITROPHENOL & 730 & ug/kg & $730:$ & $\mathrm{U}$ & \\
\hline $105-67-9$ & 2,4-DIMETHYLPHENOL & 730 : & $\mathrm{ug} / \mathrm{kg}$ & $730 !$ & $\mathrm{U}$ & \\
\hline $111-91-1$ & BIS(2-CHLOROETHOXY)METHANE & 730 & $u g / \mathrm{kg}$ & $730 !$ & $u$ & \\
\hline $120-83-2$ & 2.4-DICHLOROPHENOL & $730 !$ & $u g / \mathrm{kg}$ & $730:$ & $\mathrm{U}$ & \\
\hline $65-85-0$ & BENZOIC ACID & $3700:$ & $\mathrm{ug} / \mathrm{kg}$ & $3700 ;$ & $\mathrm{U}$ & \\
\hline $120-82-1$ & 1.2.4-TRICHLOROBENZENE & 730 & $\mathrm{ug} / \mathrm{kg}$ & $730 \vdots$ & $\mathrm{U}$ & \\
\hline $91-20-3$ & NAPHTHALENE & $730:$ & $\mathrm{ug} / \mathrm{kg}$ & $730 !$ & $U$ & \\
\hline $106-47-8$ & 4-CHLOROANILINE & 1800 & $u g / k g$ & $1800 !$ & U & \\
\hline $87-68-3$ & HEXACHLOROBUTADIENE & $730^{\prime}$ & $u g / \mathrm{kg}$ & $730 !$ & $\mathbf{U}$ & \\
\hline $59-50-7$ & 4-CHLORO-3-METHYLPHENOL & $730^{\circ}$ & $\mathbf{u g} / \mathbf{k g}$ & $730 !$ & $\mathrm{U}$ & \\
\hline $91-57-6$ & 2-METHYLNAPHTHALENE & 730 & $\mathrm{ug} / \mathrm{kg}$ & $730 !$ & $\mathrm{u}$ & \\
\hline $77-47-4$ & HEXACHLOROCYCLOPENTADIENE & 730 & $u g / \mathrm{kg}$ & $730 !$ & $\mathrm{U}$ & \\
\hline $88-06-2$ & 2,4,6-TRICHLOROPHENOL & 730 : & $u g / \mathrm{kg}$ & $730 i$ & U & \\
\hline $95-95-4$ & 2.4.5-TRICHLOROPHENOL & 730 ! & $\mathrm{ug} / \mathrm{kg}$ & 730 & U & \\
\hline $91-58-7$ & 2-CHLORONAPHTHALENE & $730^{\prime}$ & $\mathrm{ug} / \mathrm{kg}$. & 730 & $\mathbf{u}$ & \\
\hline $88-74-4$ & 2-NITROANILINE & 3700 & $u g / k g$ & $3700 !$ & $U$ & \\
\hline $131-11-3$ & DIMETHYL PHTHALATE & 730 & $u g / \mathrm{kg}$ & $730 !$ & $u$ & \\
\hline
\end{tabular}




\section{Semi-volatile Organics by GC/MS}

\section{Method SW8270}

Lab Name: Paragon Analytics, ine.

Work Order Number: 9711092

Client Name: Washington State Dept. of Ecol

ClientProject ID: RCRA Closure of 303-K >

Reported on: Tuesday, November 18, 1997

Field 1D: 57

Lab ID: $9711092-6$
Sample Matrix: solid

$\%$ Moisture: 8.7

Cleanup Method: NONE Roport Basis: DRY WEIGHT
Date Collected: $29-0 \mathrm{ct}-97$

Date Extracted: $11-$ Nov-97

Date Analyzed: 14-Nov-97

Prep Batch: sv 11092
Sample Aliquot:

Final Volume:

Dilution:

\begin{tabular}{|c|c|c|c|c|c|}
\hline $606-20-2$ & 2,6-DINTROTOLUENE & 730 & $u g / \mathrm{kg}$ & $730 \vdots$ & $\mathrm{U}$ \\
\hline $208-96-8$ & ACENAPHTHYLENQE & 730 & $u g / \mathrm{kg}$ & $730:$ & $u$ \\
\hline $99 \cdot 09 \cdot 2$ & 3-NITROANILINE & 3700 & $u g / \mathrm{kg}$ & $3700:$ & $\mathrm{U}$ \\
\hline 83-32-9 & ACENAPHTHENE & 730 & ug/kg & 730 & $\mathrm{U}$ \\
\hline $5 i-28-5$ & 2.4-DINITROPHENOL & 3700 & ug $/ \mathrm{kg}$ & 3700 & u \\
\hline $100-02-7$ & 4-NITROPHENOL & 3700 & $u g / \mathrm{kg}$ & 3700 & $\underline{U}$ \\
\hline $132-64-9$ & DIBENZOFURAN & 730 & ug/kg & 730 & $\mathrm{u}$ \\
\hline $121-14-2$ & 2.4-DINITROTOLUENE & 730 & $u g / \mathrm{kg}$ & 730 & $\mathrm{U}$ \\
\hline $84-66-2$ & DIETHYL PHTHALATE & 730 & $u g / \mathrm{kg}$ & 7301 & U \\
\hline $86-73-7$ & FLUORENE & 730 & $u g / \mathrm{kg}$ & 730 & $\underline{U}$ \\
\hline $7005-72-3$ & 4-CHLOROPHENYL PHENYL ETHER & 730 & ug/kg & 730 & U \\
\hline $100-01-6$ & 4NITROANILINE & 3700 & $u g / \mathrm{kg}$ & 3700 & $\mathbf{U}$ \\
\hline $103-33-3$ & AZOBENZENE & 730 & $u g / \mathrm{kg}$ & 730 & $\mathrm{U}$ \\
\hline $534-52-1$ & 4,6-DINITRO-2-METHYLPHENOL & 3700 & $u g / \mathrm{kg}$ & 3700 & $\mathrm{U}$ \\
\hline $86-30-6$ & N-NITROSODIPHENYLAMINE & 730 & $u g / \mathrm{kg}$ & 730 & $u$ \\
\hline $101.55-3$ & 4-BROMOPHENYL PHENYL ETHER & 730 & $u g / \mathrm{kg}$ & 730 & $\mathrm{u}$ \\
\hline $118-74-1$ & HEXACHLOROBENZENE & 730 & ug/kg & $730 !$ & $\mathrm{U}$ \\
\hline $87-86-5$ & PENTACHLOROPHENOL & 3700 & $u g / \mathrm{kg}$ & 3700 i & $u$ \\
\hline $85-01-8$ & PHENANTHRENE & 730 & ug/kg & 730 & $\mathrm{U}$ \\
\hline $120-12-7$ & ANTHRACENE & 730 & ug/kg & $730 !$ & $\mathrm{U}$ \\
\hline $86-74-8$ & CARBAZOLE & 730 & ug/kg & $730 i$ & U \\
\hline $84-74-2$ & DI.N-BUTYL PHTHALATE & 140 & ug/kg & 7301 & $\mathrm{~J}, \mathrm{~B}$ \\
\hline $206-44-0$ & FLUORANTHENE & 730 & ug/kg & $730 i$ & $U$ \\
\hline $129-00-0$ & PYRENE & 730 & $u g / \mathrm{kg}$ & 730 & U \\
\hline $85-68-7$ & BUTYL BENZYL PHTMALATE & 730. & $u g / \mathrm{kg}$ & $730 !$ & $\mathrm{U}$ \\
\hline $56-55-3$ & BENZO(A)ANTHRACENE & 730 & $u g / \mathrm{kg}$ & 730 & $u$ \\
\hline $91-94-1$ & 3.3'-DICHLOROBENZIDINE & 3700 & $u g / \mathrm{kg}$ & 3700 & $\mathrm{u}$ \\
\hline $218-01-9$ & CHRYSENE & 730 & $u g / \mathrm{kg}$ & 730 & $\mathrm{U}$ \\
\hline $117-81-7$ & BIS(2-ETHYLHEXYL)PHTHALATE & $730^{\circ}$ & $u g / \mathrm{kg}$ & $730 i$ & $\mathrm{U}$ \\
\hline $117-84.0$ & DI-N-OCTYL PHTHALATE & 730 & ug/kg & 730 & $\mathrm{u}$ \\
\hline $205-99-2$ & BENZO(B.K)FLUORANTHENE & 730 & ug $/ \mathrm{kg}$ & 730 & $\mathrm{U}$ \\
\hline $50-32-8$ & BENZO(A)PYRENE & 730 & $u g / \mathrm{kg}$ & 730 & $\mathrm{U}$ \\
\hline $193-39-5$ & INDENO(\{,2,3-CD\}PYRENE & 730 & ug/kg & 730 & $\mathrm{U}$ \\
\hline $53-70-3$ & DIBENZO(A.H)ANTHRACENE & 730 & $u g / k g$ & 730 & $\mathrm{U}$ \\
\hline $191-24-2$ & BENZO(G.H.I)PERYLENE & 730 & ug/kg & 730 & U \\
\hline
\end{tabular}




\section{Semi-volatile Organics by GC/MS}

\section{Method SW8270}

Lab Name: Paragon Analyties, Ine.

Work Order Number: 9711092

Client Name: Washington State Dept. of Ecot

ClientProject ID: RCRA Closure of 303-K >

Reported on: Tuesday, November 18, 1997

Field ID: S7

Lab ID: $9711092-6$
Sample Matrix: solid

$\%$ Moisture: 8.7

Cleanup Method: NONE

Report Basis: DRY WEIGHT
Date Collected: $29-0 \mathrm{ct}-97$

Date Extracted: 11-Nov-97

Date Analyzed: 14-Nov-97

Prep Batch: sv1 1092
Sample Aliquot:

Final Volume:

Dilution:

\section{Surrogate Recovery}

\begin{tabular}{|c|c|c|c|c|c|c|}
\hline CASNO & Surrogate Analyte & Result & Units & $\begin{array}{l}\text { Spike } \\
\text { Amount }\end{array}$ & $\begin{array}{l}\text { Percent } \\
\text { Recovery }\end{array}$ & $\begin{array}{c}\text { Control } \\
\text { Limits }\end{array}$ \\
\hline $118-79-6$ & 2,4.6-TRIBROMOPHENOL & 1700 & ug/kg & 2500 & 68 & $19-113$ \\
\hline $321-60-8$ & 2-FLUOROBIPHENYL & 11190 & $u g / k g$ & 1670 & 67 & $30-105$ \\
\hline $367-12-4$ & 2.FLUOROPHENOL & 1460 & ug/kg & 2500 & 58 & $25-100$ \\
\hline $4165-60-0$ & NITROBENZENE-DS & 972 & ug/kg & 1670 & 58 & $31-106$ \\
\hline $13127-88-3$ & PHENOL-DS & 1750 & ug/kg & 2500 & 70 & $24-104$ \\
\hline $1718-51-0$ & TERPHENYL-D14 & 1610 & ug/kg & 1670 & 97 & $18-112$ \\
\hline
\end{tabular}

$U=$ Less than the Reporting Limit 


\section{Semi-volatile Organics by GC/MS}

\section{Method SW8270}

Lab Name: Paragon Analyties, inc.

Work Order Number: 9711092

Client Name: Washington State Dept. of Ecol

ClientProject ID: RCRA Closure of 303-K >

Reported on: Tuesday, November 18, 1997

Fiold ID: S10-1 (upper)

Lab ID: $9711092-9$
Sampie Matrix: solid

\% Moisture: 4.9

Cleanup Method: NONE

Report Basis: DRY WEIGHT
Date Collected: 29-Oct-97

Date Extracted: 11-Nov-97

Date Anatyzed: 14-Nov-97

Prep Batch: sv11092
Sample Aliquot: . $\quad 30$

Final Volume:

Ditution: 2

\begin{tabular}{|c|c|c|c|c|c|c|}
\hline CASNO & Target Analyte & Result & Units & $\begin{array}{c}\text { Reporting } \\
\text { Limit }\end{array}$ & $\begin{array}{l}\text { Result } \\
\text { Qualifier }\end{array}$ & $\begin{array}{c}\text { Result } \\
\text { Footnote }\end{array}$ \\
\hline $110-86-1$ & PYRIDINE & $700 i$ & $u g / \mathrm{kg}$ & 700 & $u$ & \\
\hline $62-75-9$ & N-NITROSODIMETHYLAMINE & $700 !$ & ug/kg & 700 & $\mathrm{u}$ & \\
\hline $62-53-3$ & ANILINE & $1800^{\circ}$ & ug/kg & 1800 & $U$ & \\
\hline $108-95-2$ & PHENOL & $700:$ & $u g / \mathrm{kg}$ & $700:$ & $\mathrm{u}$ & \\
\hline $111-44-4$ & BIS(2-CHLOROETHYL)ETHER & $700 \mathrm{i}$ & ug/kg & $700 !$ & $\mathrm{U}$ & \\
\hline $95-57-8$ & 2-CHLOROPHENOL & 7001 & $u g / \mathrm{kg}$ & $700 i$ & $u$ & \\
\hline 541-73-1 & 1,3-DICHLOROBENZENE & $700 \mathrm{i}$ & $u g / k g$ & 700 & $u$ & \\
\hline $106-46-7$ & 1.4DICHLOROBENZENE & $700:$ & $u g / \mathrm{kg}$ & $700 \mathrm{i}$ & $u$ & \\
\hline $95-50-1$ & 1.2-DICHLOROBENZENE & $700 !$ & ug/kg & 7001 & $\mathrm{u}$ & \\
\hline $100-51-6$ & BENZYL ALCOHOL & 700 & ug/kg & 700 & $\mathbf{u}$ & \\
\hline $108-60-1$ & BIS(2-CHLOROISOPROPYL)ETHER & 7001 & $u g / \mathrm{kg}$ & $700 i$ & $u$ & \\
\hline $95-48-7$ & 2-METHYLPHENOL & $700:$ & ug/kg & $700:$ & $\underline{u}$ & \\
\hline $621-64-7$ & N-NITROSO-DI-N-PROPYLAMINE & 700 & ug/kg & $700 i$ & $u$ & \\
\hline $106-44-5$ & 4-METHYLPHENOL & 7001 & ug $/ \mathrm{kg}$ & 7001 & $u$ & \\
\hline $67-72-1$ & MEXACHLOROETHANE & 700 & ug/kg & $700 !$ & $\underline{u}$ & \\
\hline $98-95-3$ & NITROBENZENE & $700:$ & $\mathrm{ug} / \mathrm{kg}$ & $700 !$ & $\mathrm{U}$ & \\
\hline 78-59-1 & ISOPHORONE & $700 !$ & $\mathrm{ug} / \mathrm{kg}$ & 700 & $u$ & \\
\hline $88-75-5$ & 2-NITROPHENOL & $700 !$ & $u g / \mathrm{kg}$ & $700 !$ & $u$ & \\
\hline $105-67-9$ & 2,4DIMETHYLPHENOL & $700:$ & ug $/ \mathrm{kg}$ & 700 & $u$ & \\
\hline $111-91-1$ & BIS(2-CHLOROETHOXY)METHANE & $700:$ & $u g / \mathrm{kg}$ & $700 !$ & $u$ & \\
\hline $120-83-2$ & 2,4-DICHLOROPHENOL & 700 & $u g / \mathrm{kg}$ & $700 i$ & $\mathrm{u}$ & \\
\hline $65-85-0$ & BENZOIC ACID & $3500:$ & $u g / \mathrm{kg}$ & 3500 & $u$ & \\
\hline $120-82-1$ & 1,2,4-TRICHLOROBENZENE & $700^{\circ}$ & $u g / \mathrm{kg}$ & $700 i$ & $u$ & \\
\hline $91-20-3$ & NAPHTHALENE & $700:$ & $u g / k g$ & 700 & $u$ & \\
\hline $106-47-8$ & 4-CHLOROANILINE & $1800:$ & ug/kg & 1800 & $u$ & \\
\hline $87-68-3$ & HEXACHLOROBUTADIENE & $700 !$ & $u g / \mathrm{kg}$ & 700 & $u$ & \\
\hline $59-50-7$ & 4-CHLORO-3-METHYLPHENOL & $700 i$ & $u g / k g$ & 700 & $u$ & \\
\hline $91-57-6$ & 2-METHYLNAPHTHALENE & $700 !$ & $\mathrm{ug} / \mathrm{kg}$ & 700 & $u$ & \\
\hline $77-47-4$ & HEXACHLOROCYCLOPENTADIENE & 700 & $u g / \mathrm{kg}$ & 700 & $\mathbf{u}$ & \\
\hline $88-06-2$ & 2,4,6-TRICHLOROPHENOL & $700 !$ & $u g / k g$ & 700 & $u$ & \\
\hline $95-95-4$ & 2,4.5-TRICHLOROPHENOL & $700:$ & $\mathrm{ug} / \mathrm{kg}$ & 700 & $u$ & \\
\hline $91-58-7$ & 2-CHLORONAPHTHALENE & 700 & ug/kg - & 700 & $\mathbf{u}$ & \\
\hline $88-74-4$ & 2.NITROANELINE & 3500 & ug/kg & $3500 i$ & $u$ & \\
\hline $131-11-3$ & DIMETHYL PHTHALATE & 700 & $u g / k g$ & $700 i$ & $u$ & \\
\hline
\end{tabular}




\section{Semi-volatile Organics by GC/MS}

\section{Method SW8270}

Lab Name: Paragon Analytics, Inc.

Work Order Number: 9711092

Client Name: Washington State Dept. of Ecol

ClientProject ID: RCRA Closure of 303-K >

Reported on: Tuesday, November 18, 1997

Field ID: \$10-t (upper)

Lab ID: $97 \div 1092-9$
Sample Matrix: solid

$\%$ Moisture: 4.9

Cleanup Method: NONE

Report Basis: DRY WEIGHT
Date Collected: 29-Oct-97

Date Extractod: 11-Nov-97

Date Analyzed: 14-Nov-97

Prep Batch: svi1092
Sample Atiquot: $\quad 30$

Final Volume: 1

Dllution: 2

\begin{tabular}{|c|c|c|c|c|c|}
\hline $606-20-2$ & 2,6-DINITROTOLUENE & 700 & $u g / k g$ & $700:$ & $\mathbf{U}$ \\
\hline $208-96-8$ & ACENAPHTHYYLENE & 700 & ugikg & $700:$ & U \\
\hline $99-09-2$ & 3-NITROANLLINE & 3500 & ug/kg & 3500 & $\mathrm{u}$ \\
\hline $83-32-9$ & ACENAPHTHENE & 700. & ug/kg & 700 : & $U$ \\
\hline $51-28-5$ & 2,4-DINITROPHENOL & $3500^{\prime}$ & $u g / \mathrm{kg}$ & 3500 & $\mathrm{U}$ \\
\hline $100-02-7$ & 4-NITROPHENOL & 3500. & $\mu g / \mathrm{kg}$ & 3500 & $u$ \\
\hline $132-64-9$ & DIBENZOFURAN & 700. & $\mathrm{ug} / \mathrm{kg}$ & $700:$ & $\mathrm{U}$ \\
\hline $121 \cdot 14-2$ & 2.4-DINTROTOLUENE & $700:$ & $u g / \mathrm{kg}$ & $700 !$ & $\mathbf{U}$ \\
\hline $84-66-2$ & DIETHYL PHTHALATE & 700 & ug/kg & $700 !$ & $\mathrm{U}$ \\
\hline $86-73-7$ & FLUORENE & $700:$ & $\operatorname{ug} / \mathrm{kg}$ & $700 i$ & $\mathrm{U}$ \\
\hline $7005-72-3$ & 4-CHLOROPHENYL PHENYL ETHER & 700 & ug/kg & $700 i$ & $u$ \\
\hline $100-01-6$ & 4-NITROANILINE & 3500 & ug $/ \mathrm{kg}$ & 3500 & U \\
\hline $103-33-3$ & AZOBENZENE & 700 & ug/kg & $700 i$ & $\mathrm{U}$ \\
\hline $534-52-1$ & 4.6-DINITRO-2-METHYLPHENOL & 3500 & $\mathrm{ug} / \mathrm{kg}$ & $3500:$ & U \\
\hline $86-30-6$ & N-NITROSODIPHENYLAMINE & 700: & $U g / \mathbf{k g}$ & $700 i$ & $\mathbf{U}$ \\
\hline $101-55-3$ & 4-BROMOPHENYL PHENYL ETHER & 700 & ug/kg & $700 !$ & $u$ \\
\hline $118-74-1$ & HEXACHLOROBENZENE & 700 & $u g / \mathrm{kg}$ & 7001 & $\mathrm{U}$ \\
\hline $87-86-5$ & PENTACHLOROPHENOL & 3500 & ug/kg & $3500:$ & $\mathrm{U}$ \\
\hline $85-01.8$ & PHENANTHRENE & 700 & $u g / k g$ & $700 i$ & $u$ \\
\hline $120 \cdot 12-7$ & ANTHRACENE & 700 & $u g / k g$ & $700 \vdots$ & $\mathrm{U}$ \\
\hline $86-74-8$ & CARBAZOLE & 700 & $\mathrm{ug} / \mathrm{kg}$ & $700 !$ & $\mathbf{U}$ \\
\hline $84-74-2$ & DI-NBEUTYL PHTHALATE & 87 & $u g / \mathrm{kg}$ & $700 i$ & J.B \\
\hline $206-44-0$ & FLUORANTHENE & 700 & ugkg & $700:$ & $\mathbf{u}$ \\
\hline $129-00-0$ & PYRENE & 700 & $u g / \mathrm{kg}$ & $700 i$ & $u$ \\
\hline $85-68-7$ & BUTYL BENZYL PHTHALATE & $700^{\circ}$ & ugfkg & $700:$ & u \\
\hline $56-55-3$ & BENZO(A)ANTHRACENE & 700. & $u g / \mathrm{kg}$ & $700 !$ & U \\
\hline $91-94-1$ & 3.3'-DICHLOROBENZIDINE & $3500:$ & $u g / \mathrm{kg}$ & 3500 & $\mathrm{U}$ \\
\hline $218-01-9$ & CHRYSENE & $700 !$ & $u g / \mathrm{kg}$ & $700:$ & $\mathrm{U}$ \\
\hline $117-81-7$ & BIS(2-ETHYLHEXYL)PHTHALATE & $700^{\circ}$ & $\mathrm{ug} / \mathrm{kg}$ & $700 i$ & $u$ \\
\hline $117-84-0$ & DIN-OCTYL PHTMALATE & $700^{\prime}$ & $\mathrm{ug} / \mathrm{kg}$ & $700:$ & $u$ \\
\hline $205-99-2$ & BENZO(B,K)FLUORANTHENE & $700:$ & $u g / \mathrm{kg}$ & $.700 !$ & $\mathrm{U}$ \\
\hline $50-32-8$ & BENZO(A)PYRENE & 700 & ug $/ \mathrm{kg}$ & $700:$ & $u$ \\
\hline $193-39-5$ & INOENO $(1,2,3-C D)$ PYRENE & $700:$ & $u g / \mathrm{kg}$ & $700 !$ & $U$ \\
\hline $53-70-3$ & DIBENZO(A,H)ANTHRACENE & $700:$ & $u g / \mathrm{kg}$ & $700 i$ & $U$ \\
\hline $191-24-2$ & BENZO(G,H,D)PERYLENE & 700 & $u g / \mathrm{kg}$ & $700 \vdots$ & $U$ \\
\hline
\end{tabular}




\section{Semi-volatile Organics by GC/MS}

\section{Method SW8270}

Lab Name: Paragon Analytics, Inc.

Work Order Number: 9711092

Client Name: Washington State Dept. of Ecot

ClientProject ID: RCRA Closure of 303-K >

Reported on: Tuesday. November 18, 1997

Field ID: S10-1 (upper)

Lab ID: 9711092.9
Sample Matrix: solid

\% Moisture: 4.9

Cleanup Method: NONE

Report Basis: DRY WEIGHT
Date Collected: $29-0 c t-97$

Date Extractod: 11-Nov-97

Date Analyzed: 14-Nov-97

Prep Batch: sv11092 $\begin{array}{rr}\text { Sample Aliquot: } & 30 \\ \text { Final Volume: } & 1 \\ \text { Dilution: } & 2\end{array}$

\section{Surrogate Recovery}

\begin{tabular}{|c|c|c|c|c|c|c|}
\hline CASNO & Surrogate Analyte & Result & Units & $\begin{array}{l}\text { Spike } \\
\text { Amount }\end{array}$ & $\begin{array}{l}\text { Percent } \\
\text { Recovery }\end{array}$ & $\begin{array}{c}\text { Control } \\
\text { Limits }\end{array}$ \\
\hline $118-79-6$ & 2,4,6-TRIBROMOPHENOL & 1910 & ug/kg & 2500 & 76 & $19-113$ \\
\hline $321-60-8$ & 2-FLUOROBIPHENYL & 1160 & ug/kg & 1670 & 70 & $30-105$ \\
\hline $367-12-4$ & 2-FLUOROPHENOL & 1470 & ug/kg & 2500 & 59 & $25-100$ \\
\hline $4165-60-0$ & NITROBENZENE-DS & 1090 & ug/kg & 1670 & 66 & $31-106$ \\
\hline $13127-88-3$ & PHENOL-DS & 1790 & ug/kg & 2500 & 72 & $24 \cdot 104$ \\
\hline $1718-51-0$ & TERPHENYL.D14 & 1830 & ug/kg & 1670 & 110 & $18-112$ \\
\hline
\end{tabular}

$U=$ Less than the Reporting Limit 


\section{Semi-volatile Organics by GC/MS}

\section{Method SW8270}

Lab Name: Paragon Analytics, Inc.

Work Order Number: 9711092

Client Name: Washington State Dept. of Ecot

ClientProject ID: RCRA Closure of 303-K >

Reported on: Tuesday, November 18. 1997

Field ID: S10-2 (lower)

Lab ID: $9711092-10$
Sample Matrix: solid

$\%$ Moisture: 7.8

Cleanup Method: NONE

Report Basis: DRY WEIGHT
Date Collected: $30-0 \mathrm{ct}-97$

Date Extracted: 11-Nov-97

Date Analyzed: 14-Nov-97

Prep Batch: sv11092
Sample Aliquot: 30

Final Volume: 1

Dilution: 2

\begin{tabular}{|c|c|c|c|c|c|c|}
\hline CASNO & Target Analyte & Result & Units & $\begin{array}{c}\text { Reporting } \\
\text { Limit }\end{array}$ & $\begin{array}{l}\text { Result } \\
\text { Qualifier }\end{array}$ & $\begin{array}{l}\text { Result } \\
\text { Footnote }\end{array}$ \\
\hline $110-86-1$ & PYRIDINE & 7201 & $u g / \mathrm{kg}$ & $720 !$ & $\mathbf{U}$ & \\
\hline $62-75-9$ & N-NITROSODIMETHYLAMINE & 720 & $u g / \mathrm{kg}$ & 7201 & U & \\
\hline $62-53-3$ & ANILINE & $1800 !$ & $u g / k g$ & 1800 & $u$ & \\
\hline $108-95-2$ & PHENOL & $720 i$ & $\mathrm{ug} / \mathrm{kg}$ & $720 !$ & $\mathrm{U}$ & \\
\hline $111-44-4$ & BIS(2-CHLOROETHYL)ETHER & $720:$ & ug/kg & $720 !$ & $\mathbf{u}$ & \\
\hline $95-57-8$ & 2.CHLOROPHENOL & 720 & $u g / \mathrm{kg}$ & $720 i$ & U & \\
\hline $541-73-1$ & 1,3-DICHLOROBENZENE & 720 ! & $4 g / \mathrm{kg}$ & 720 & $u$ & \\
\hline $106-46-7$ & 1,4-DICHLOROBENZENE & 720 & $\mathrm{ug} / \mathrm{kg}$ & 720 & U & \\
\hline $95-50-1$ & 1,2-DICHLOROBENZENE & 720 & $u g / \mathrm{kg}$ & 720 & U & \\
\hline $100-51-6$ & BENZYL ALCOHOL & $720 i$ & $\mathrm{ug} / \mathrm{kg}$ & 720 & $\mathrm{U}$ & \\
\hline $108-60-1$ & BIS(2-CHLOROISOPROPYL)ETHER & 720 & ug/kg & 720 & U & \\
\hline $95-48-7$ & 2-METHYLPHENOL & $720 !$ & ug/kg & $720 !$ & $U$ & \\
\hline $621-64-7$ & N-NITROSO-DL-N-PROPYLAMINE & $720 !$ & ug/kg & 7201 & $u$ & \\
\hline $106-44-5$ & 4-METHYLPHENOL & $720 !$ & ug/kg & 720 & U & \\
\hline $67-72-1$ & HEXACHLOROETHANE & $720 !$ & $\mathrm{ug} / \mathrm{kg}$ & 720 & $U$ & \\
\hline $98-95-3$ & NITROBENZENE & 720. & $u g / k g$ & $720 i$ & $U$ & \\
\hline $78-59-1$ & ISOPHORONE & $720:$ & $\mathrm{ug} / \mathrm{kg}$ & $720 !$ & $u$ & \\
\hline $88-75-5$ & 2-NITROPHENOL & $720:$ & $u g / \mathrm{kg}$ & $720 i$ & $U$ & \\
\hline $105-67-9$ & 2,4-DIMETHYLPHENOL & $720 !$ & ug/kg & 7201 & $u$ & \\
\hline $111-91-1$ & BIS(2-CHLOROETHOXY)METHANE & $720 i$ & ug/kg & 720 & U & \\
\hline $120-63-2$ & 2.4-DICHLOROPHENOL & $720 i$ & ug/kg & 720 & $u$ & \\
\hline $65-85-0$ & BENZOIC ACID & $3600 !$ & $u g / \mathrm{kg}$ & 3600 & $\mathrm{U}$ & \\
\hline $120-82-1$ & 1.2.4-TRICHLOROBENZENE & 7201 & $u g / \mathrm{kg}$ & $720 i$ & $\mathbf{u}$ & \\
\hline $91-20-3$ & NAPHTR:ALENE & 7201 & ug/kg & $720 !$ & U & \\
\hline $106-47-8$ & 4-CHLOROANILINE & $1800 !$ & $u g / \mathrm{kg}$ & 1800 & $\mathbf{u}$ & \\
\hline $87-68-3$ & HEXACHLOROBUTADIENE & $720 !$ & ug/kg & 7201 & U & \\
\hline $59-50-7$ & 4-CHLORO-3-METHYLPHENOL & $720 i$ & ug/kg & 7201 & $\mathbf{u}$ & \\
\hline $91.57-6$ & 2-METHYENAPHTHALENE & $720 \mathrm{r}$ & ug/kg & 7201 & $\mathbf{U}$ & \\
\hline $77-47-4$ & HEXACHLOROCYCLOPENTADIENE & $720 !$ & ug/kg & 720 & $u$ & \\
\hline $88-06-2$ & 2.4.6-TRICHLOROPHENOL & $720:$ & $u g / \mathrm{kg}$ & 720 & $\mathbf{U}$ & \\
\hline $95-95-4$ & 2,4,5-TRICHLOROPHENOL & $720 i$ & ug/kg & 720 & U & \\
\hline $91-58-7$ & 2-CHLORONAPHTHALENE & $720:$ & $\mathrm{ug} / \mathrm{kg} \cdot$ & 720 & $\mathrm{U}$ & \\
\hline $88-74-4$ & 2-NITROANILINE & 36001 & $u g / k g$ & 3600 & $\mathbf{u}$ & \\
\hline $131-11-3$ & DIMETHYL PHTHALATE & 720 & $u g / k g$ & $720 i$ & $u$ & \\
\hline
\end{tabular}




\section{Semi-volatile Organics by GC/MS}

\section{Method SW8270}

Lab Name: Paragon Analytics, Inc.

Work Order Number: 9711092

Client Name: Washington State Dept. of Ecol

ClientProject ID: RCRA Closure of 303-K >

Reported on: Tuesday, Novemiet 18, 1997

Fieid ID: \$10-2 (lower)

Lab JD: $9711092-10$
Sample Matrix: solid

$\%$ Molsture: 7.8

Cleanup Method: NONE Report Basis: DRY WEIGHT
Date Collected: $30-0 \mathrm{ct}-97$

Date Extracted: 11-Nov-97

Date Analyzed: 14-Nov-97

Prop Batch: sv1 to92
Sample Aliquot: $\quad 30$

Final Volume:

Dilution: 2

\begin{tabular}{|c|c|c|c|c|c|}
\hline $606-20-2$ & 2,6-DINITROTOLUENE & 720 i & ugikg & $720 i$ & $\mathbf{u}$ \\
\hline $208-96-8$ & ACENAPHTHYLENE & 720 & ug/kg & $720 !$ & $U$ \\
\hline $99-09-2$ & 3-NITROANILINE & $3600 !$ & ugfikg & 3600 & $\mathbf{u}$ \\
\hline $83-32-9$ & ACENAPHTHENE & $720 i$ & ug/kg & $720 !$ & $\mathbf{U}$ \\
\hline $51-28-5$ & 2,4-DINITROPHENOL & 3600 ! & ug/kg & $3600 !$ & U \\
\hline $100-02-7$ & 4-NITROPHENOL & 3600 : & ug/kg & $3600 i$ & $u$ \\
\hline $132-64-9$ & DIBENZOFURAN & $720:$ & $u g / k g$ & 720 & $\mathrm{U}$ \\
\hline $121-14-2$ & 2,4-DINITROTOLUENE & $720 i$ & $u g / \mathrm{kg}$ & 720 & $U$ \\
\hline $84-66-2$ & DIETHYL PHTHALATE & $720:$ & $u g / \mathbf{k g}$ & 720 & $\mathbf{U}$ \\
\hline $86-73-7$ & FLUORENE & $720 !$ & $\mu g / \mathrm{kg}$ & 720 & $u$ \\
\hline $7005-72-3$ & 4-CHLOROPHENYL PHENYL ETHER & $720 !$ & $u g / k g$ & 720 & $\mathrm{U}$ \\
\hline $100-01-6$ & 4-NITROANILINE & 36001 & $u g / \mathrm{kg}$ & 3600 & $u$ \\
\hline $103-33-3$ & AZOBENZENE & $720 i$ & ug/kg & 720 & $u$ \\
\hline $534-52-1$ & 4,6-DINITRO-2AETHYLPHENOL & 3600 : & $\mathrm{tg} / \mathrm{kg}$ & 3600 & $u$ \\
\hline $86-30-6$ & N-NHTROSODIPHENYLAMINE & $720 i$ & ug/ $/ \mathrm{kg}$ & 720 & $\underline{U}$ \\
\hline $101-55-3$ & 4-BROMOPHENYL PHENYL ETHER & $720 i$ & $\mathrm{tug} / \mathrm{kg}$ & 720 & $u$ \\
\hline $118 \cdot 74-1$ & HEXACHLOROBENZENE & $720 !$ & $\mathrm{ug} / \mathrm{kg}$ & 720 & $\underline{u}$ \\
\hline $87-86-5$ & PENTACHLOROPHENOL & $3600 !$ & ug/kg & 3600 & $u$ \\
\hline $85-01-8$ & PHENANTHRENE & $720:$ & $u g / \mathrm{kg}$ & 720 & $U$ \\
\hline $120-12-7$ & ANTHRACENE & $720:$ & $\operatorname{ug} \mathrm{kg}$ & 720 & $\mathbf{u}$ \\
\hline $86-74-8$ & CARBAZOLE & 7201 & $\omega g / k g$ & 720 & $\mathrm{u}$ \\
\hline $84-74-2$ & DI-N-BUTYL PHTHALATE & 87 & ug/kg & 720 & J.B \\
\hline $206-44-0$ & FLUORANTHENE & $720:$ & $\mathrm{ug} / \mathrm{kg}$ & 720 & $\mathbf{u}$ \\
\hline $129-00-0$ & PYRENE & 720 & $u g / \mathrm{kg}$ & 720 & U \\
\hline $85-68-7$ & BUTYL BENZYYL PHTHALATE & 720 & $u g / \mathrm{kg}$ & 720 & $\mathbf{U}$ \\
\hline $56-55-3$ & BENZO(A)ANTHRACENE & $720 !$ & $\omega g / \mathrm{kg}$ & 720 & u \\
\hline $91-94-1$ & 3.3'-DICHLOROBENZIDINE & 3600 ! & $\mathrm{ug} / \mathrm{kg}$ & 3600 & $\mathrm{U}$ \\
\hline $218-01.9$ & CHRYSENE & $720 !$ & $\operatorname{ug} / \mathrm{kg}$ & 720 & $\mathrm{U}$ \\
\hline $117-81-7$ & BIS(2-ETHYLHEXYL)PHTHALATE & $720 i$ & ug/kg & 720 & $\mathbf{u}$ \\
\hline $117-84-0$ & DI-N-OCTYL PHTHALATE & $720:$ & $\operatorname{ug} / \mathrm{kg}$ & 720 & U \\
\hline $205-99-2$ & BENZO(B,K)FLLOORANTHENE & $720 i$ & $\mathrm{ug} / \mathrm{kg}$ & 720 & $u$ \\
\hline $50-32-8$ & BENZO(A)PYRENE & $720 !$ & ug $/ \mathrm{kg}$ & 720 & $\mathrm{U}$ \\
\hline $193-39-5$ & INDENO $(1,2,3-C D)$ PYRENE & $720 !$ & $u g / \mathrm{kg}$ & 720 & $U$ \\
\hline $53-70-3$ & DIBENZO(A,H)ANTHRACENE & 720 & ug/kg . & 720 & $U$ \\
\hline $191-24-2$ & BENZO(G.H.J)PERYLENE & $720 !$ & $u g / k g$ & 720 & $u$ \\
\hline
\end{tabular}




\section{Semi-volatile Organics by GC/MS}

\section{Method SW8270}

Lab Name: Paragon Analytics, Inc:

Work Order Number: 9711092

Client Name: Washington State Dept. of Ecol

ClientProject ID: RCRA Closure of 303-K >

Roported on: Tuesday, November 18, 1997

Fiold 10: S10-2 (lower)

Lab ID: 9711092-10
Sample Matrix: solid

$\%$ Moisture: 7.8

Cleanup Method: NONE

Report Basis: DRY WEIGHT
Date Collected: $30-0 \mathrm{Ct}-97$

Date Extracted: 11-Nov-97

Date Analyzed: 14-Nov-97

Prep Batch: svi1092
Sample Aliquot:

Final Volume:

Dilution:
30

1

2

\section{Surrogate Recovery}

\begin{tabular}{|c|c|c|c|c|c|c|}
\hline CASNO & Surrogate Analyte & Result & Units & $\begin{array}{l}\text { Spike } \\
\text { Amount }\end{array}$ & $\begin{array}{l}\text { Percent } \\
\text { Recovery }\end{array}$ & $\begin{array}{c}\text { Control } \\
\text { Limits }\end{array}$ \\
\hline $118-79-6$ & 2,4,6-TRIBROMOPHENOL & 1860 & $u g / \mathrm{kg}$ & 2500 & 74 & $19-113$ \\
\hline $321-60-8$ & 2.FLUOROBIPHENYL & 1160 & $u g / k g$ & 1670 & 70 & $30-105$ \\
\hline $367-12-4$ & 2-FLUOROPHENOL & 1590 & ug/kg & 2500 & 64 & $25-100$ \\
\hline $4165-60-0$ & NITROBENZENE-D5 & 1080 & ug/kg & 1670 & 65 & $3 t-105$ \\
\hline $13127-88-3$ & PHENOL-D5 & $\uparrow 850$ & $u g / \mathrm{kg}$ & 2500 & 74 & $24-104$ \\
\hline $1718-51-0$ & TERPHENYL-D14 & 1970 & $u g / \mathrm{kg}$ & 1670 & 118 & $18 \cdot 112$ \\
\hline
\end{tabular}

$U=$ Less than the Reporting Limit 
Lab Name: Paragon Analytics, Inc.

Work Order Number: 9711092

Client Name: Washington State Dept. of Ecol

ClientProject ID: RCRA Closure of 303-K >

Reported on: Tuesday, November 18, 1997

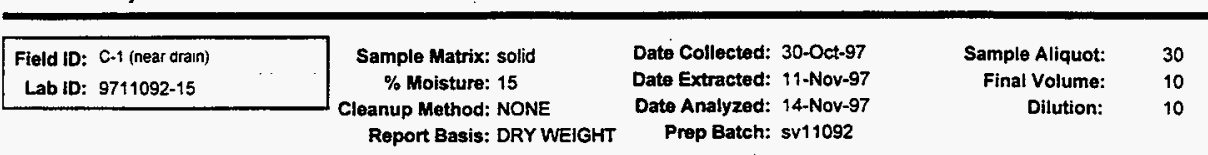

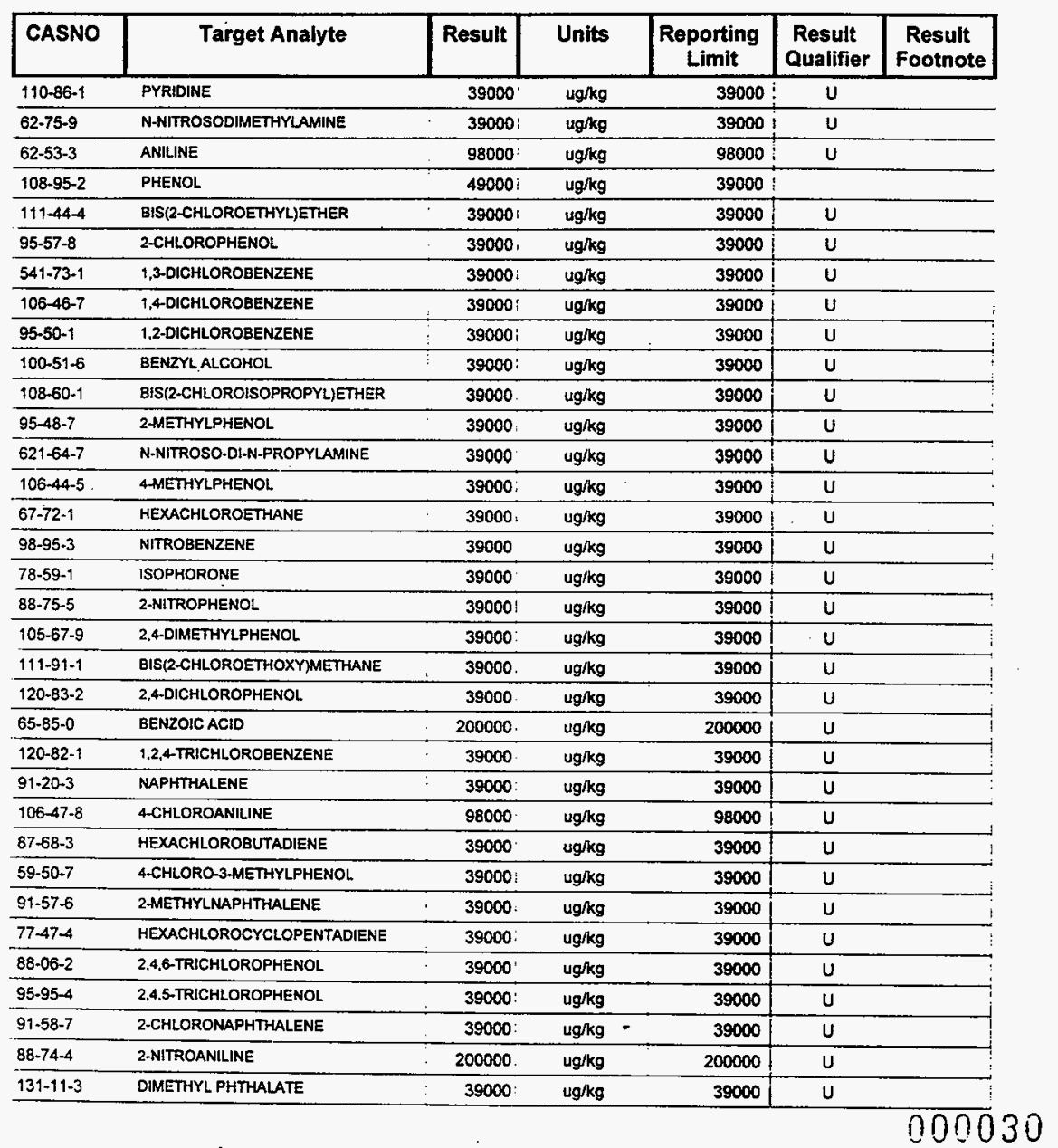




\section{Semi-volatile Organics by GC/MS}

\section{Method SW8270}

Lab Name: Paragon Analytics, Inc.

Work Order Number: 9711092

Client Name: Washington State Dept. of Ecol

ClientProject ID: RCRA Closure of 303-K >

Reported on: Tuesday, November 18, 1997

Field 1D: C-1 (near drain)

Lab ID: 9711092-15
Sample Matrix: solic

\% Moisture: 15

Cleanup Method: NONE

Report Basis: DRY WEIGHT
Date Collected: $30-0 \mathrm{ct}-97$

Date Extractod: 11-Nov-97

Date Analyzed: 14-Nov-97

Prep Batch: sv11092
Sample Aliquot: $\quad 30$

Final Volume: $\quad 10$

Dilution: $\quad 10$

\begin{tabular}{|c|c|c|c|c|c|c|}
\hline $606-20-2$ & 2.6-DINITROTOLUENE & 39000 & ug/kg & 39000 & $\mathbf{U}$ & \\
\hline $208-96-8$ & ACENAPHTHYLENE & 39000 & $\mathrm{ug} / \mathrm{kg}$ & 39000 & $\mathrm{u}$ & \\
\hline $99-09-2$ & 3-NITROANILINE & 200000 & $u g / k g$ & 200000 & $\mathbf{u}$ & \\
\hline $83-32-9$ & ACENAPHTHENE & 39000 & ug/kg & 39000 & $\mathbf{U}$ & \\
\hline $51-28-5$ & 2.4-DINITROPHENOL & 200000 & $u g / \mathrm{kg}$ & 200000: & $\mathbf{U}$ & \\
\hline $100-02-7$ & 4-NITROPHENOL & 200000 & $u g / \mathrm{kg}$ & 200000 & $\mathbf{u}$ & \\
\hline $132-64-9$ & DIBENZOFURAN & 39000 & $u g / k g$ & 39000 & $u$ & \\
\hline $121-14-2$ & 2.4-DINITROTOLUENE & 39000 & Ug/kg & 39000 & $\mathrm{U}$ & \\
\hline $84-66-2$ & DIETHYL PHTHALATE & 39000 & $u g / k g$ & 39000 & $u$ & \\
\hline $86-73-7$ & FLUORENE & 39000 & $u g / k g$ & 39000 & $u$ & \\
\hline $7005-72-3$ & 4-CHLORORHENYL PHENYL ETHER & 39000 & $4 g / \mathrm{kg}$ & 39000 & $\mathbf{u}$ & \\
\hline $100-01-6$ & 4-NITROANILINE & 200000 & $u g / k g$ & 200000 & $\mathbf{U}$ & \\
\hline $103-33-3$ & AZOBENZENE & 39000 & ug/kg & $39000 i$ & $\mathrm{u}$ & \\
\hline $534-62-1$ & 4.6-DINITRO-2+METHYLPHENOL & 200000 & $\mathrm{ug} / \mathrm{kg}$ & 200000 & $\mathrm{U}$ & \\
\hline $86-30-6$ & N-NITROSODIPHENYLAMINE & 39000 & ug/kg & 39000 & $\mathrm{U}$ & \\
\hline $101-55-3$ & 4-BROMOPHENYL PHENYL ETHER & 39000 & ug/kg. & 39000 & $\mathrm{u}$ & \\
\hline $118-74-1$ & HEXACHLOROBENZENE & 39000 & $u g / \mathrm{kg}$ & 39000 & $U$ & : \\
\hline $87-86-5$ & PENTACHLOROPHENOL & 200000 & $u g / k g$ & 200000 & U & \\
\hline $85-01-8$ & PHENANTHRENE & 4600 & $u g / k g$ & $39000 !$ & $\mathrm{J}$ & 1 \\
\hline $120-12-7$ & ANTHRACENE & 39000 & $u g / k g$ & 39000 & $\mathrm{u}$ & \\
\hline $86.74-8$ & CARBAZOLE & 39000 & ug/kg & 39000 & $\mathrm{u}$ & i \\
\hline $84-74-2$ & DI-N-BUTYL PHTHALATE & 39000 & $u g / \mathrm{kg}$ & 39000 & $\mathbf{u}$ & \\
\hline $206-44-0$ & FLUORANTHENE & 39000 & $u g / \mathrm{kg}$ & 39000 & $\mathrm{U}$ & \\
\hline $129-00-0$ & PYRENE & 39000 & ug/kg & 39000 & $\mathrm{U}$ & \\
\hline $85-68-7$ & BUTYL BENZYL PHTHALATE & 39000 & $\mathrm{ug} / \mathrm{kg}$ & 39000 & $u$ & \\
\hline $56-55-3$ & BENZO(A)ANTTHRACENE & 39000 & ug/kg & 39000 & $\mathrm{U}$ & : \\
\hline $91-94-1$ & 3.3'DICHLOROBENZIDINE & 200000 & ug/kg & 200000 & $\mathrm{u}$ & $!$ \\
\hline $218-01-9$ & CHRYSENE & 39000 & $u g / \mathrm{kg}$ & 39000 & $U$ & $\vdots$ \\
\hline $117-81-7$ & BIS(2-ETHYLHEXYL)PHTHALATE & 13000 & ug/kg & 39000 & $\mathrm{~J}$ & \\
\hline $117-84-0$ & DI-N-OCTYL PHTHALATE & 39000 & ug/kg & 39000 & $\mathbf{U}$ & \\
\hline $205-99-2$ & BENZO(B,K)FLUORANTHENE & 39000 & $u g / \mathrm{kg}$ & 39000 & $\mathbf{U}$ & 1 \\
\hline $50-32-8$ & BENZO(A)PYRENE & 39000 & $u g / k g$ & 39000 & $\mathbf{u}$ & \\
\hline $193-39-5$ & INDENO(9,2,3-CD)PYRENE & 39000 & $u g / \mathrm{kg}$ & 39000 & $\mathrm{U}$ & \\
\hline $53-70-3$ & DIBENZO(A.H)ANTHRACENE & 39000 & ug/kg. & 39000 & $\mathbf{u}$ & \\
\hline $191-24-2$ & BENZO(G,H, $)$ PERYLENE & 39000 & ug/kg & 39000 & $\mathrm{U}$ & $i$ \\
\hline
\end{tabular}




\section{Semi-volatile Organics by GC/MS}

\section{Method SW8270}

Lab Name: Paragon Analytics, Inc.

Work Order Number: 9711092

Client Name: Washington State Dept. of Ecol

ClientProject ID: RCRA Closure of 303-K >

Reported on: Tuesday, November 18, 1997

Field ID: C-1 (near drain)

Lab ID: 9711092-15
Sample Matrix: solid

\% Moisture: 15

Cleanup Method: NONE

Report Basis: DRY WEIGFT
Date Collectod: $30-0 c t-97$

Date Extractod: 11-Nov-97

Date Analyzed: 14-Nov-97

Prep Bateh: sv1 t092

\section{Sample Aliquot: $\quad 30$ \\ Final Volume: $\quad 10$ \\ Dilution: 10}

\section{Surrogate Recovery}

\begin{tabular}{|c|c|c|c|c|c|c|}
\hline CASNO & Surrogate Analyte & Result & Units & $\begin{array}{l}\text { Spike } \\
\text { Amount }\end{array}$ & $\begin{array}{l}\text { Percent } \\
\text { Recovery }\end{array}$ & $\begin{array}{c}\text { Control } \\
\text { Limits }\end{array}$ \\
\hline $118-79-6$ & 2,4,6-TRIBROMOPHENOL & 10400 & $u g / k g$ & 25000 & 42 & $19-113$ \\
\hline $321-60-8$ & 2-FLUOROBIPHENYL & 12300 & ug/kg & 16700 & 74 & $30-105$ \\
\hline $367-12-4$ & 2.FLUOROPHENOL & 17800 & ug/kg & 25000 & 71 & $25 \cdot 100$ \\
\hline $4165-60-0$ & NITROBENZENE-D5 & 13500 & $u g / \mathrm{kg}$ & 16700 & 81 & $31-106$ \\
\hline $13927-88-3$ & PHENOL-DS & 21200 & ug/kg & 25000 & 85 & $24-104$ \\
\hline $1718-51-0$ & TERPHENYL-D14 & 18300 & ug/kg & 16700 & 110 & $18-112$ \\
\hline
\end{tabular}

$U=$ Less than the Reporting Limit 


\section{Semi-volatile Organics by GC/MS}

\section{Method SW8270}

Lab Name: Paragon Analytics, Inc.

Work Order Number: 9711092

Client Name: Washington State Dept. of Ecol

ClientProject ID: RCRA Closure of 303-K >

Reported on: Tuesday, November 18, 1997

Field tD: 54

Lab ID: $97 \$ 1092-18$
Sample Matrix: solid

\% Moisture: 3.9

Cleanup Method: NONE

Report Basis: DRY WEIGHT
Date Collected: $29-$ Oct-97

Date Extracted: 11-Nov-97

Date Analyzed: 14-Nov-97

Prep Batch: sv11092
Sample Aliquot: 30

Final Volume: $\quad 1$

Dilution: $\quad 2$

\begin{tabular}{|c|c|c|c|c|c|c|}
\hline CASNO & Target Analyte & Result & Units & $\begin{array}{c}\text { Reporting } \\
\text { Limit }\end{array}$ & $\begin{array}{l}\text { Result } \\
\text { Qualifier }\end{array}$ & $\begin{array}{l}\text { Result } \\
\text { Footnote }\end{array}$ \\
\hline $110-86-1$ & PYRIDINE & 690 & ug/kg & 690 & $\mathrm{U}$ & \\
\hline $62-75-9$ & N-NITROSODIMETHYLAMINE & 690 & $u g / k g$ & 690 & $U$ & \\
\hline $62-53-3$ & ANILINE & 1700 & ug/kg & 1700 & U & \\
\hline $108-95-2$ & PHENOL & 690 & ug/kg & 690 & $U$ & . \\
\hline $111-44-4$ & BIS(2-CHLOROETHYL)ETHER & 690 & $\mathrm{ug} / \mathrm{kg}$ & 690 & $\mathrm{U}$ & \\
\hline $95-57-8$ & 2-CHLOROPHENOL & 690 & $u g / \mathrm{kg}$ & 690 : & $U$ & \\
\hline $541-73-1$ & 1,3-DICHLOROBENZENE & 690. & ug $/ \mathrm{kg}$ & 690 : & $U$ & \\
\hline $106-46-7$ & 1,4-DICHLOROBENZENE & 690 & ug/kg & 690 : & $u$ & \\
\hline $95-50-1$ & 1,2-DICHLOROBENZENE & 690. & ug/kg & 690 & $u$ & \\
\hline $100-51-6$ & BENZYL ALCOHOL & 690 & $u g / \mathrm{kg}$ & 690 & $\mathrm{u}$ & \\
\hline $108-60-1$ & BIS(2-CHLOROISOPROPYL)ETHER & 690 & ug/kg & 690 & $\mathrm{U}$ & \\
\hline $95-48-7$ & 2-METHYLPHENOL & 690 & $u g / \mathrm{kg}$ & 690 & $u$ & \\
\hline $621-64 \cdot 7$ & N-NITROSO-DI-NFROPYLAMINE & 690 & $u g / \mathrm{kg}$ & 690 : & $u$ & \\
\hline $106-44-5$ & 4-METHYLPHENOL & 690 & $u g / \mathrm{kg}$ & $690:$ & $\mathbf{U}$ & \\
\hline $67-72-1$ & HEXACHLOROETHANE & 690 & $\mathrm{ug} / \mathrm{kg}$ & $690:$ & $\mathbf{U}$ & \\
\hline $98-95-3$ & NITROBENZENE & 690 & $u g / \mathrm{kg}$ & $690:$ & $u$ & \\
\hline $78-59-1$ & ISOPHORONE & 690 & $\mathrm{ig} / \mathrm{kg}$ & 690 & $\mathrm{U}$ & \\
\hline $88-75-5$ & 2-NITROPHENOL & 690 & $\Delta g / \mathrm{kg}$ & $690:$ & $\mathrm{U}$ & \\
\hline $105-67-9$ & 2,4-DIMETHYLPHENOL & 690 & $\mathrm{ug} / \mathrm{kg}$ & $690:$ & $\mathrm{U}$ & \\
\hline $111-91-1$ & BIS(2-CHLOROETHOXY)METHANE & 690 & $u g / \mathrm{kg}$ & $690 i$ & $\mathbf{U}$ & \\
\hline $120-83-2$ & 2,4-DICHLOROPHENOL & 690 & $u g / k g$ & $690 i$ & $\mathrm{U}$ & \\
\hline $65-85-0$ & BENZOIC ACID & 3500 & $\mathrm{ug} / \mathrm{kg}$ & 3500 & $\mathrm{U}$ & \\
\hline $120-82-1$ & 1.2,4-TRICHLOROBENZENE & 690 . & ug/kg & $690:$ & $\mathrm{u}$ & \\
\hline $91-20-3$ & NAPHTHALENE & 690 & $\mathrm{ug} / \mathrm{kg}$ & 6901 & $\mathrm{U}$ & \\
\hline $106-47-8$ & 4-CHLOROANILINE & 1700 & $u g / \mathrm{kg}$ & 1700 & $\mathrm{U}$ & \\
\hline $87-68-3$ & HEXACHLOROBUTAOIENE & 690 & ug/kg & 690 & $U$ & \\
\hline $59-50-7$ & 4-CHLORO-3-METHYLPHENOL & 690 & ug/kg & $690 i$ & $U$ & \\
\hline $91-57-6$ & 2-METHYLNAPHTHALENE & 690 & $u g / \mathrm{kg}$ & $690:$ & $\mathrm{U}$ & \\
\hline $77-47-4$ & HEXACKLOROCYCLOPENTADIENE & 690 . & ug/kg & 690 & $\mathrm{U}$ & \\
\hline $88-06-2$ & 2,4,6-TRICHLOROPHENOL. & 690. & $u g / k g$ & $690 !$ & $\mathrm{U}$ & \\
\hline $95-95-4$ & 2,4,5-TRICHLOROPHENOL & 690 & $u g / k g$ & 6901 & $u$ & \\
\hline $91-58-7$ & 2-CHLORONAPHTHALENE & 690 & $\mathrm{ug} / \mathrm{kg}-$ & $690 \vdots$ & $\mathrm{u}$ & \\
\hline $88-74-4$ & 2-NITROANILINE & 3500 & ug/kg & 3500 & $\mathrm{U}$ & \\
\hline $13 \%-11-3$ & DIMETHYL PHTHALATE & 690 & $u g / \mathrm{kg}$ & $690 i$ & $\mathrm{u}$ & \\
\hline
\end{tabular}




\section{Semi-volatile Organics by GC/MS}

\section{Method SW8270}

Lab Name: Paragon Analytics, Inc.

Work Order Number: 9711092

Client Name: Washington State Dept. of Ecol

ClientProject ID: RCRA Closure of 303-K >

Reported on: Tuesday, Noveinber 18, 1997

Field ID: \$4

Lab ID: 9711092-18
Sample Matrix: solid

\% Moisture: 3.9

Cleanup Method: NONE

Report Basis: DRY WEIGHT
Date Collected: $29-0 \mathrm{Oc}-97$

Date Extracted: 11-Nov-97

Date Analyzed: 14-Nov-97

Prep Batch: sv11092
Sample Aliquot: $\quad 30$

Final Volume: $\quad 1$

Dilution: 2

\begin{tabular}{|c|c|c|c|c|c|c|}
\hline $606-20-2$ & 2,6-DINITROTOLUENE & 690 & $\mathrm{ug} / \mathrm{kg}$ & $690:$ & $u$ & \\
\hline $208-96-8$ & ACENAPHTHYLENE & 690 & ug/kg & 690 & $U$ & . \\
\hline $99-09-2$ & 3-NITROANILINE & $3500:$ & $u g / \mathrm{kg}$ & $3500 !$ & $U$ & \\
\hline $83-32-9$ & ACENAPHTHENE & 690 : & $u g / k g$ & 690 & $u$ & \\
\hline $51-28-5$ & 2,4-DINITROPHENOL & 3500 & $u g / k g$ & $3500 \div$ & $u$ & \\
\hline $100-02-7$ & 4-NITROPHENOL & 3500 & $u g / \mathrm{kg}$ & 35001 & $U$ & \\
\hline $132-54-9$ & DI8ENZOFURAN & 690 & $u g / k g$ & $690 !$ & $\mathrm{U}$ & \\
\hline $121-14-2$ & 2.4-DINITROTOLUENE & 690 & ug/kg & 690 & $U$ & \\
\hline $84-66-2$ & DIETHYL PHTMALATE & 6901 & $u g / \mathrm{kg}$ & 690 & $U$ & \\
\hline $86-73-7$ & FLUORENE & 690 & $\mathrm{ug} / \mathrm{kg}$ & 690 & $\mathrm{U}$ & \\
\hline $7005-72-3$ & 4CHLOROPHENYL PHENYL ETHER & 5901 & $\mathrm{ug} / \mathrm{kg}$ & 690 ! & $u$ & \\
\hline $100-01-6$ & 4-NITROANILINE & 3500 & ug/kg & 3500 & $\mathbf{U}$ & \\
\hline $103-33-3$ & AZOBENZENE & 6901 & ug/kg & 6901 & $\mathbf{u}$ & ? \\
\hline $534-52-1$ & 4,6-DINITRO-2-METHYLPHENOL & $3500_{i}$ & ug/kg & 3500 & $\mathbf{u}$ & \\
\hline $86 \cdot 30-6$ & N-NITROSODIPHENYLAMINE & 690 & $u g / \mathrm{kg}$ & 690 & $u$ & . \\
\hline $101-55-3$ & 4-BROMOPHENYL PHENYL ETHER & 6901 & ug/kg & 690 & $\mathbf{U}$ & 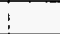 \\
\hline $118-74-1$ & HEXACHLOROBENZENE & 690 & $u g / k g$ & 690 & $\mathbf{U}$ & $i$ \\
\hline $87-86-5$ & PENTACHLOROPHENOL & 3500 & $\mathrm{ug} / \mathrm{kg}$ & 3500 & $u$ & 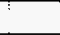 \\
\hline $85-01-8$ & PHENANTHRENE & $690:$ & $\mathrm{ug} / \mathrm{kg}$ & 690 & $\mathrm{U}$ & \\
\hline $120-12-7$ & ANTHRACENE & 690: & $\mathrm{ug} / \mathrm{kg}$ & 690 & $\mathrm{U}$ & ; \\
\hline $86-74-8$ & CARBAZOLE & $690:$ & $u g / \mathrm{kg}$ & 6901 & $\mathbf{U}$ & \\
\hline $84-74-2$ & DI-N-BUTYL PHTHALATE & $110 !$ & $u g / k g$ & 690 & $\mathrm{~J}, \mathbf{B}$ & 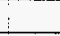 \\
\hline $206-44-0$ & FLUORANTHENE & 6901 & $u g / \mathrm{kg}$ & 690 & $U$ & 1 \\
\hline $129-00-0$ & PYRENE & $690 i$ & ug/kg & 690 & $u$ & \\
\hline $85-68-7$ & BUTYL BENZYL PHTHALATE & $690:$ & ug/kg & 690 & $U$ & 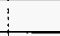 \\
\hline $56-55-3$ & BENZO(A)ANTHRACENE & $690 i$ & ug/kg & 690 & $\mathrm{U}$ & \\
\hline $91-94-1$ & 3,3'-DICHLOROBENZIDINE & $3500 i$ & $u g / k g$ & 3500 & $\mathbf{u}$ & \\
\hline $218-01-9$ & CHRYSENE & $690 !$ & ugg/kg & 690 & $\mathbf{u}$ & \\
\hline $117-81-7$ & BIS(2-ETHYLHEXYL)PHTHALATE & 6901 & ug/kg & 690 & $\mathbf{u}$ & $i$ \\
\hline $117-84-0$ & DI-N-OCTYL PHTHALATE & 6901 & $u g / \mathrm{kg}$ & 690 & $\mathbf{u}$ & \\
\hline $205-99-2$ & BENZO(B.K)FLUORANTHENE & $690 i$ & $u g / \mathrm{kg}$ & 690 & $\mathrm{U}$ & $!$ \\
\hline $50-32-8$ & BENZO(A)PYRENE & $690 i$ & $u g / \mathbf{k g}$ & 690 & $u$ & \\
\hline $193-39-5$ & INDENO(1,2.3-CD)PYRENE & 690 & $u g / \mathrm{kg}$ & 690 & $\mathrm{U}$ & \\
\hline $53-70-3$ & DIBENZO(A,H)ANTHRACENE & $690 i$ & ug/kg - & 690 & $\mathrm{U}$ & \\
\hline $191-24-2$ & BENZO(G,H,I)PERYLENE & $690 !$ & ug/kg & 690 & $u$ & 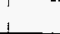 \\
\hline
\end{tabular}




\section{Semi-volatile Organics by GC/MS}

\section{Method SW8270}

Lab Name: Paragon Analytics, inc.

Work Order Number: 9711092

Client Name: Washington State Dept. of Ecot

ClientProject ID: RCRA Closure of 303-K >

Reported on: Tuesday. November 18, 1997

Field ID: $S 4$

Lab 1D: $9711092-18$
Sample Matrix: solid

$\%$ Moisture: 3.9

Cleanup Hethod: NONE

Report Basis: DRY WEIGHT
Date Collected: 29-Oct-97

Date Extracted: 11-Nov-97

Date Analyzed: 14-Nov-97

Prep Batch: \$v11092
Sample Aliquot:

Final Volume:

Dilution:

\section{Surrogate Recovery}

\begin{tabular}{|c|c|c|c|c|c|c|}
\hline CASNO & Surrogate Analyte & Result & Units & $\begin{array}{l}\text { Spike } \\
\text { Amount }\end{array}$ & $\begin{array}{l}\text { Percent } \\
\text { Recovery }\end{array}$ & $\begin{array}{c}\text { Control } \\
\text { Limits }\end{array}$ \\
\hline $118-79-6$ & 2,4,6-TRIBROMOPHENOL & 2160 & ug $/ \mathrm{kg}$ & 2500 & 86 & $19-113$ \\
\hline $321-60-8$ & 2-FLUOROBIPHENYL & 1270 & ug/kg & 1670 & 76 & $30-105$ \\
\hline $367-12-4$ & 2.FLLUOROPHENOL & 1660 & ug/kg & 2500 & 66 & $25-100$ \\
\hline $4165-60-0$ & NITROBENZENE-DS & 1230 & $u g / k g$ & 1670 & 74 & $31-106$ \\
\hline $13127-88-3$ & PHENOL-D5 & 1910 & $\mathrm{ug} / \mathrm{kg}$ & 2500 & 76 & $24-104$ \\
\hline $1718-51-0$ & TERPHENYL-D14 & 1810 & ug $/ \mathrm{kg}$ & 1670 & 109 & $18-112$ \\
\hline
\end{tabular}

$U=$ Less than the Reporting Limit 
HNF-2959

2

FIELD CHANGE AGREEMENT 
HNF-2959

This page intentionally left blank. 
Field changes made to the 303-K Storage Facility Sampling and Analysis Plan (HNF-SD-ENV-AP-005, Revision 0) during the sampling event of October 29 and 30, 1997:

1. Sample location 57 was moved east (about 0.3 meters) from outside the 303-K Storage Facility fence to inside the fence. The original sample location was in the dirt strip between the 303-K fence and the wall of the south half of the 303-K Building. The move was prompted by concerns about possible radiological contamination under the asphalt. This sample location was located outside the fence to access the soil at the edge of the Large Asphalt Pad. No radiological contamination above background was found at this sample location.

2. Sample location S10 was relocated about 0.45 meters south and 0.15 meters east of the original location selected. This sample was relocated due to rain water collecting in the sample hole.

3. The field screening by immunoassay for pentachlorophenol (PCP) was halted after 8 samples. The results were providing inconsistent data. The test kit had minimum detect limits of $1 \mathrm{ppm}, 10 \mathrm{ppm}$, and $100 \mathrm{ppm}$. Examples of the inconsistent results include:

57: No hits at $1 \mathrm{ppm}$ or $10 \mathrm{ppm}$, but positive results at $100 \mathrm{ppm}$.

S6 Duplicate: Hits at $1 \mathrm{ppm}$ and $100 \mathrm{ppm}$ but not hits at $10 \mathrm{ppm}$.

As a result of the inconsistencies, BWHC (J. A. Remaize) and WMH (J. G. AdTer) determined that the test was not providing useful information and that the samples for semi-volatile organic analysis would have to be sent in to the off-site laboratory. At this point field screening was stopped.

4. At sample location $\mathrm{C2}$, due to the large area of concrete that needed to be scabbled, there was insufficient room to collect a duplicate sample from an adjacent location. Therefore, $\mathrm{C2}$ duplicate sample was collected from the same material as the C2 sample. 
FIELD CHANGES TO 303-K STORAGE FACILITY SAMPLING AND ANALYSIS PLAN FOR THE SAMPLING EVENT OF OCTOBER 29 AND 30, 1997

Page 2 of 2

The undersigned indicate by their signatures that these are the field changes made during the above dated sampting event.
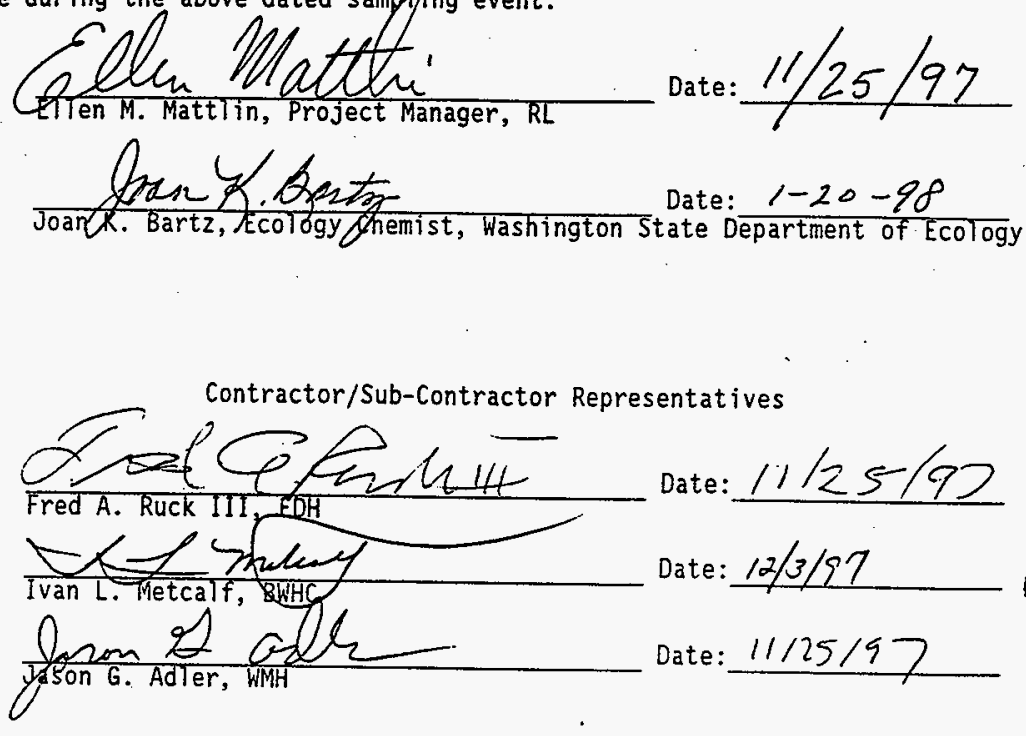
HNF-2959

2

IMMUNOASSAY KIT INSTRUCTIONS 
HNF-2959

1

2

3

4

5

This page intentionally left blank. 


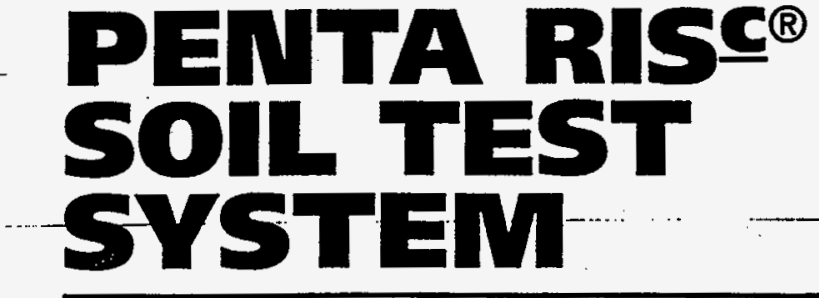

RAPIDUMGUMOASSAY SCREER

\section{User's Guide Multiple Level Test}

in method correctly identifies $95 \%$ of samples containing 0.5 ppm pentachlorophenol (PCP). A sample that develops less color than the standard is interpreted as positive. It contains PCP. A sample that develops more color than the standard is interpreted as negative. It contains less than 0.5 ppm PCP.

\section{IMPORTANT NOTICE}

This test system should be used only under the supervision of a technically qualified individual who is capable of understanding any potential health and environmental risks of this product as identified in the product literature. The components must only be used for the analysis of soil samples for the presence of pentachlorophenol. After use, the kits must be disposed of in accordance with applicable federal and local regulations. 


\section{PENTA RISE SOIL TEST TROUBLESHOOTER GUIDE}

\section{READ ALL INSTRUCTIONS BEFORE PROCEEDING WITH THE TEST}

Wash Step - Lack of vigorous washing may result in false positives or negatives depending on whether the wash error was committed on standard or sample tubes.

Solution: make sure that the operator washes four times vigorously.

Plpot Gallbration - An out-of-calibration pipet may result in false positives or negatives depending on whether the amount is greater or less than the specified transfer volume.

Solution: Check the calibration at least daily and after any extreme mechanical shock (such as dropping). An indication that the pipet is out of calibration is if the gold barrel is loose and will turn. (When set on $30 \mu l$ there should be about $1 / 4$ of an inch between the white plunger and the end of the clear pipet tip.)

Afr bubbles in the pipot - The presence of air bubbles in the pipet tip when transferring extracts may result in false positives or negatives depending on whether the error was committed on standard or sample tubes.

Solution: Quickly examine the pipet tip each time an aliquot is withdrawn and go back to the source and take another aliquot to displace the air bubble if necessary.

Milxing - Lack of thorough mixing, when instructed, can cause inconsistent results.

Solution: Observe the mixing times in the instructions and mix with sufficient force to ensure homogeneity.

Timing - It is important to follow the timing steps in the instructions carefully. The incubation ste in the antibody tubes can vary a bit without harm to the test. The color development step timing is critical and should be no less than 2 minutes and no greater than 3 minutes.

Wiping the Tubes - Wiping of the tubes should be done before they are read in the spectrophotometer because smudges and fingerprints on the tubes can give potentially false negative readings.

Mixing Lot \#'s - Never mix lots! Each kit's components are matched together for optimal performance and may give inaccurate results with the components from other kits. Also, the user must NEVER mix components from different types of kits (ex: Petro kit buffer can't be used with a PCP kit.)

Storage and Operaling Temperatures. - Temperature requirements are very important and should be strictly adhered to. This test kit should be stored at less than $80^{\circ} \mathrm{F} / 27^{\circ} \mathrm{C}$, and operated between $55^{\circ} \mathrm{F} / 13^{\circ} \mathrm{C}$ and $90^{\circ} \mathrm{F} / 32^{\circ} \mathrm{C}$.

Shell Lile - Each kit label contains the kit expiration date. To achieve accurate results, kits must be used prior to expiration. 


\section{READ TO AVOID GOSTLY MISTAKES}

READ ALL INSTRUCTIONS BEFORE PROCEEDING WTH THE TEST

\section{SAMPIE DILUTOK PROGRAH}

1. The sample dilution procedure on page 6 of the instructions is for $0.5,5$, and 50 ppm detection levels. The following diagram represents the sample dilution procedure for all other detection levels

\section{EVERYDILUTION AMPULE PROVIDED MUST BE USED1}

- If there are any questions concerning the dilution procedure please call Technical Services before running the samples to help avoid costly mistakes.

$1-800-242-7472$ or $919-941-5509 . .$. .

EXAMPLE:

Lowest Level Intermediate Level Highest Level
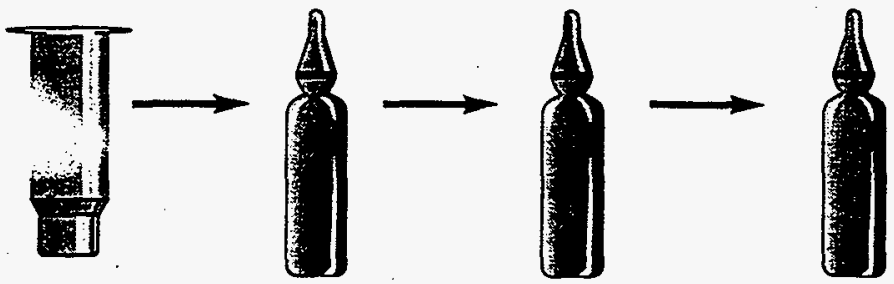

Dilution

Ampules

Note: Always transfer filtered sample to the dilution labeled with the lowest ppm level and then transfer from it to the next higher level dilution.<smiles></smiles>

$100 \mu$

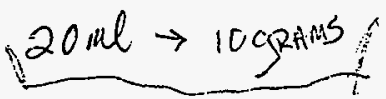




\section{WOBKSTATION SET-UP}

\section{READ ALL INSTRUGTIONS BEFORE PROCEEDING WITH THE TEST}

\section{WORKSTATIOT SETUP FOR I SAMPLE AT 3 LEVELS}

- 2 mincivinat inat tha

- sin savisar

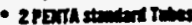

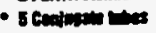

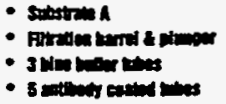

- staris 1

- Irevinat

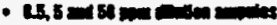

- Bmantina

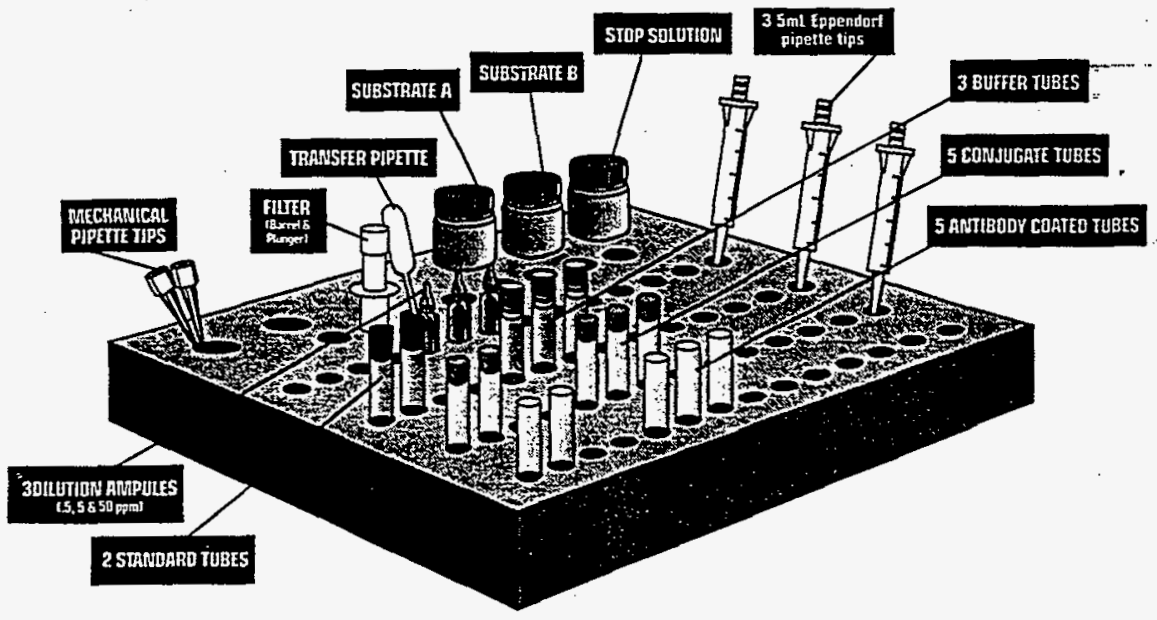

\section{READ BEFORE PROCEEDTHG}

- Follow diagram above to setup workstation.

- Items that you will need that are not provided in the test kit include:

a permanent marking pen, laboratory tissue (or paper towels), a liquid waste container, and disposable gloves.

- This User's Guide was written for analyzing soil samples for PCP at $0.5,5$ and $50 \mathrm{ppm}$.

- Label all Eppendorf tips. Tips can be reused for future analyses. Label the first $5 \mathrm{~mL}$ tip " $A$ ", the second tip " $B$ " \& the third tip "Stop". 


\section{PHASE ONIE}

\section{EXTRACTION \& PREPARATION OF THE SAMPLE}

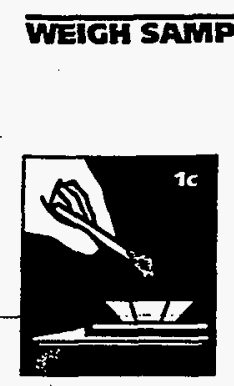

1a Place unused weigh boat on pan balance.

1b Press ON/MEMORY button on pan balance. Balance will beep and display 0.0 .

16 Weigh out $10^{+} /-0.1$ grams of soil.

1d If balance turns off prior to completing weighing, use empty weigh boat to retare, then continue.

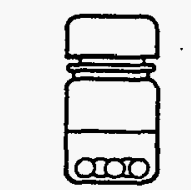

cand stretes da

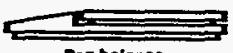

Pan betres

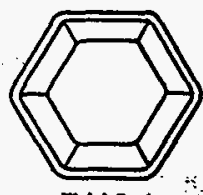

wetren :

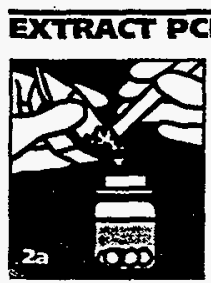

2a Using wooden spatula, transfer 10 grams of soil from weigh boat into extraction jar containing Methanol.

2b Recap extraction jar tightly and shake vigorously for one minute.

2c Allow to settle for one minute. Repeat steps $1 \mathbf{a}-\mathbf{2 c}$ for each sample to be tested.

\section{FILTER SAMPLE}

3a Disassemble filtration plunger from filtration barrel.

3b Insert bulb pipet into top (liquid) layer in extraction jar and draw up sample. Transfer at least $1 / 2$ bulb capacity into filtration barrel. Do not use more than one full bulb.

3c Press plunger firmly into barrel until adequate filtered sample is available (place on table and press if necessary).

Repeat steps 3a - 3c for each sample to be tested.

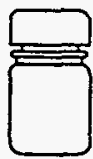

Semple extratten jor

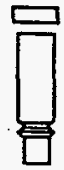

Fitrition Dtenser

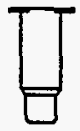

filtuden term!

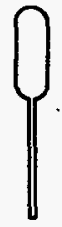

Buis biven 


\section{PHASE TWO}

\section{SAMPLE AND STANDARD PREPARATION}

READ ALL INSTRUCTIONS BEFORE PROCEEDING WITH THE TEST

\section{READ BEFORE PROCEEDING}

- "Shake tubes" means to thoroughly mix the contents with special care not to spill or splash.

DILTh AnW gUFFar SAMPLE

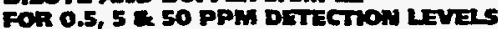

see pere 3 for other detection lewel

4a Flick or tap to get buffer into the bottom of the ampule. Open dilution ampules.

4b Uncap enough conjugate and buffer tubes for sumuls and stanimis.

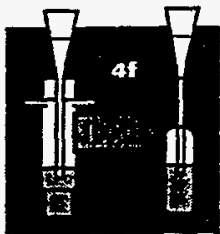

4c Empty two Penta standard tubes into two conjugate tubes.

4d Empty a blue buffer tube into each remaining conjugate tube for samples.

4e Assemble tip onto mechanical pipet.

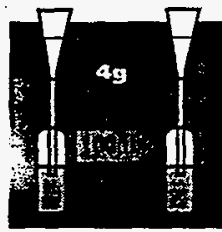

$4 f$ Withdraw $100 \mu \mathrm{L}$ of sample from filter unit using mechanical pipet and dispense below the liquid level in 0.5 om dilution ampule. Shake for 5 seconds. Wipe mechanical pipet tip.

49 Withdraw $100 \mu$ L of diluted sample from $\mathrm{s}$ mom dilution ampule and dispense below the liquid level in the $5 m$ dilution ampule. Shake 5 seconds. Wipe mechanical pipet tip.
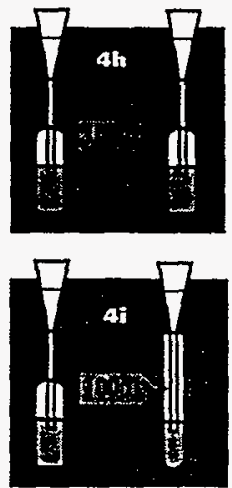

4h Withdraw $100 \mu \mathrm{L}$ of diluted sample from 5 inm dilution ampule and dispense below the liquid level in su dilution ampule. Shake for 5 seconds. Wipe mechanical pipet tip.

$4 i$ Withdraw $100 \mu \mathrm{L}$ of diluted sample from st um dilution ampule and dispense below the liquid level in 30 nom conjugate tube. Repeat with 5 and .5 ppm test levels.

4i Discard mechanical pipet tip.

Repeat steps $4 \mathrm{e}-4 i$ for each sample to be tested.

4k Mix all conjugate tubes for $5 \mathrm{sec}$.
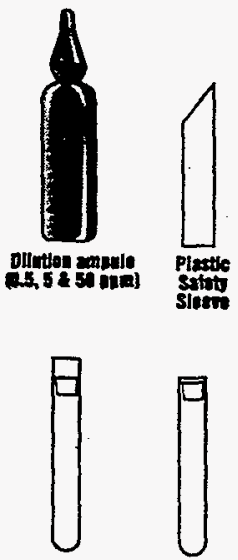

Bius urtiet

Conjusta tubes
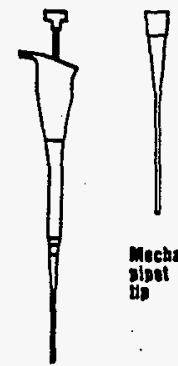

Mnchasleal bleot tis

Mackroteal unat 


\section{PHASE THREE \\ THE IMMUNOASSAY}

READ ALL INSTRUCTIONS BEFORE PROCEEDING WITH THE TEST

\section{TRATSFER FAOM CONUUATE TUBE TO AMTIBODY COATED TUBE}

52. Label the antibody coated tubes with sample identification and test level.

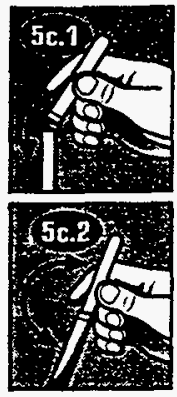

5h. Set timer for 10 minutes.

5c. Working left to right in the workstation:

1. Fit all antibody coated tubes firmly on top of all corresponding conjugate tubes.

2. Start timer and immediately-invert all connected tube pairs so that the liquid is poured into the antibody coated tubes. Return the tube pairs to the appropriate workstation row making sure the (larger) antibody coated tube is on the bottom.

5t. Disconnect and discard the smaller glass conjugate tubes. [It is not important to worry about drops of liquid adhering to lips of tubes].

\section{WASH PROCEDURE}

- Washing must be done vigorously and with force.

- Place nozzle just above antibody coated tube, squeeze bottle to fill each tube with a vigorous stream and empty into liquid waste container.

- The wash solution is a harmless, dilute solution of detergent. Do not hesitate to wash vigorously even if the solution contacts gloved hands.

\section{WASHITIG}
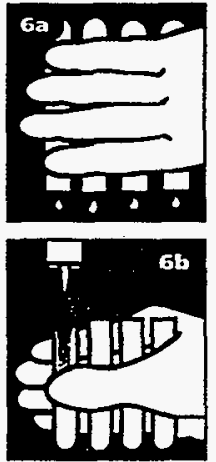

Part 430946 Fey. 1 6a. After the 10 minute incubation period, empty antibody coated tubes into liquid waste container.

6h. Wash antibody coated tubes with wash solution by vigorously filling and emptying a total of 4 times.

6c. Tap antibody coated tubes upside down on paper towels to remove excess liquid. Residual foam in the tubes will not interfere with test results.
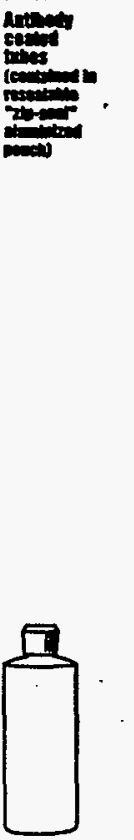

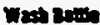




\section{PHASE THREE}

\section{THE IMMUNOASSAY}

7a Set the Eppendorf Repeater on 2 , assemble the " $A$ " tip and fill with Substrate A (TMB, yellow label).

7b Dispense once (200pl) into each antibody coated tube.

7c Set timer for exactly $21 / 2$ minutes

7d Assemble "B" tip, fill with Substrate $\mathrm{B},\left(\mathrm{H}_{2} \mathrm{O}_{2}\right.$, green label) start timer, and dispense once (200pl) into each antibody coated tube.

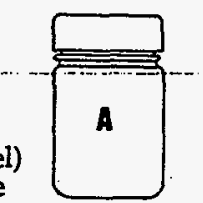

senstrat $A$

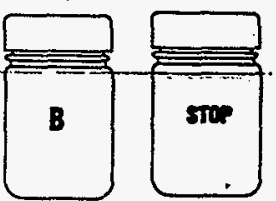

Substrite:

7e Shake all tubes for 5 seconds. Solution will turn blue in some or all antibody coated tubes.

If Assemble "Stop" tip, fill with Stop Solution (red label), and stop reaction at end of $21 / 2$ minutes by dispensing once (200ul) into each antibody coated tube. 


\section{PHASE FOUR}

INTERPRETATION

READ ALL INSTRUCTIONS BEFORE PROCEEDING WIT THE TEST

\section{SELECT CONSERVATTVE STAWDARD}

8a Wipe outside of all antibody coated tubes.

8b Place both simant tubes in photometer.

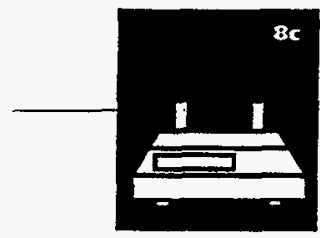

8c Switch tubes until the photometer reading is negative or zero. Record reading. If reading is greater than -0.3 in magnitude, results are outside of QC limits. Retest the sample(s).

Bd Remove and discard tube in right well. The tube in the left well is the conservative standard.

\section{TTERPRET RESULTS}

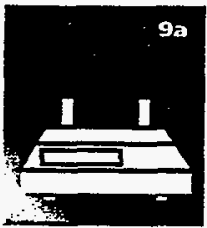

9a Place $\mathbf{1 . 5} \mathrm{pm}$ sample tubes in right well of photometer and record reading.

If photometer reading is negative or zero, PCP is present.

If photometer reading is positive, concentration of PCP is less than $0.5 \mathrm{sm}$.

9h Place 5 mpm tube in right well of photometer and record reading shown on display. If photometer reading is negative or zero, PCP is present.

If photometer reading is positive, concentration of PCP is less than $5 \mathrm{mmm}$.

9c Same as above for $50 \mathrm{ppm}$. 


\section{QUALITY GONTROL}

\section{READ ALL IISTRUCTIONS BEFORE PROCEEDING WTH THE TEST}

\section{How lt Works}

Standinds, Sumples, and color-change reagents are added to test tubes coated with a chemical specific to pentachlorophenol. The concentration of pentachlorophenol in an unknown Sample is determined by comparing its color intensity with that of a Standard.

Note: Pentachlorophenol coneentration is inversely proportional to color intensity; the lighter the color development of the sample, the higher the concentration of pentachlorophenol.

\section{Quality Control}

Standard precautions for maintaining quality control:

- Do not use reagents or test tubes from one Test System with reagents or test tubes from another Test System.

a Do not use the Test System after its expiration date.

- Each analysis must include 2 Standards, with no more than a total of 12 antibody coated tubes.

- Do not exceed incubation periods prescribed by the specific steps.

- Results may not be valid if photometer reading for Standards exceeds 0.3 in magnitude.

\section{Storage and Handling Precautions}

- Wear protective gloves and eyewear.

- Store kit at room temperature and out of direct sunlight (less than $80^{\circ} \mathrm{F}$ ).

- Keep aluminized pouch (containing unused antibody coated tubes) sealed when not in use.

- If liquid from the extraction jar, or PCP Standard comes into contact with eyes, wash thoroughly with cold water and seek immediate medical attention.

- Operate test at temperatures greater than $13^{\circ} \mathrm{C} / 55^{\circ} \mathrm{F}$ and less than $32^{\circ} \mathrm{C} / 90^{\circ} \mathrm{F}$.

- After use, dispose of kit components in accordance with applicable federal and local regulations.

\section{System Description}

Each Penta RISCo Soil Test System contains enough material to perform twelve complete tests, at two different test levels.

The Penta RISco Soil Test is divided into four phasex. The instructions and notes should be reviewed before proceeding with each phase.

\section{Hotline Assistance}

If you need assistance or are missing necesany Test System materials, call toll free: 1-800-242-RISC (7472).

\section{Validation and Warranty Information}

Product clains are based on validation studies carried out under controlled conditions. Data has been collected in accordance with valid statistical methods and the product has undergone quality control tests of each manufactured lot.

Pentachlorophenol free soil and soil containing $0.5 \mathrm{ppm}$ of pentachlorophenol were tested with the EnSys Penta RISco analytical method. The method correctly identified 95\% of these samples.

The company does not guarantee that the resules wit. it Penta RISCO Soil Test System will always agree with instrument-based analytical laboratory methods. Alt analytical methods, both field and laboratory, need to be subject to the appropriate quality control procedures. EnSys, ine. warrants that this product conforms to the descriptions contained herein. No other warranties, whether expressed or implied, including warranties of merchantability and of finess for a particular purpose shall apply to this product.

EnSys, Inc. neither assumes nor authorizes any representative or other person to assume for it any obligation or liability other than such as is expresily set forth herein.

Under no circumstances shall EnSys, Inc be liable for incidental or consequential damages resulting from the use or handling of this product. 


\section{REPEATER PIPET \& MIECHANICAL PIPET}

\section{BEAD ALL INSTRUCTIONS BEFORE PROCEEDING WITH THE TEST}

\section{HOW TO OPERATE} THE REPEATER PIPET

\section{To Set Or Adjust Volume}

To determine the pipetting volume, the dial setting (1-5) is multiplied by the minimum pipetting volume of the tip.

\section{To Assemble Plpet Tip}

Slide filling lever down until it stops. Then raise the locking clamp and insert the tip untirit clicks into position. Be sure the tip plunger is fully inserted into the barrel before lowering the locking clamp to affix the tip in place.

\section{To Fill Tip}

With tip mounted in position on pipet, immerse end of tip into solution. Slide filling lever upward slowly.

\section{To Dispense Sample}

Check the volume selection dial to ensure pipetting volume. Place tip inside test tube so that tip touches the inner wall of tube. Completely depress se pipetting lever.

\section{To Eject Tip}

Empty tip of any remaining solution into appropriate container. Raise locking clamp upward, and remove the tip.

For additional information regarding operation and use of repeater, please refer to your Repeater pipet manual.
Mechanical Pipet

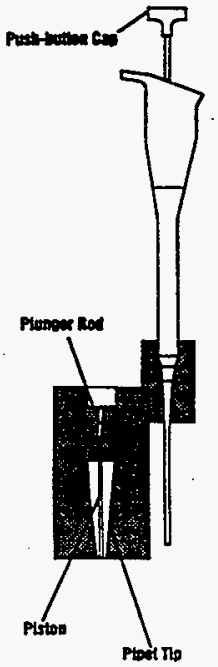

Repeater Pipet

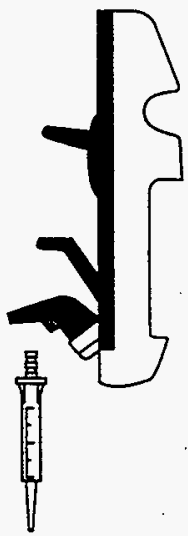

\section{HOM TO OPERATE THE MECIANICAL PIPS:}

\section{To Set Or Adjust Volume}

Remove push-button cap and use it to loosen volume lock screw. Turn lower part of push-button to adjust volume up or down. Meter should read " 100 ". Tighten volume lock screw and replace pushbutton cap.

\section{To Assemble Pipet Tip}

Slide larger mounting end of pipet tip onto end of pipet. Holding tip in place, press push-button until plunger rod enters pipet tip. Ensure no gap exists between piston and plunger rod.

\section{To Withdraw Sample}

With tip mounted in position on pipet, press push-button to first stop and hold it. Place tip at bottom of liquid sample and slowly release push-button to withdraw measured sample. Ensure that no bubbles exist in liquid portion of sample. If bubbles exist, dispense sample and rewithdraw sample.

\section{To Dispense Sample}

Place tip into dispensing vessel (immersing end of the tip if vessel contains liquid) and slowly press pushbutton to first stop. (Do not push to second stop or tip will eject).

Remove tip from vessel and release pushbutton.

\section{To Efect Tip}

Press push-button to second stop. Tip is ejected.

For additional information regarding operation and use of pipet, please refer to your pipet manual. 


\section{ON-SITE QUALITY GONTROLIQUALITY ASSURANCE \\ RECOMMENDATIONS \\ EnSYS RISC® TEST SYSIEM}

Please read the following before proceeding with fleld testing.

\section{SAIIPLIWE}

The result of your screening test is only as valid as the sample that was anatyzed. Samples should be homogenized thoroughly to ensure that the 10 grams you remove for field testing is representative of the sample as a whole. All other applicable sample handling procedures should be followed as well.

\section{PRIOR TO TESTIHE SAMPLES}

Carefully follow the instructions in the User's Guide included with every test kit. This is the key element in obtaining accurate results. In addition, store your unused test kits at room temperature and do not use them past their expiration date (see label on each test kit).

\section{YNAL TEST QC}

Two standards are analyzed with each sample to provide internal test system quality control. With both standards inserted in the photometer, a valid test is indicated when the magnitude of the displayed number (irrespective of the sign, + or -) is less than the value given in the User's Guide. Test runs resulting in a greater number should be repeated to ensure valid conclusions.

\section{QA/QC}

The validity of field test results can be substantially enhanced by employing $a$ modest, but effective $Q A / Q C$ plan. EnSys recommends that you structure your $Q A / Q C$ plan with the elements detailed below. These have been developed based on the data quality principles established by the U.S. Environmental Protection Agency.
A. Sample Documentation
1. Location, depth
2. Time and date of collection and field analysis
B. Fieid analysis documentation - provide raw data, calibration, any calculations, and final results of field analysis for all samples screened (including QC samples)
C. Method calibration - this is an integral part of EnSys RISc\$ immunoassay tests; a duplicate calibration is performed for each set of samples tested (see the instructions in the User's Guide)
D. Method blank - field analyze the contents of an unused extraction jar $x$
E. Site-specific matrix background field analysis - collect and field analyze uncontaminated sample from site matrix to document matrix effect
F. Duplicate sample field analysis - field analyze duplicate sample to document method repeatability;
at least one of every 20 samples should be analyzed in duplicate
G. Confirmation of field analysis - provide confirmation of the quantitation of the analyte via an EPA-approved method different from the field method on at least $10 \%$ of the samples; choose at least two representative samples testing above the action level; provide chain of custody and documentation such as gas chromatograms, mass spectra, etc.
H. Performance evaluation sample field anahysis (optional, but strongly recommended) - field analyze performance evaluation sample daily to document method/operator performance I. Matrix spike field anahysis (optional) - field analyze matrix spike to document matrix effect on analyte measurement

\section{FURTHER QUESTIONS?}

EnSys technical support personnel are always prepared to discuss your quality needs to help you meet your data quality objectives. 
HNF-2959

1 APPENDIX E

2 EQUATIONS USED IN THE STATISTICAL ANALYSIS 
HNF-2959

This page intentionally left blank. 


\section{APPENDIX E}

\section{EQUATIONS USED IN THE STATISTICAL ANALYSIS}

Calculations of the Mean:

$$
\begin{aligned}
& \qquad \bar{x}=\frac{\sum_{i=1}^{n} x_{i}}{n} \\
& \bar{x}=\text { mean } \\
& x_{i}=\text { constituent concentration } \\
& n=\text { number of samples }
\end{aligned}
$$

Calculation of the Standard Deviation:

$$
s=\frac{\sqrt{\sum_{i=1}^{n} x_{i}^{2}-\frac{\left(\sum_{i=1}^{n} x_{i}\right)^{2}}{2}}}{n-1}
$$

$$
\begin{aligned}
& s=\text { standard deviation } \\
& x_{i}=\text { constituent concentration } \\
& n=\text { number of samples }
\end{aligned}
$$

Calculation of the Coefficient of Variation:

$$
\begin{aligned}
& \qquad V=\frac{s}{\bar{x}} \\
& \frac{s}{\bar{x}}=\text { standard deviation } \\
& \qquad \text { mean }
\end{aligned}
$$


Calculation of the Relative Percent Difference:

$$
R P D=\left|100 \frac{x_{\text {orig }}-x_{\text {dupp }}}{\left(\frac{x_{\text {orig }}+x_{\text {dupp }}}{2}\right)}\right|
$$

$R P D=$ Relative Percent Difference

$x_{\text {orig }}=$ concentration of original sample

$x_{d u p}=$ concentration of duplicate sample 


\section{DISTRIBUTION}

U. S. Department of Energy, Richland Operations Office

C. E. Clark

M. R. Hahn

A. B. Joy

E. M. Mattlin

MSIN

A5-15

R3-79

R3-79

A5-15

B\&W Hanford, Inc.

K. A. Hadley

R3-56

I. L. Metcalf

L6-26

D. E. Rasmussen

L1-03

J. A. Remaize

L6-26

Fluor Daniel Hanford, Inc.

W. D. Adair

H6-21

N. A. Ballantyne

N1-26

M. DeLeon

N1-26

A. M. Hopkins

L. J. Olguin

F. A. Ruck III

N1-26

N1-26

H6-22

B. D. Williamson

B3-15

Fiuor Daniel Northwest, Inc.

R.G. Hollenbeck

G3-17

ICF-Kaiser, Inc.

G. M. Clark

R3-77

Waste Management Federal Services of Hanford, Inc.

J. G. Adler

H6-24

R. C. Bowman

H6-24

R. H. Engelmann

H6-26

S. M. Steele

T6-03

J. A. Winterhalder

H6-21

Permitting Documentation

L4-97

Waste Management Federal Services, Inc., Northwest Operations

D. L. Edwards

H1-21

K. J. Young

H1-21

Lockheed Martin Services, Inc.

Central Files

B1-07

DPC

H6-08

EDMC (2)

H6-08 
This page intentionally left blank. 